\title{
Iron-Catalyzed Alkyne Carboamination via an Isolable Iron Imide Complex
}

\author{
Corey A. Richards, ${ }^{a}$ Nigam P. Rath, ${ }^{b}$ and Jamie M. Neely ${ }^{*, a}$ \\ a Department of Chemistry \\ Saint Louis University, Saint Louis, Missouri, 63103, United States \\ ${ }^{b}$ Department of Chemistry and Biochemistry \\ University of Missouri-St. Louis, Saint Louis, Missouri, 63121, United States
}

Supporting Information

\section{Table of Contents}

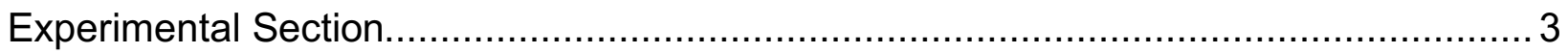

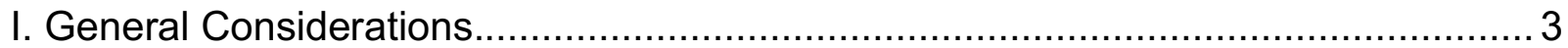

II. Preparation of Iron Complexes................................................................. 5

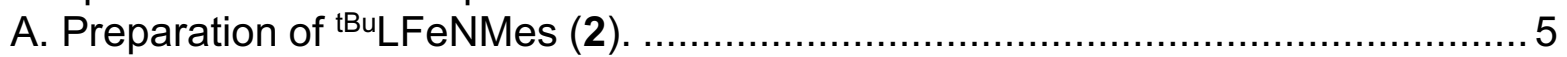

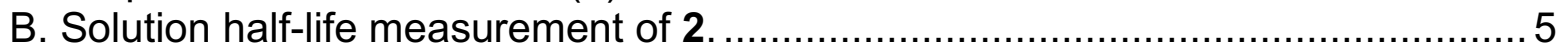

C. In situ generation of tBuLFeNMes('BuPy) .................................................... 5

D. Solution half-life measurement of tBuLFeNMes('BuPy) .................................. 6

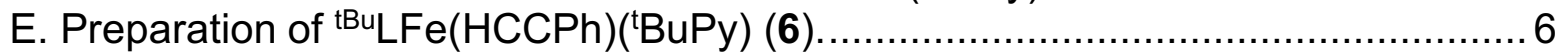

F. Determination of the equilibrium constant for the formation of $6 \ldots \ldots \ldots \ldots \ldots \ldots \ldots \ldots . . . . . . . . . . .6$

Figure S1. Binding curve for the formation of 6 from 0-400 mM ['BuPy] $]_{0 . \ldots \ldots \ldots . . . . . . . .7} 7$

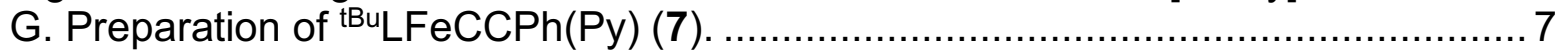

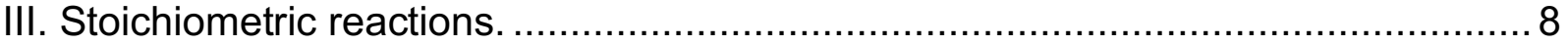

A. Reaction of tBuLFeNMes (2) with 1 equivalent of phenylacetylene ...................... 8

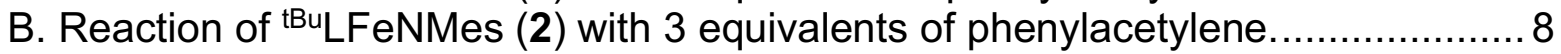

C. Reaction of tBuLFeNMes (2) with 3 equivalents of phenylacetylene and BuPy....9

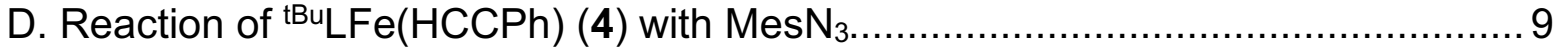

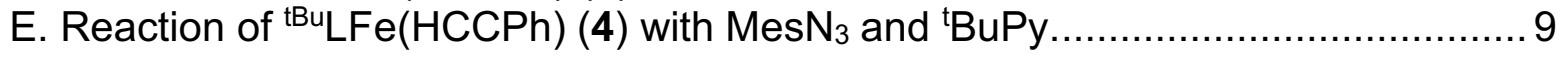

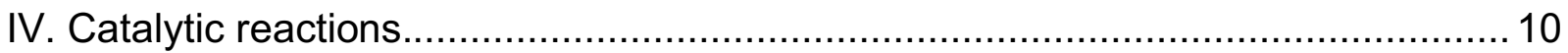

A. Attempted catalytic reaction with no additive .............................................. 10

B. Attempted catalytic reaction with no additive (simultaneous addition)............... 10

C. Catalytic reaction with 40 mol\% tBuPy.................................................. 10

D. General procedure for the catalytic reaction with $40 \mathrm{~mol} \%$ tBuPy to form $\mathbf{3 b}-\mathbf{3 e}$.

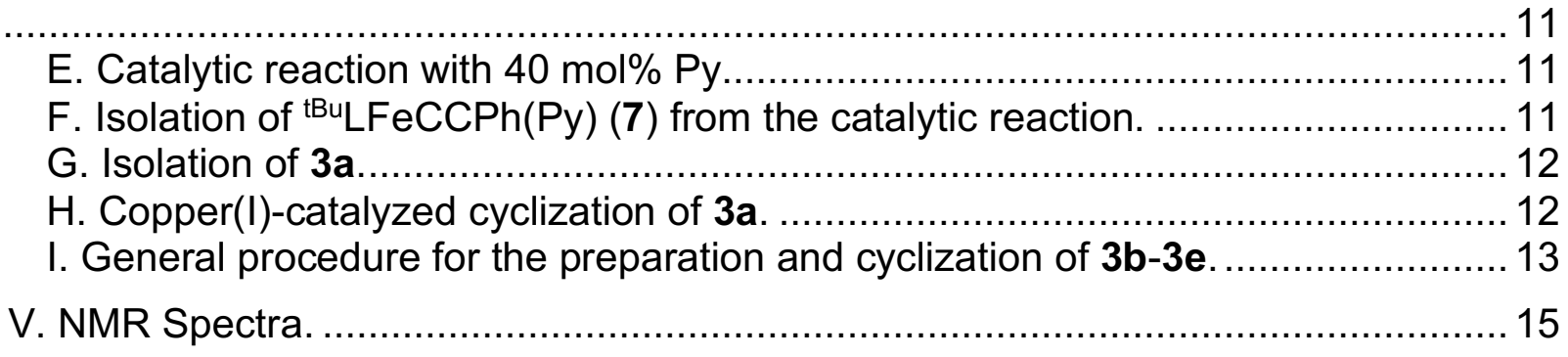




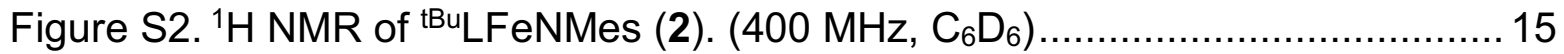

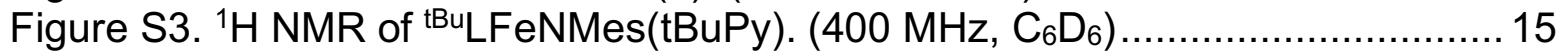

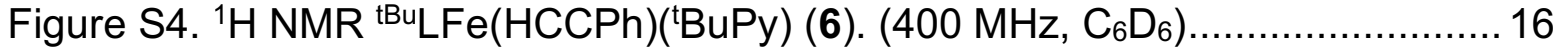

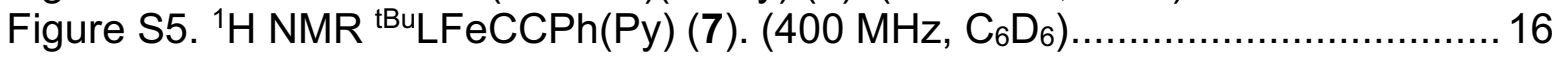

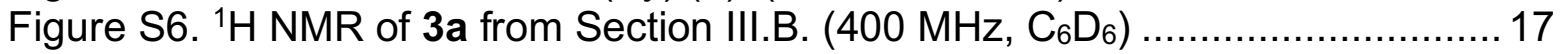

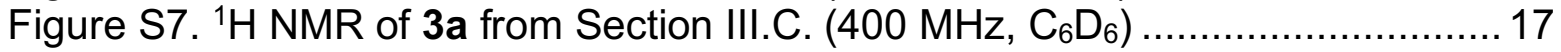

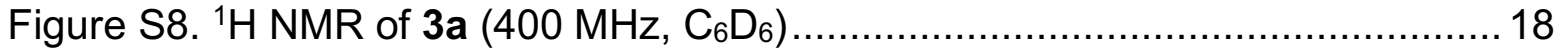

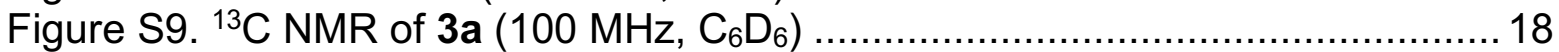

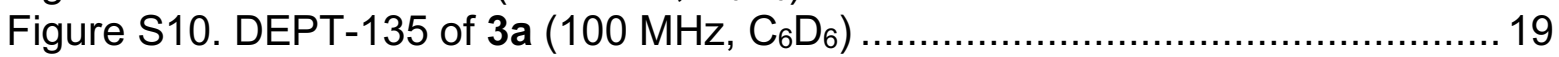

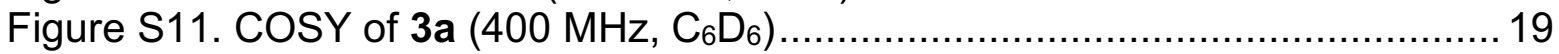

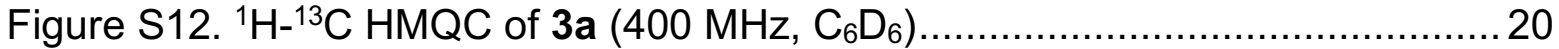

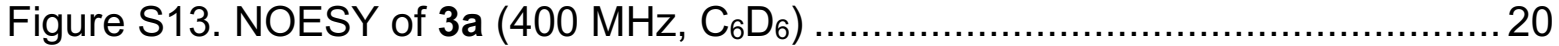

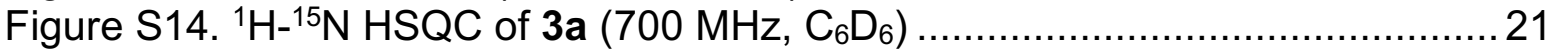

Figure S15. ${ }^{1} \mathrm{H}$ NMR of 1-mesityl-2,4-bis(4-methoxyphenyl)-1 $\mathrm{H}$-pyrrole $(400 \mathrm{MHz}$,

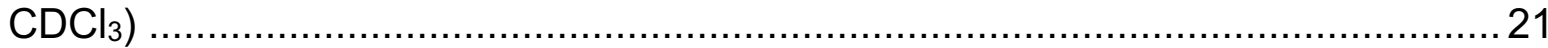

Figure S16. ${ }^{13} \mathrm{C}$ NMR of 1-mesityl-2,4-bis(4-methoxyphenyl)-1H-pyrrole $(100 \mathrm{MHz}$,

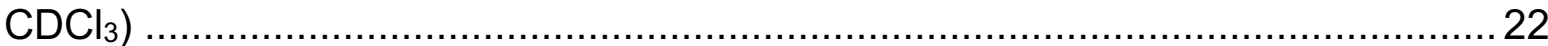

Figure S17. ${ }^{1} \mathrm{H}$ NMR of 1-mesityl-2,4-bis(4-tolyl)-1H-pyrrole $\left(400 \mathrm{MHz}, \mathrm{CDCl}_{3}\right) \ldots . .22$

Figure S18. ${ }^{13} \mathrm{C}$ NMR of 1-mesityl-2,4-bis(4-tolyl)-1 $\mathrm{H}$-pyrrole $\left(100 \mathrm{MHz}, \mathrm{CDCl}_{3}\right) \ldots 23$

Figure S19. ${ }^{1} \mathrm{H}$ NMR of 1-mesityl-2,4-bis(4-fluorophenyl)-1 $\mathrm{H}$-pyrrole $(400 \mathrm{MHz}$,

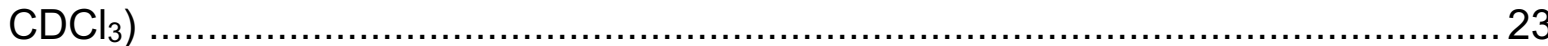

Figure S20. ${ }^{13} \mathrm{C}$ NMR of 1-mesityl-2,4-bis(4-fluorophenyl)-1 H-pyrrole $(100 \mathrm{MHz}$,

$\left.\mathrm{CDCl}_{3}\right)$

Figure S21. ${ }^{1} \mathrm{H}$ NMR of 1-mesityl-2,4-bis(4-trifluoromethylphenyl)-1H-pyrrole (400

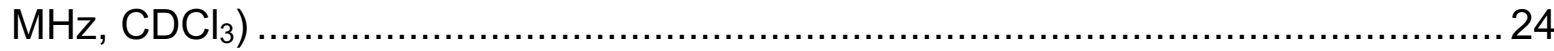

Figure S22. ${ }^{13} \mathrm{C}$ NMR of 1-mesityl-2,4-bis(4-trifluoromethylphenyl)-1H-pyrrole (100

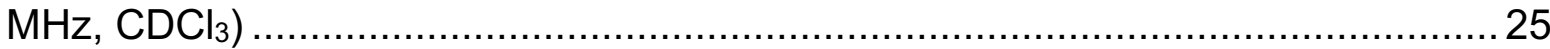

Figure S23. ${ }^{19} \mathrm{~F}$ NMR of 1-mesityl-2,4-bis(4-fluorophenyl)-1H-pyrrole $(376 \mathrm{MHz}$,

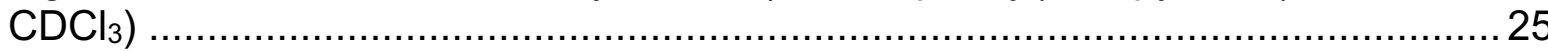

Figure S24. ${ }^{19} \mathrm{~F}$ NMR of 1-mesityl-2,4-bis(4-trifluoromethylphenyl)-1H-pyrrole (376

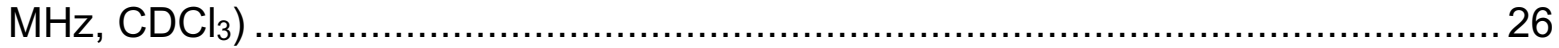

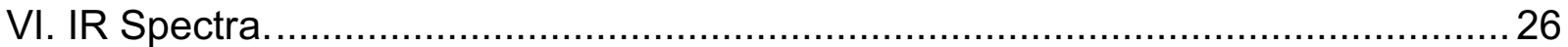

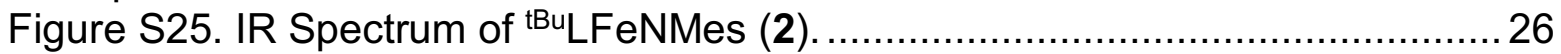

Figure S26. IR Spectrum of tBuLFe(HCCPh)('BuPy) (6) .................................. 27

Figure S27. IR Spectrum of tBuLFeCCPh(Py) (7) ........................................... 27

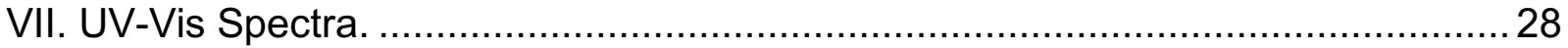

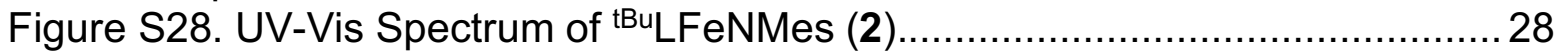

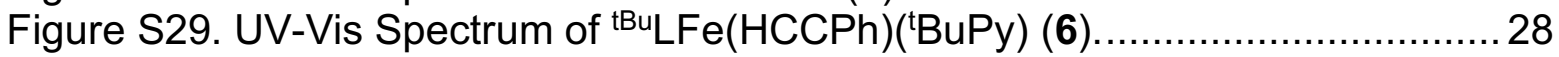

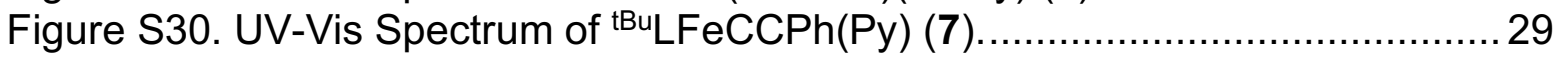

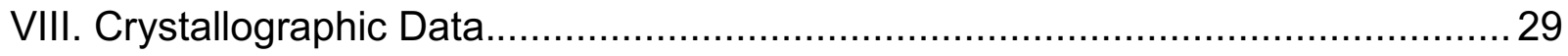

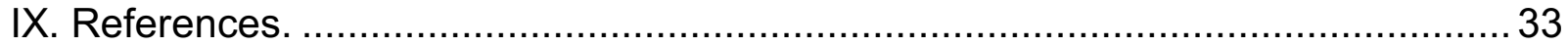




\section{Experimental Section}

\section{General Considerations.}

All air- and moisture-sensitive manipulations were carried out in an M. Braun inert atmosphere drybox containing an atmosphere of purified nitrogen. The drybox was equipped with a cold well for cooling in liquid nitrogen. Solvents for air- and moisturesensitive manipulations were passed through two columns of $3 \AA$ molecular sieves under argon and then stored over $4 \AA$ molecular sieves in the drybox. Diethyl ether and tetrahydrofuran were additionally distilled from a purple sodium/benzophenone ketyl mixture. $\mathrm{C}_{6} \mathrm{D}_{6}$ was dried over calcium hydride and stored in the drybox. Solvents were tested for moisture before use with a ketyl THF solution. ${ }^{\mathrm{BB} u} \mathrm{LFeCl},{ }^{1{ }^{\mathrm{BB}} \mathrm{LFeNNFe}} \mathrm{CHu}^{\mathrm{tBu}}(\mathbf{1}),{ }^{2}$ tBuLFe(HCCPh) (4), ${ }^{3}$ tBuLFeCCPh (5), ${ }^{4}$ mesityl azide, ${ }^{5}$ potassium graphite, ${ }^{6}$ and lithium phenylacetylide ${ }^{7}$ were prepared according to literature procedures. Caution! Organic azides have the potential to decompose violently in the presence of heat, light, pressure, or friction. They should be handled with caution using either plastic or glass implements. Contact with metal should be avoided. Preparation of mesityl azide was performed in a flask open to the atmosphere, in a fume hood, behind a blast shield while avoiding direct exposure to light. After purification, mesityl azide was dried over molecular sieves, brought into the drybox, and stored at $-35^{\circ} \mathrm{C}$ in the freezer. 4-tert-Butylpyridine, pyridine, phenylacetylene, and arylacetylene derivatives were purchased from commercial sources, dried over calcium hydride, and stored in the drybox. 1,3,5-Trimethoxybenzene was purchased from Oakwood Chemical, dried under vacuum, and recrystallized from dry THF in the drybox. Hydrogen sulfide was generated by addition of a 1:1 $\mathrm{v} / \mathrm{V} 98 \%$ sulfuric acid and water mixture to sodium sulfide (Millipore Sigma) under an argon atmosphere and captured in a balloon for use.

NMR spectra were recorded on a Bruker 400 UltraShield spectrometer operating at $400.13 \mathrm{MHz}$ at $25^{\circ} \mathrm{C}$ with the exception of the ${ }^{1} \mathrm{H}-{ }^{15} \mathrm{~N}$ HSQC experiment, which was recorded on a Bruker 700 Avance III spectrometer operating at $700.15 \mathrm{MHz}$ at $25^{\circ} \mathrm{C}$. All ${ }^{1} \mathrm{H}$ and ${ }^{13} \mathrm{C}$ NMR chemical shifts are reported in parts per million $(\mathrm{ppm})$ relative to the chemical shifts of residual protiated solvent. ${ }^{19} \mathrm{~F}$ NMR chemicals shifts are reported relative to fluorobenzene $(-113.15 \mathrm{ppm})$ as an internal standard. All signals of organometallic compounds are observed as broad singlets unless otherwise noted. Proton signal data is expressed using the following abbreviations: $s=$ singlet, $\mathrm{d}=$ doublet, $\mathrm{t}=$ triplet, $\mathrm{m}=$ multiplet, $\mathrm{J}=$ coupling constant.

Magnetic susceptibility data were collected either on a Johnson Matthey magnetic susceptibility balance (Gouy, $23{ }^{\circ} \mathrm{C}$ ) or on a Bruker 400 UltraShield spectrometer operating at $400.13 \mathrm{MHz}$ (Evans, $25^{\circ} \mathrm{C}$ ). IR spectra were recorded on a Shimadzu IRAffinity-1S Fourier Transform IR spectrophotometer. UV-Vis spectra were collected on an Agilent Cary 100 UV-Vis spectrophotometer. Elemental analyses were determined by Midwest Microlab, Indianapolis, IN.

Crystals of compounds 2, 6, and $\mathbf{7}$ of appropriate dimension were obtained by slow evaporation from a saturated pentane solution at $-35^{\circ} \mathrm{C}$. The crystals were coated with 
polyisobutylene oil in a drybox and mounted on MiTeGen cryoloops in random orientations for data collection. Preliminary examination and data collection were performed using a Bruker Venture Duo Photon-II single crystal X-ray diffractometer equipped with an Oxford Cryostream LT device. Data sets were collected using an Incoatec l $\mu \mathrm{S}$ micro-focus source ( $\mathrm{Cu}$ or $\mathrm{Mo}$ ) with multi-layer mirror optics. Preliminary unit cell constants were determined from a set of 180 degree fast $\varphi$ scan frames (typically, 1 second exposure, $1^{\circ}$ scan). Intensity data collections consist of combinations of $\omega$ and $\varphi$ scan frames with typical scan width of $0.5^{\circ}$ and counting time of 1 to 10 seconds/frame at a crystal to detector distance of $3.7 \mathrm{~cm}$. The collected frames were integrated using an orientation matrix determined from the narrow frame scans. Apex II and SAINT software packages ${ }^{8}$ were used for data collection and data integration. Analysis of the integrated data did not show any decay. Final cell constants were determined by global refinement of reflections harvested from the complete data set. Collected data were corrected for systematic errors using $\mathrm{SADABS}^{8}$ based on the Laue symmetry using equivalent reflections. Crystal data and intensity data collection parameters are listed in Table S2.

Structure solution and refinement were carried out using the SHELXTL-PLUS software package. ${ }^{9}$ The structures for $\mathbf{2}$ and $\mathbf{7}$ were solved by direct methods and refined successfully in the monoclinic space group, P2 $1 / \mathrm{c}$. The structure of 6 was solved and refined successfully in the monoclinic space group, $\mathrm{P}-1$. Full matrix least-squares refinements were carried out by minimizing $\Sigma w\left(F_{o}^{2}-F_{c}^{2}\right)^{2}$. The non-hydrogen atoms were refined anisotropically to convergence. All hydrogen atoms were treated using appropriate riding model (AFIX m3). The crystal lattice of compound 7 contains pentane as solvent of crystallization. The solvent molecule sits on an inversion center. The full molecule was refined with PART-1 and displacement parameter constraints. The final residual values and structure refinement parameters are listed in Table S2.

Twin refinement for 6 was carried out using HKLF 5 data (two component twin). The non-hydrogen atoms were refined anisotropically to convergence. The acetylene hydrogen was located and refined. All other hydrogen atoms were treated using the appropriate riding model (AFIX m3).

\section{Disorder modeling:}

The Fe in $\mathbf{6}$ is disordered over two positions and partial occupancies were refined to $94: 6 \%$. This disorder was modeled with partial occupancy atoms $(57: 43 \%)$ in two positions. The ${ }^{\mathrm{t}} \mathrm{BuPy}$ ring is disordered over two orientations and the disorder was modeled using partial occupancy atoms which refined to $68: 32 \%$. All disordered motifs were refined with geometrical restraints and displacement parameter constraints.

Tables of calculated and observed structure factors are available in electronic format. Picture representations of molecular structures were rendered using Olex2 software. ${ }^{10}$ 


\section{Preparation of Iron Complexes.}

A. Preparation of tBuLFeNMes (2).

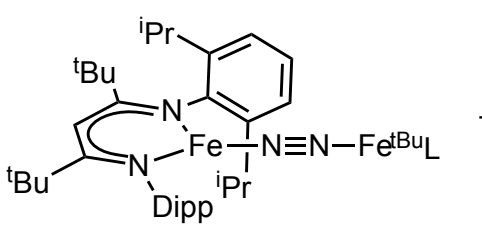<smiles>Cc1cc(C)c(N)c(C)c1</smiles>

2 equiv

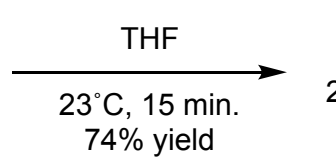

西

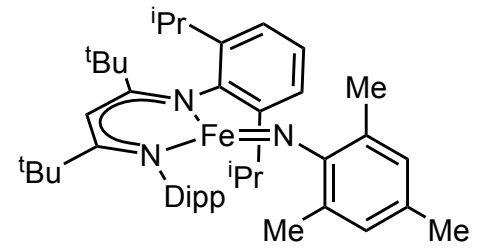

2

A $20 \mathrm{~mL}$ scintillation vial was charged with a stir bar, $0.212 \mathrm{~g}$ (185 $\mu \mathrm{mol}, 1.0$ equiv) of ${ }^{\text {tBuLFeNNFe }}{ }^{\mathrm{tBu}} \mathrm{L}$, and $15 \mathrm{~mL}$ of THF to give a dark red solution. A solution of $0.061 \mathrm{~g}$ (377 $\mu \mathrm{mol}, 2.0$ equiv) of $\mathrm{MesN}_{3}$ in $2 \mathrm{~mL}$ THF was prepared separately. The Mes $\mathrm{N}_{3}$ solution was then added drop-wise to the stirring solution of tBuLFeNNFe ${ }^{\mathrm{tBu}} \mathrm{L}$. A color change to orange-red was observed along with vigorous effervescence. The reaction mixture was stirred for 15 minutes at room temperature, and then the volatiles were removed under vacuum. The resulting solids were dissolved in pentane, filtered through Celite, and concentrated until a solid began to form. The concentrated solution was stored overnight at $-35{ }^{\circ} \mathrm{C}$ to give $0.179 \mathrm{~g}$ ( $74 \%$ yield) of tBuLFeNMes as very dark crystals in two crops. Crystals suitable for $\mathrm{X}$-ray diffraction were obtained from a saturated pentane solution at $-35^{\circ} \mathrm{C} .{ }^{1} \mathrm{H}$ NMR $\left(400 \mathrm{MHz}, \mathrm{C}_{6} \mathrm{D}_{6}, 25^{\circ} \mathrm{C}\right): \delta 56(6 \mathrm{H}$, Mes o-CH $), 53\left(1 \mathrm{H},{ }^{\mathrm{tBu}} \mathrm{L} \alpha-\mathrm{CH}\right), 45$ $(2 \mathrm{H}$, Mes $m-\mathrm{CH}), 37\left(3 \mathrm{H}\right.$, Mes $\left.p-\mathrm{CH}_{3}\right), 22\left(18 \mathrm{H}\right.$, $\left.{ }^{\text {tBu }} \mathrm{L} \mathrm{C}\left(\mathrm{CH}_{3}\right)_{3}\right),-9.1\left(4 \mathrm{H},{ }^{\text {tBuL }} m-\mathrm{CH}\right),-14$

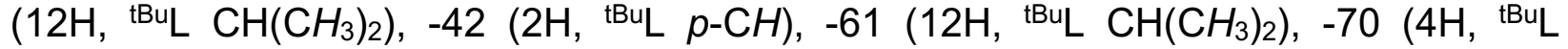
$\left.\mathrm{CH}\left(\mathrm{CH}_{3}\right)_{2}\right)$. IR (KBr): 3307, 3055, 2959, 2868, 1925, 1859, 1730, 1593, 1537, 1487, 1433. UV/Vis (pentane): $336\left(26 \mathrm{mM}^{-1} \mathrm{~cm}^{-1}\right), 435$ (sh, $\left.\sim 5.9 \mathrm{mM}^{-1} \mathrm{~cm}^{-1}\right), 517\left(\mathrm{sh}, \sim 3.5 \mathrm{mM}^{-1} \mathrm{~cm}^{-1}\right)$. Magnetic moment (Gouy balance, $23^{\circ} \mathrm{C}$ ) $\mu_{\text {eff }}=4.3(8) \mu_{\mathrm{B}} ;\left(\right.$ Evans, $\left.25^{\circ} \mathrm{C}\right)$, $\mu_{\text {eff }}=4.4(5) \mu_{\mathrm{B}}$. Anal. Calcd for $\mathrm{C}_{44} \mathrm{H}_{64} \mathrm{~N}_{3} \mathrm{Fe}$ : C, 76.50; $\mathrm{H}, 9.34 ; \mathrm{N}, 6.08$. Found: $\mathrm{C}, 76.01 ; \mathrm{H}, 8.94 ; \mathrm{N}, 5.94$.

\section{B. Solution half-life measurement of 2.}

A J-Young NMR tube was charged with $26.0 \mathrm{mg}(37.6 \mu \mathrm{mol})$ of tBuLFeNMes and $376 \mu \mathrm{L}$ of $\mathrm{C}_{6} \mathrm{D}_{6}$. The decomposition was followed by ${ }^{1} \mathrm{H}$ NMR spectroscopy. A half-life of $\sim 4$ days was determined based on signal integration compared to residual $\mathrm{C}_{6} \mathrm{D}_{5} \mathrm{H}$.

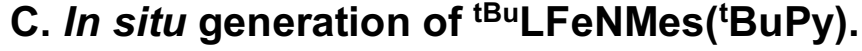

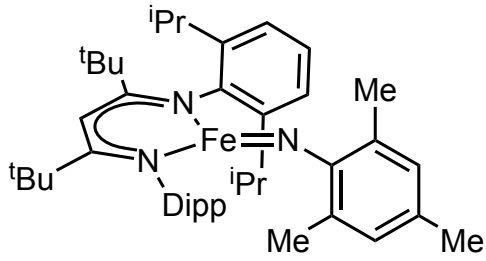

2<smiles>Brc1ccncc1</smiles>

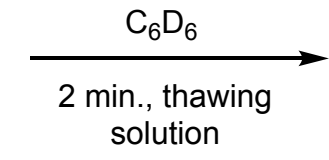

A J-Young NMR tube was charged with $15.5 \mathrm{mg}$ (22 $\mu \mathrm{mol}, 1.0$ equiv) of tBuLFeNMes (2) and $225 \mu \mathrm{L}$ of $\mathrm{C}_{6} \mathrm{D}_{6}$. The solution was frozen in a liquid nitrogen-cooled cold well. $3.0 \mathrm{mg}$ (22 $\mu \mathrm{mol}, 1.0$ equiv) of 4-tert-butylpyridine was added. The ${ }^{1} \mathrm{H}$ NMR spectrum collected immediately after thawing showed complete consumption of tBuLFeNMes. ${ }^{1} \mathrm{H}$ NMR (400 $\left.\mathrm{MHz}, \mathrm{C}_{6} \mathrm{D}_{6}, 25^{\circ} \mathrm{C}\right): \delta 18\left(18 \mathrm{H},{ }^{\mathrm{tBu}} \mathrm{L} \mathrm{C}\left(\mathrm{CH}_{3}\right)_{3}\right), 0.92\left(9 \mathrm{H}\right.$, $\left.{ }^{\mathrm{B}} \mathrm{BuPy} \mathrm{C}\left(\mathrm{CH}_{3}\right)_{3}\right),-1.7(4 \mathrm{H}$, tBuL $m-$ 
$\mathrm{CH}),-9.1\left(12 \mathrm{H},{ }^{\mathrm{tBu}} \mathrm{L} \mathrm{CH}\left(\mathrm{CH}_{3}\right)_{2}\right),-35\left(2 \mathrm{H},{ }^{\mathrm{tBu}} \mathrm{L} \mathrm{p}-\mathrm{CH}\right),-43\left(12 \mathrm{H},{ }^{\mathrm{tBu}} \mathrm{L} \mathrm{CH}\left(\mathrm{CH}_{3}\right)_{2}\right),-48(4 \mathrm{H}$, tBuL $\left.\mathrm{CH}\left(\mathrm{CH}_{3}\right)_{2}\right)$.

\section{Solution half-life measurement of tBuLFeNMes('BuPy).}

The sample from the preparation of tBuLFeNMes('BuPy) was monitored over the course of 3 hours by ${ }^{1} \mathrm{H}$ NMR spectroscopy. A half-life of $\sim 1.5$ hours was determined based on signal integration compared to residual $\mathrm{C}_{6} \mathrm{D}_{5} \mathrm{H}$.

\section{E. Preparation of tBuLFe(HCCPh)('BuPy) (6).}

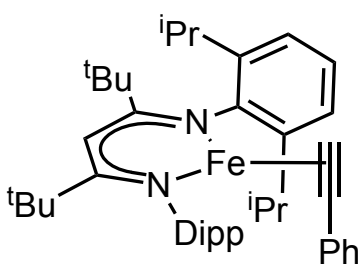

4

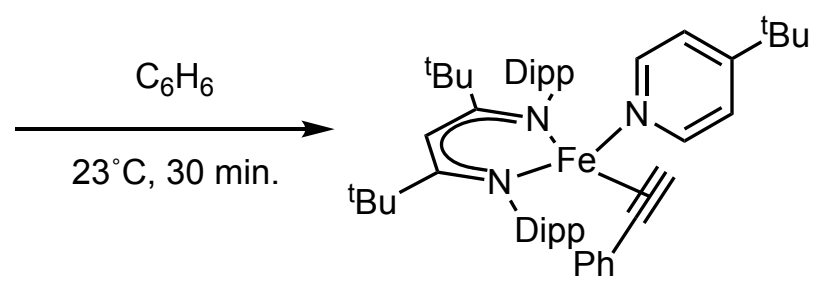

6

In a $20-\mathrm{mL}$ scintillation vial equipped with a stir bar, $74.4 \mathrm{mg}(113 \mu \mathrm{mol}, 1.0$ equiv $)$ of tBu $\mathrm{LFe}(\mathrm{HCCPh})(4)$ was dissolved in $2 \mathrm{~mL}$ of benzene $(56 \mathrm{mM})$ to give a dark red solution.

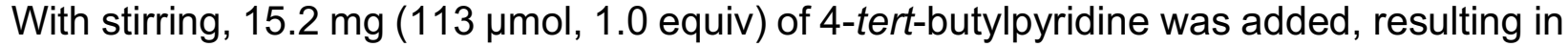
a color change to purple. The reaction mixture was stirred for 30 minutes at room temperature, and then volatiles were removed under vacuum. The resulting solid was then dissolved in a minimum amount of pentane $(\sim 2 \mathrm{~mL})$, filtered through Celite, and concentrated in vacuo until solids began to form. The solution was stored at $-35^{\circ} \mathrm{C}$ overnight to give dark purple crystals of ${ }^{\mathrm{tBu}} \mathrm{LFe}(\mathrm{HCCPh})\left({ }^{\mathrm{t} B u P y}\right)(66 \mathrm{mg}, 74 \%$ yield) in a single crop. ${ }^{1} \mathrm{H}$ NMR $\left(400 \mathrm{MHz}, \mathrm{C}_{6} \mathrm{D}_{6}, 25^{\circ} \mathrm{C}\right): \delta 20\left(18 \mathrm{H},{ }^{\mathrm{tBu}} \mathrm{L} \mathrm{C}\left(\mathrm{CH}_{3}\right)_{3}\right), 13\left(2 \mathrm{H}, o_{-}\right.$or $\mathrm{m}$ $\mathrm{Ph}$ or $o$ - or $m$ - $\left.{ }^{\mathrm{t} B u P y}\right), 10\left(2 \mathrm{H} o-\right.$ or $m$-Ph or $o$ - or $m$ - $\left.{ }^{\mathrm{B} u \mathrm{Bu}}\right), 3.4(1 \mathrm{H}), 2.4(2 \mathrm{H} \mathrm{o-} \mathrm{or} m-\mathrm{Ph}$ or o- or $m$-'BuPy), 0.33 (9H tBuPy, $\left.\mathrm{C}\left(\mathrm{CH}_{3}\right)_{3}\right),-3.6\left(4 \mathrm{H},{ }^{\mathrm{tBu}} \mathrm{L} m-\mathrm{CH}\right),-4.2(1 \mathrm{H}, p-\mathrm{Ph}),-11$ $\left(12 \mathrm{H}\right.$, tBuL C $\left.\left(\mathrm{CH}_{3}\right)_{3}\right),-27\left(2 \mathrm{H}\right.$, $\left.{ }^{\mathrm{tBu}} \mathrm{L} \mathrm{p}-\mathrm{CH}\right),-52\left(12 \mathrm{H}\right.$, $\left.{ }^{\mathrm{tBu}} \mathrm{L} \mathrm{CH}\left(\mathrm{CH}_{3}\right)_{2}\right)$. IR $(\mathrm{KBr}): 3057,3021$, 2963, 2926, 2905, 2866, 1739, 1608, 1589, 1530, 1499, 1483, 1466, 1433. UV/Vis (pentane): $339\left(16.9 \mathrm{mM}^{-1} \mathrm{~cm}^{-1}\right), 409\left(8.5 \mathrm{mM}^{-1} \mathrm{~cm}^{-1}\right), 557\left(\sim 0.8 \mathrm{mM}^{-1} \mathrm{~cm}^{-1}\right), 769\left(\sim 0.4 \mathrm{mM}^{-}\right.$ ${ }^{1} \mathrm{Cm}^{-1}$ ). Magnetic moment (Gouy balance, $\left.23^{\circ} \mathrm{C}\right) \mu_{\text {eff }}=3.9(8) \mu_{\mathrm{B}}\left(\right.$ Evans, $\left.25^{\circ} \mathrm{C}\right), \mu_{\text {eff }}=4.4(9)$

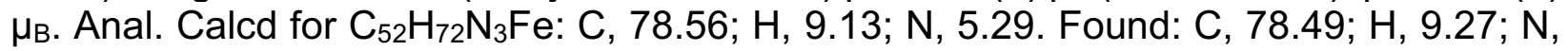
5.26 .

F. Determination of the equilibrium constant for the formation of 6.

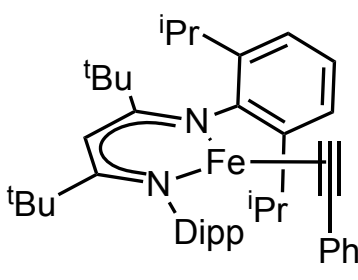

4<smiles>CC(C)(C)c1ccncc1</smiles>

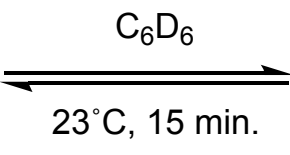

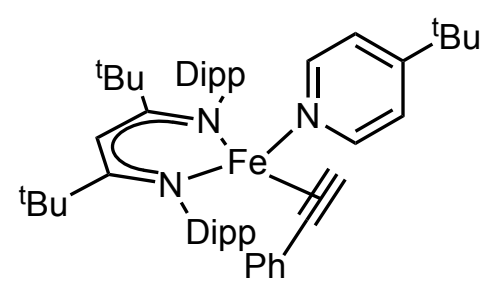

6

To a J Young NMR tube containing $400 \mu \mathrm{L}$ of a $20 \mathrm{mM}$ solution of 4 , the appropriate amount of 4-tert-butylpyridine was added according to the table below. The NMR tube was capped and shaken to mix. ${ }^{1} \mathrm{H}$ NMR was taken after 15 minutes, and the change in 
ppm was recorded for the $m$-Ar peak (-16 ppm for ['BuPy $\left.]_{0}=0 \mathrm{mM}\right)$. Each sample was prepared in triplicate. A plot of $\Delta \delta$ vs. ['BuPy] was created, and the data were fitted to a weak-binding equation ${ }^{11}$ using GraphPad Prism version 9.1.2 for Mac OS X, GraphPad Software, San Diego, California USA www.graphpad.com.

Table S1. Amounts of tBuPy added.

\begin{tabular}{|c|c|c|}
\hline$[\mathrm{tBuPy}]_{0}$ & $\mu \mathrm{mol}$ & Amount added $(\mu \mathrm{L})$ \\
\hline 0 & 0 & 0 \\
\hline 20 & 8 & 1.17 \\
\hline 40 & 16 & 2.34 \\
\hline 100 & 40 & 5.86 \\
\hline 200 & 80 & 11.7 \\
\hline 300 & 120 & 17.6 \\
\hline 400 & 160 & 23.4 \\
\hline
\end{tabular}

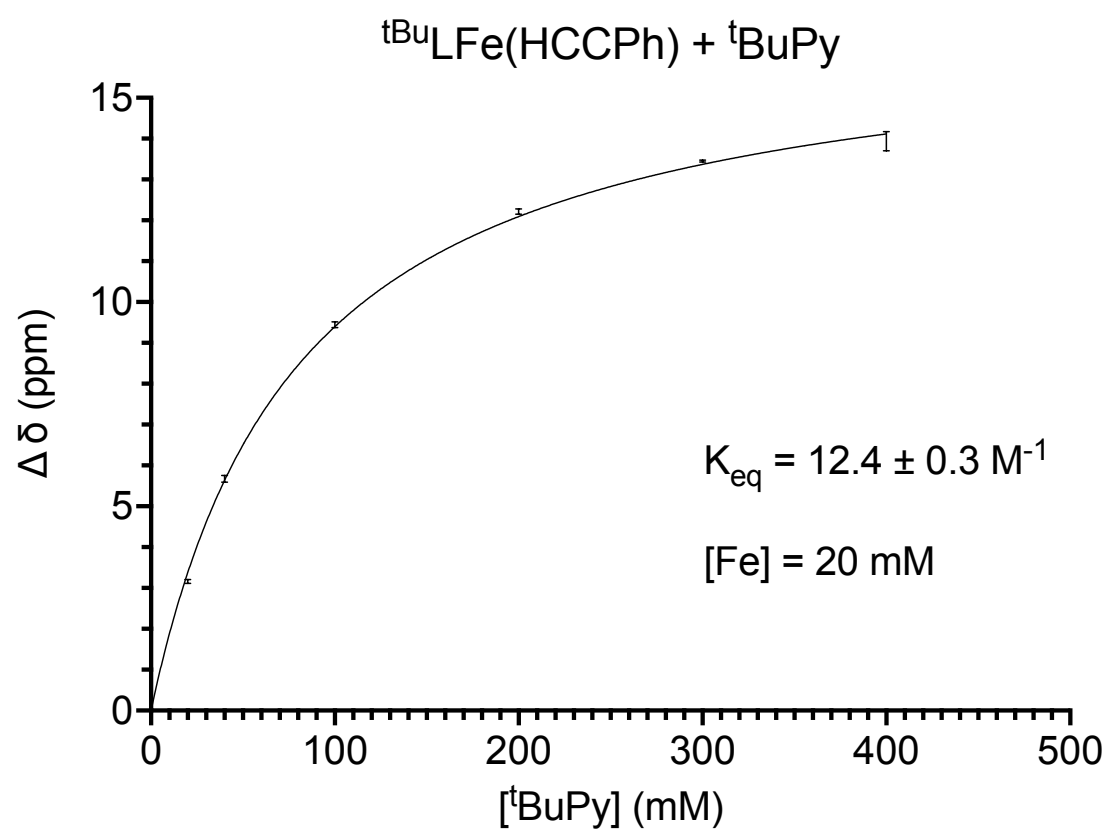

Figure S1. Binding curve for the formation of 6 from 0-400 mM ['BuPy]o.

G. Preparation of tBuLFeCCPh(Py) (7).

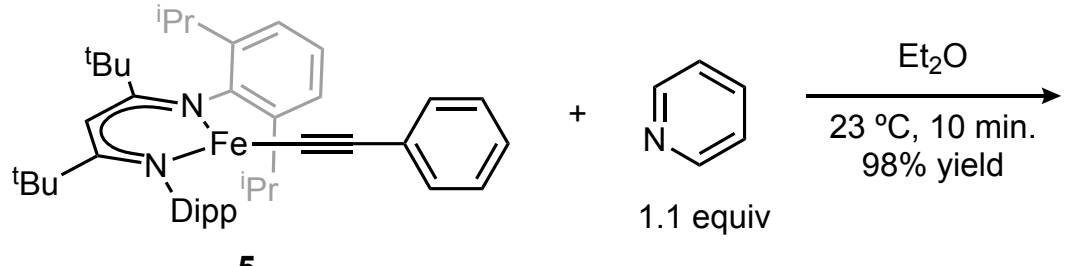<smiles></smiles>

In a $20 \mathrm{~mL}$ scintillation vial, $104 \mathrm{mg}(158 \mu \mathrm{mol}, 1.0$ equiv $)$ of tBuLFeCCPh was dissolved in $2 \mathrm{~mL}$ of diethyl ether to give an orange solution. $14 \mu \mathrm{L}$ (173 $\mu \mathrm{mol}, 1.1$ equiv) of pyridine 
was added while stirring, resulting in an immediate color change to yellow-orange and some precipitation of solids. After stirring for 20 minutes at room temperature, the volatiles were removed under vacuum. The solids were washed with pentane $(2 \times 5 \mathrm{~mL})$ to give $79 \mathrm{mg}$ of an orange solid. After concentrating the washes to $\sim 2 \mathrm{~mL}$, an additional $35 \mathrm{mg}$ were collected, giving a combined yield of $114 \mathrm{mg}\left(98 \%\right.$ yield) of ${ }^{\mathrm{BBu}} \mathrm{LFeCCPh}(\mathrm{py}) .{ }^{1} \mathrm{H}$ $\operatorname{NMR}\left(400 \mathrm{MHz}, \mathrm{C}_{6} \mathrm{D}_{6}, 25^{\circ} \mathrm{C}\right): \delta 32(2 \mathrm{H}), 29(1 \mathrm{H}), 23(4 \mathrm{H}), 9.2(18 \mathrm{H}), 0.18(8 \mathrm{H}),-7.2(7 \mathrm{H})$, $-27(2 \mathrm{H}),-30(1 \mathrm{H}),-54(2 \mathrm{H})$. IR (KBr): 3056, 3022, 2965, 2907, 2868, 2076, 1935, 1867 , 1794, 1665, 1626, 1599, 1528, 1484, 1445, 1433. UV/Vis $\left(\mathrm{Et}_{2} \mathrm{O}\right): 337\left(19.5 \mathrm{mM}^{-1} \mathrm{~cm}^{-1}\right)$, $382\left(8.3 \mathrm{mM}^{-1} \mathrm{~cm}^{-1}\right), 443\left(\mathrm{sh}, 2.2 \mathrm{mM}^{-1} \mathrm{~cm}^{-1}\right), 508\left(\sim 0.9 \mathrm{mM}^{-1} \mathrm{~cm}^{-1}\right), 540\left(\mathrm{sh}, \sim 0.7 \mathrm{mM}^{-1} \mathrm{~cm}^{-}\right.$ $\left.{ }^{1}\right)$. Magnetic moment (Gouy balance, $\left.23^{\circ} \mathrm{C}\right) \mu_{\text {eff }}=5.1(2) \mu_{\mathrm{B}} ;\left(\right.$ Evans, $\left.25^{\circ} \mathrm{C}\right): \mu_{\text {eff }}=5.5(2) \mu_{\mathrm{B}}$. Anal. Calcd for $\mathrm{C}_{48} \mathrm{H}_{63} \mathrm{~N}_{3} \mathrm{Fe}$ : C, 78.13; H, 8.61; N, 5.69. Found: C, 77.57; H, 9.06; N, 5.60.

\section{Stoichiometric reactions.}

\section{A. Reaction of tBuLFeNMes (2) with 1 equivalent of phenylacetylene.}

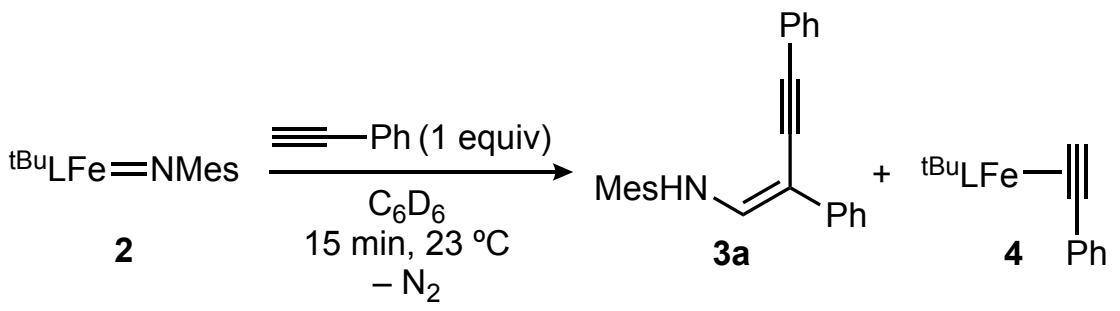

A J-Young NMR tube was charged with $20.0 \mathrm{mg}(29 \mu \mathrm{mol}, 1.0$ equiv) of 2 and $500 \mu \mathrm{L}$ of $\mathrm{C}_{6} \mathrm{D}_{6}$ to give a red-orange solution. To the solution was added $3.3 \mu \mathrm{L}(29 \mu \mathrm{mol}, 1.0$ equiv) of phenylacetylene. A very slight color change to orange was observed. Analysis by ${ }^{1} \mathrm{H}$ NMR after 15 minutes at room temperature showed partial conversion of 2 along with the formation of $\mathbf{3 a}$ and 4 .

\section{B. Reaction of tBuLFeNMes (2) with 3 equivalents of phenylacetylene.}

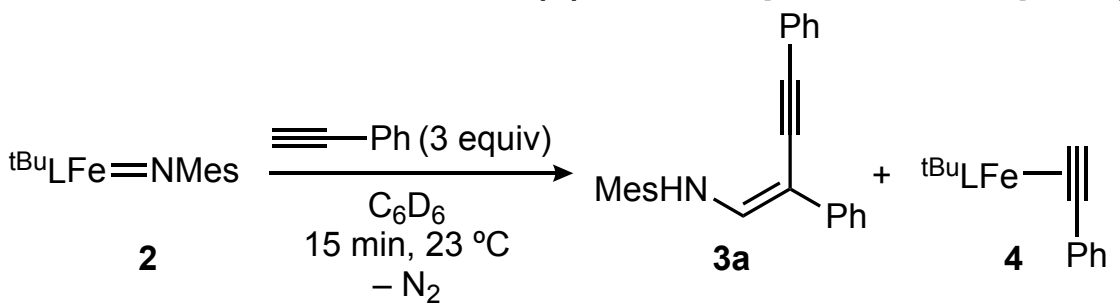

A J-Young NMR tube was charged with $16.8 \mathrm{mg}(24.3 \mu \mathrm{mol}, 1.0$ equiv) of 2 and $325 \mu \mathrm{L}$ of $\mathrm{C}_{6} \mathrm{D}_{6}$ to give a red-orange solution. To the solution was added $8.1 \mu \mathrm{L}(73.0 \mu \mathrm{mol}, 3.0$ equiv) of phenylacetylene. A very slight color change to orange was observed. Addition of $1.4 \mathrm{mg}$ of 1,3,5-trimethoxybenzene $(8.3 \mu \mathrm{mol}, 0.33$ equiv) and subsequent analysis by ${ }^{1} \mathrm{H}$ NMR spectroscopy after 15 minutes at room temperature showed complete conversion of 2 along with an $85 \%$ yield of $3 a$, and the presence of 4 . 


\section{Reaction of ${ }^{\mathrm{tBu}} \mathrm{LFeNMes}(2)$ with 3 equivalents of phenylacetylene and ${ }^{\mathrm{B}} \mathrm{BuPy}$.}

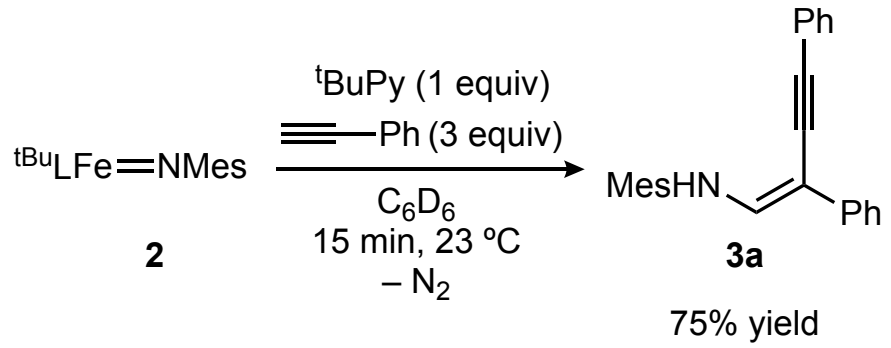

A J-Young NMR tube was charged with $15.0 \mathrm{mg}(21.7 \mu \mathrm{mol}, 1.0$ equiv) of 2 and $434 \mu \mathrm{L}$ of $\mathrm{C}_{6} \mathrm{D}_{6}$ to give a red-orange solution. In a separate vial, $2.9 \mathrm{mg}(21.7 \mu \mathrm{mol}, 1.0$ equiv) of 4-tert-butylpyridine and $6.7 \mathrm{mg}\left(21.7 \mu \mathrm{mol}, 1.0\right.$ equiv) of $\mathrm{Mes}_{3}$ were combined. This mixture was added to the solution of 2 and the NMR tube was capped and shaken. After 15 minutes, $1.2 \mathrm{mg}$ (7.2 $\mathrm{mmol}, 0.33$ equiv) of 1,3,5-trimethoxybenzene was added as an internal standard. ${ }^{1} \mathrm{H}$ NMR spectroscopy at room temperature showed complete conversion of $\mathbf{2}$ along with a $75 \%$ yield of $3 \mathbf{a}$.

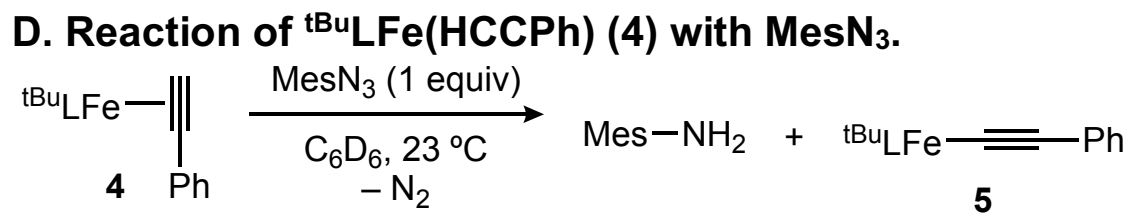

A J-Young NMR tube was charged with $17 \mathrm{mg} \mathrm{(26 \mu mol,} 1.0$ equiv) of tBuLFe(HCCPh) and $300 \mu \mathrm{L}$ of $\mathrm{C}_{6} \mathrm{D}_{6}$. To this mixture, $4.2 \mathrm{mg}\left(26 \mu \mathrm{mol}, 1.0\right.$ equiv) of $\mathrm{Mes}_{3}$ dissolved in $200 \mu \mathrm{L}$ of $\mathrm{C}_{6} \mathrm{D}_{6}$ were added, resulting in a color change from orange-red to blue. Analysis by ${ }^{1} \mathrm{H}$ NMR spectroscopy after 30 minutes showed formation of $\mathbf{5}$ as the major organometallic product. This mixture was transferred to a $10 \mathrm{~mL}$ round bottom flask in the drybox, which was sealed with a septum. The flask was sealed with a septum and treated with $\mathrm{H}_{2} \mathrm{~S}$, whereupon dark solids formed. The mixture was filtered through Celite and the volatiles were removed from the filtrate under vacuum. Analysis by ${ }^{1} \mathrm{H}$ NMR spectroscopy in $\mathrm{C}_{6} \mathrm{D}_{6}$ showed a $\sim 1: 1$ mixture of unreacted $\mathrm{Mes}_{3}$ and $\mathrm{MesNH}_{2}$.

\section{E. Reaction of ${ }^{\text {tBu}} \mathrm{LFe}(\mathrm{HCCPh})(4)$ with $\mathrm{MesN}_{3}$ and ${ }^{\mathrm{t}} \mathrm{BuPy}$.}

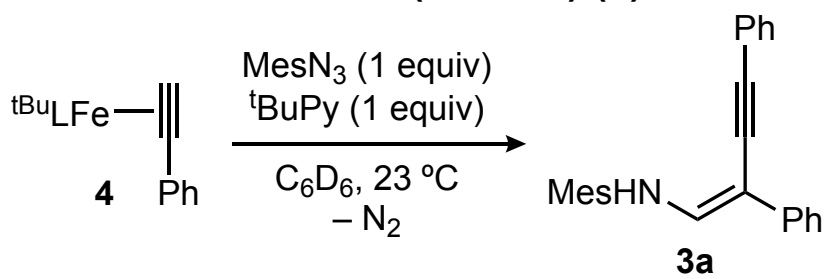

A $20 \mathrm{~mL}$ scintillation vial was charged with $10.1 \mathrm{mg}(15 \mu \mathrm{mol}, 1.0$ equiv) of tBuLFe(HCCPh) and $150 \mu \mathrm{L}$ of $\mathrm{C}_{6} \mathrm{D}_{6}$. A solution of $2.1 \mathrm{mg}(15 \mu \mathrm{mol}, 1.0$ equiv) of tBuPy, $2.5 \mathrm{mg}(15 \mu \mathrm{mol}$, 1.0 equiv) of $\mathrm{Mes}_{3}$, and $150 \mu \mathrm{L}$ of $\mathrm{C}_{6} \mathrm{D}_{6}$ was added. The mixture was transferred to a JYoung NMR tube. The ${ }^{1} \mathrm{H}$ NMR spectrum showed complete conversion of $\mathrm{MesN}_{3}$ to $3 a$ as well as the absence of $\mathrm{MesNH}_{2}$. 


\section{Catalytic reactions.}

\section{A. Attempted catalytic reaction with no additive.}

$$
\begin{aligned}
& \text { MesN }_{3}+\underset{2.1 \text { equiv }}{=} \frac{10 \mathrm{~mol} \%{ }^{\mathrm{tBu} L F e N N F e^{\mathrm{tBu} L}}}{\mathrm{C}_{6} \mathrm{D}_{6}, 23^{\circ} \mathrm{C}, 30 \mathrm{~min}}+\mathrm{MesNH}_{2} \\
& 20 \% \text { yield } \quad 10 \% \text { yield }
\end{aligned}
$$

To a $20 \mathrm{~mL}$ scintillation vial with a stir bar was added $20 \mathrm{mg}(18 \mu \mathrm{mol}, 0.1$ equiv) of tBuLFeNNFe ${ }^{\mathrm{tBu}} \mathrm{L}, 10 \mathrm{mg}$ (58 $\mu \mathrm{mol}, 0.33$ equiv) of 1,3,5-trimethoxybenzene as an internal standard, and $1.7 \mathrm{~mL} \mathrm{C}{ }_{6} \mathrm{D}_{6} .28 \mathrm{mg}\left(175 \mu \mathrm{mol}, 1.0\right.$ equiv) of $\mathrm{Mes}_{3}$ was added to the stirring solution. Effervescence was observed, along with a color change from red-purple

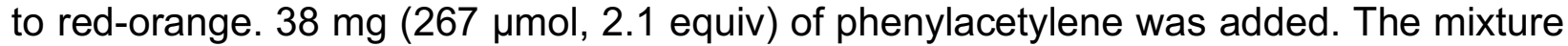
was allowed to stir for 30 minutes at room temperature, then was treated with $\mathrm{H}_{2} \mathrm{~S}$ (see section IV.D. below) and filtered through Celite. Analysis by ${ }^{1} \mathrm{H}$ NMR spectroscopy indicated the formation of $3 \mathbf{a}$ in $20 \%$ yield, as well as a $10 \%$ yield of $\mathrm{MesNH}_{2}$.

\section{B. Attempted catalytic reaction with no additive (simultaneous addition).}

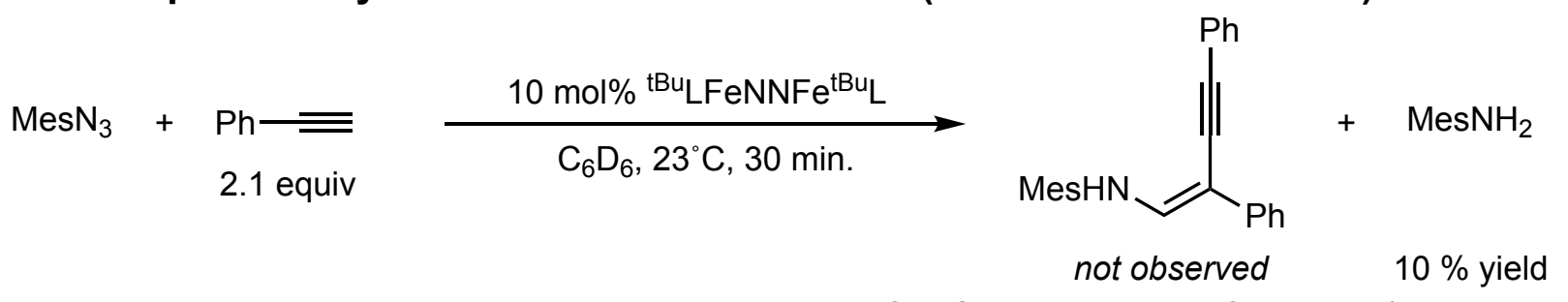

To a $20 \mathrm{~mL}$ scintillation vial was added $500 \mu \mathrm{L}$ of a $\mathrm{C}_{6} \mathrm{D}_{6}$ solution of Mes $\mathrm{N}_{3}(100 \mu \mathrm{mol}$, 1.0 equiv), phenylacetylene ( $210 \mu \mathrm{mol}, 2.1$ equiv), and 1,3,5-trimethoxybenzene (33 $\mu$ mol, 0.33 equiv). $500 \mu \mathrm{L}$ of a $\mathrm{C}_{6} \mathrm{D}_{6}$ solution of tBuLFeNNFe ${ }^{\mathrm{tBu}} \mathrm{L}$ ( $10 \mu \mathrm{mol}, 0.1$ equiv) was added. The mixture was allowed to stir for 30 minutes at room temperature, then was treated with $\mathrm{H}_{2} \mathrm{~S}$ and filtered through Celite. Analysis by ${ }^{1} \mathrm{H}$ NMR spectroscopy indicated no formation of $3 a$ and a $10 \%$ yield of $\mathrm{MesNH}_{2}$.

\section{Catalytic reaction with $40 \mathrm{~mol} \%{ }^{\mathrm{t}} \mathrm{BuPy}$.}

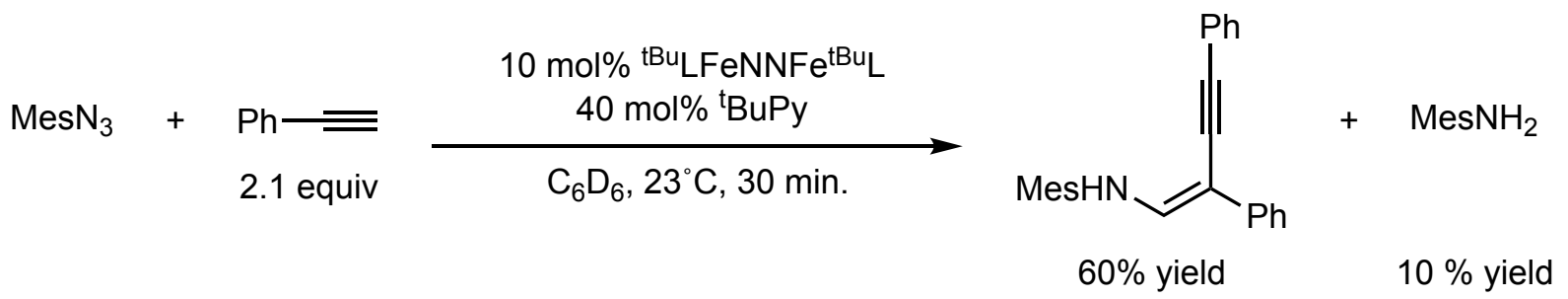

A $20 \mathrm{~mL}$ scintillation vial was loaded with a stir bar and $500 \mu \mathrm{L}$ of a $\mathrm{C}_{6} \mathrm{D}_{6}$ solution of $\mathrm{MesN}_{3}$

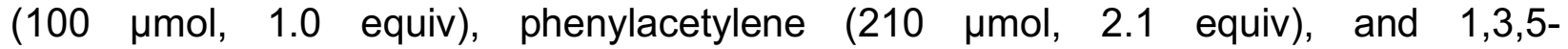
trimethoxybenzene (33 $\mu \mathrm{mol}, 0.33$ equiv) as an internal standard. $6.0 \mu \mathrm{L}(41 \mu \mathrm{mol}, 0.4$ equiv) of ${ }^{\mathrm{t} B u P y}$ was added. $500 \mu \mathrm{L}$ of a $\mathrm{C}_{6} \mathrm{D}_{6}$ solution of ${ }^{\mathrm{BBu}} \mathrm{LFeNNFe} \mathrm{e}^{\mathrm{tBu}} \mathrm{L}(10 \mu \mathrm{mol}, 0.1$ equiv) was added while stirring. The mixture was stirred for 30 minutes at room temperature, then was treated with $\mathrm{H}_{2} \mathrm{~S}$ and filtered through Celite. Analysis by ${ }^{1} \mathrm{H}$ NMR 
spectroscopy indicated the formation of $\mathbf{3 a}$ in $60 \%$ yield, as well as a $10 \%$ yield of MesNH${ }_{2}$.

\section{General procedure for the catalytic reaction with 40 mol\% tBuPy to form $3 b-3 e$.

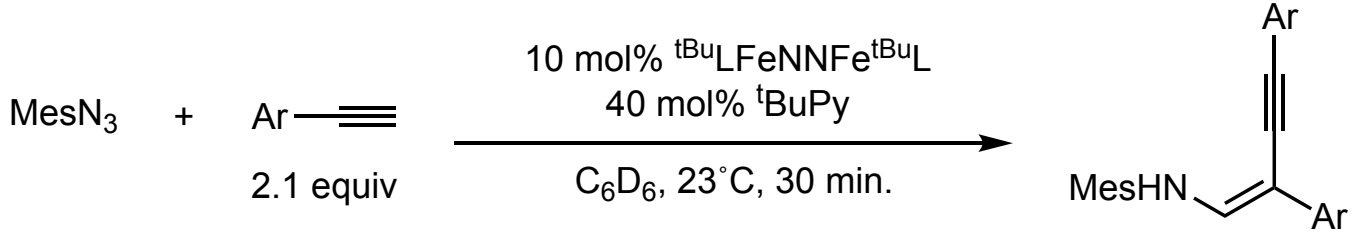

$3 b-3 e$

A $20 \mathrm{~mL}$ scintillation vial was loaded with a stir bar and $600 \mu \mathrm{L}$ of a $\mathrm{C}_{6} \mathrm{D}_{6}$ solution of $\mathrm{MesN}_{3}$ (133 $\mu \mathrm{mol}, 1.0$ equiv), arylacetylene ( $279 \mu \mathrm{mol}, 2.1$ equiv), and 1,3,5-trimethoxybenzene ( $44.3 \mu \mathrm{mol}, 0.33$ equiv) as an internal standard. $7.2 \mathrm{mg}(53 \mu \mathrm{mol}, 0.4$ equiv) of 'BuPy was

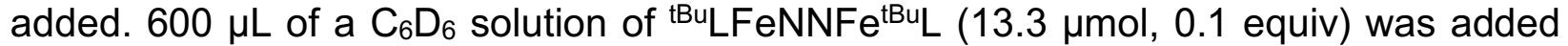
while stirring. The mixture was stirred for 30 minutes at room temperature and analyzed by ${ }^{1} \mathrm{H}$ NMR spectroscopy.

\section{E. Catalytic reaction with $\mathbf{4 0}$ mol\% Py.}

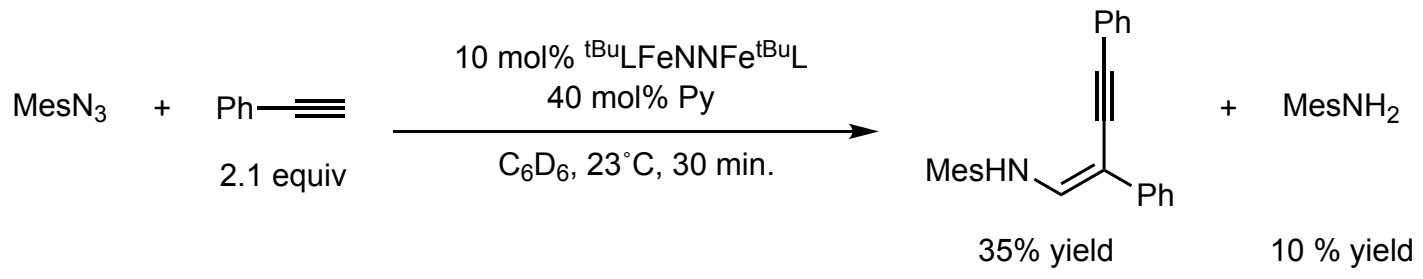

A $20 \mathrm{~mL}$ scintillation vial was loaded with a stir bar and $500 \mu \mathrm{L}$ of a $\mathrm{C}_{6} \mathrm{D}_{6}$ solution of $\mathrm{MesN}_{3}$ (100 $\mu \mathrm{mol}, 1.0$ equiv), phenylacetylene $(210 \mu \mathrm{mol}, 2.1$ equiv), and 1,3,5trimethoxybenzene (33 $\mu \mathrm{mol}, 0.33$ equiv) as an internal standard. $3.3 \mu \mathrm{L}(41 \mu \mathrm{mol}, 0.4$ equiv) of Py was added. $500 \mu \mathrm{L}$ of a $\mathrm{C}_{6} \mathrm{D}_{6}$ solution of $\mathrm{tBu}_{\mathrm{LFeNNFe}}{ }^{\mathrm{tBu} L} \mathrm{~L}(10 \mu \mathrm{mol}, 0.1$ equiv) was added while stirring. The mixture was stirred for 30 minutes at room temperature, then was treated with $\mathrm{H}_{2} \mathrm{~S}$ and filtered through Celite. Analysis by ${ }^{1} \mathrm{H}$ NMR spectroscopy indicated the formation of $3 \mathbf{a}$ in $35 \%$ yield, as well as a $10 \%$ yield of $\mathrm{MesNH}_{2}$.

\section{F. Isolation of ${ }^{\mathrm{tBu}} \mathrm{LFeCCPh}(\mathrm{Py})(7)$ from the catalytic reaction.}

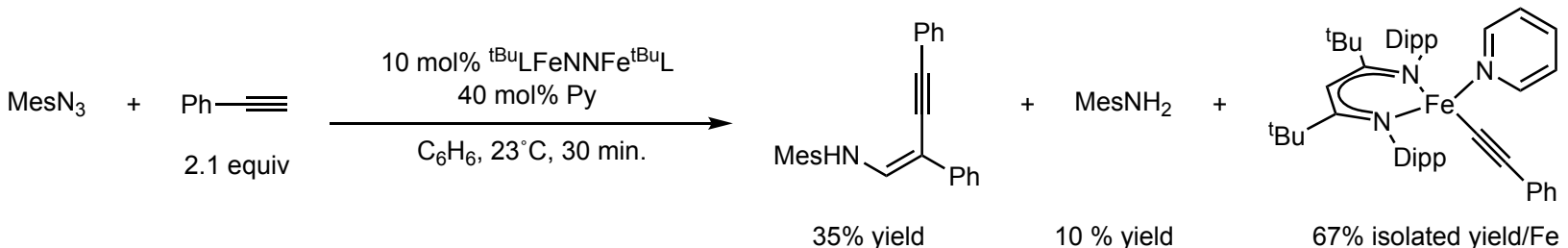

A $20 \mathrm{~mL}$ scintillation vial was loaded with $50 \mathrm{mg}$ ( $44 \mu \mathrm{mol}, 0.1$ equiv) of tBu $L F e N N F e^{\mathrm{tBu}} \mathrm{L}$, $70 \mathrm{mg}$ (440 $\mu \mathrm{mol}, 1.0$ equiv) $\mathrm{MesN}_{3}, 2 \mathrm{~mL}$ benzene, and a stir bar. To the stirring solution was added a solution of $90 \mathrm{mg} \mathrm{(} 880 \mu \mathrm{mol}, 2.0$ equiv) phenylacetylene, $10 \mathrm{mg}(131 \mu \mathrm{mol}$, 0.3 equiv) of pyridine, and $2.3 \mathrm{~mL}$ benzene. The reaction mixture was stirred for 30 minutes at room temperature, and then the volatiles were removed under vacuum. The resulting oil was triturated with pentane and stirred until solids formed. The volatiles were removed under vacuum. This procedure was repeated twice until an orange solid formed. 
The solid was dissolved in $1 \mathrm{~mL}$ of pentane and cooled to $-35^{\circ} \mathrm{C}$ overnight. The solid was collected by filtration, washed with an additional $1 \mathrm{~mL}$ of cold pentane, then dissolved in $\mathrm{Et}_{2} \mathrm{O}$. The volatiles were removed from the $\mathrm{Et}_{2} \mathrm{O}$ filtrate under vacuum to give $43 \mathrm{mg}(67 \%$ yield with respect to $\mathrm{Fe}$ ) of ${ }^{\mathrm{tBu}} \mathrm{LFeCCPh}(\mathrm{Py})$ as a bright orange solid. Crystals suitable for $\mathrm{X}$-ray diffraction were obtained from a saturated pentane solution at $-35^{\circ} \mathrm{C}$.

\section{G. Isolation of $3 a$.}

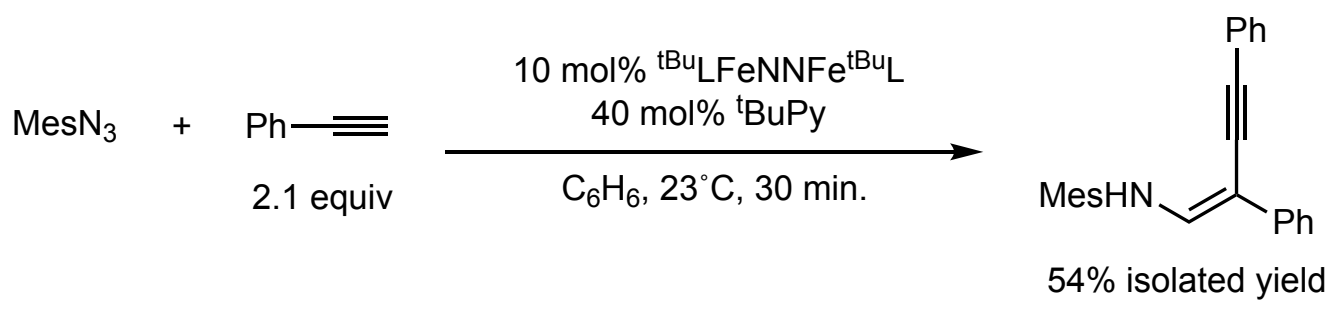

A $20 \mathrm{~mL}$ scintillation vial was loaded with $75 \mathrm{mg}$ (66 $\mu \mathrm{mol}, 0.1$ equiv) of tBuLFeNNFe ${ }^{\mathrm{tBu}} \mathrm{L}$, $5 \mathrm{~mL}$ of benzene, and a stir bar. A solution of $106 \mathrm{mg}\left(656 \mu \mathrm{mol}, 1\right.$ equiv) of $\mathrm{MesN}_{3}, 141$ $\mathrm{mg}$ ( $1.38 \mathrm{mmol}, 2.1$ equiv) of phenylacetylene, $36 \mathrm{mg}$ ( $263 \mu \mathrm{mol}, 0.4$ equiv) of tBuPy in $1.6 \mathrm{~mL}$ of benzene was prepared and added to the vial. The mixture was allowed to stir for 30 minutes at room temperature. The reaction mixture was then transferred to a 25 $\mathrm{mL}$ round bottom flask. The flask was sealed with a septum and removed from the drybox. The reaction mixture was treated with $\mathrm{H}_{2} \mathrm{~S}$ via a balloon and allowed to stir for 30 minutes at room temperature. A black solid formed immediately after $\mathrm{H}_{2} \mathrm{~S}$ addition and the solution took on a green-yellow color. The balloon was removed and any remaining $\mathrm{H}_{2} \mathrm{~S}$ was removed by purging with nitrogen for 10 minutes. The solids were then removed by filtering through Celite, and the volatiles were removed under vacuum. The resulting yellow oil was then gently heated under vacuum $\left(1 \mathrm{mTorr}, 40^{\circ} \mathrm{C}\right)$ overnight. At this point, $3 a$ is contaminated with only ${ }^{\mathrm{B} u} \mathrm{LH}$ and is of sufficient purity to undergo copper-catalyzed cyclization (vide infra). To remove ${ }^{\mathrm{tBu}} \mathrm{LH}$, the oil was treated with $1 \mathrm{~mL}$ of acetonitrile and cooled to $-35^{\circ} \mathrm{C}$ to form bright crystals that were removed by filtration through Celite. The volatiles were removed from the filtrate under vacuum, and then the oil was treated with $1 \mathrm{~mL}$ of pentane and cooled to $-35^{\circ} \mathrm{C}$, whereupon more solids formed. After filtration through Celite, 3a was obtained as a dark yellow-orange oil, $119 \mathrm{mg}, 54 \%$ yield. ${ }^{1} \mathrm{H}$ NMR (400 MHz, $\left.\mathrm{C}_{6} \mathrm{D}_{6}\right): \delta 7.62(\mathrm{~d}, J=7.3 \mathrm{~Hz}, 2 \mathrm{H}), 7.46(\mathrm{~d}, J=6.7 \mathrm{~Hz}, 2 \mathrm{H}), 7.23(\mathrm{t}, J=7.8 \mathrm{~Hz}$, $2 \mathrm{H}), 7.04(\mathrm{~m}, 5 \mathrm{H}), 6.70(\mathrm{~s}, 2 \mathrm{H}), 6.26(\mathrm{~d}, J=12.7 \mathrm{~Hz}, 1 \mathrm{H}), 2.13(\mathrm{~s}, 3 \mathrm{H}), 2.10(\mathrm{~s}, 6 \mathrm{H}) .{ }^{13} \mathrm{C}$ $\operatorname{NMR}\left(100 \mathrm{MHz} ; \mathrm{C}_{6} \mathrm{D}_{6}\right) \delta 140.61,138.06,137.01,134.24,131.84,131.36,129.52,128.67$, $128.45,125.07,124.48,124.20,98.17,94.25,86.52,20.63,18.30$. GC-MS (EI) m/z (\%): 338 (28.2), 337 (100.0), 336 (14.7).

\section{H. Copper(I)-catalyzed cyclization of 3a.}

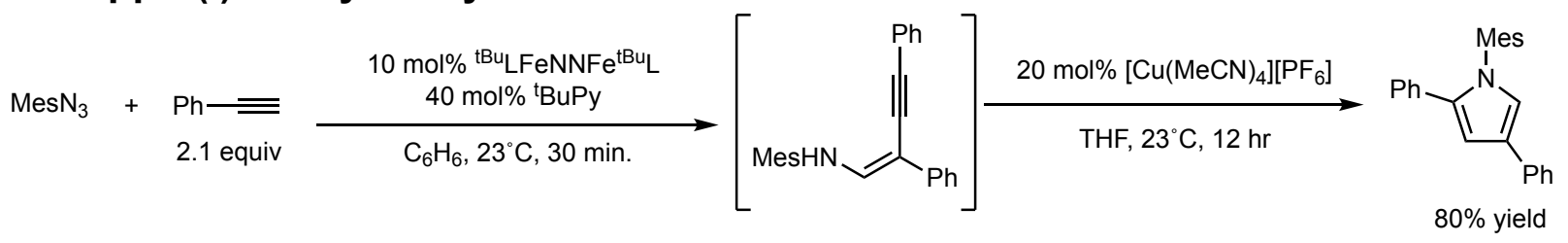

A $20 \mathrm{~mL}$ scintillation vial was loaded with $75 \mathrm{mg}\left(66 \mu \mathrm{mol}, 0.1\right.$ equiv) of tBuLFeNNFe ${ }^{\mathrm{tBu}} \mathrm{L}$, $5 \mathrm{~mL}$ of benzene, and a stir bar. A solution of $106 \mathrm{mg}\left(656 \mu \mathrm{mol}, 1\right.$ equiv) of $\mathrm{MesN}_{3}, 141$ $\mathrm{mg}$ ( $1.38 \mathrm{mmol}, 2.1$ equiv) of phenylacetylene, $36 \mathrm{mg}$ ( $263 \mu \mathrm{mol}, 0.4$ equiv) of 'BuPy in 
$1.6 \mathrm{~mL}$ of benzene was prepared and added to the vial. The mixture was allowed to stir for 30 minutes at room temperature. The reaction mixture was then transferred to a 25 $\mathrm{mL}$ round bottom flask. The flask was sealed with a septum and removed from the drybox. The reaction mixture was treated with $\mathrm{H}_{2} \mathrm{~S}$ via a balloon and allowed to stir for 30 minutes at room temperature. A black solid formed immediately after $\mathrm{H}_{2} \mathrm{~S}$ addition and the solution took on a green-yellow color. The balloon was removed and any remaining $\mathrm{H}_{2} \mathrm{~S}$ was removed by purging with nitrogen for 10 minutes. The solids were then removed by filtering through Celite, and the volatiles were removed under vacuum. The resulting yellow oil was then gently heated under vacuum $\left(1 \mathrm{mTorr}, 40^{\circ} \mathrm{C}\right)$ overnight. The oil $(176$ $\mathrm{mg}$ ) was dissolved in $5 \mathrm{~mL}$ of THF to give a yellow solution. To this solution was added $29 \mathrm{mg}\left[\mathrm{Cu}(\mathrm{MeCN})_{4}\right]\left[\mathrm{PF}_{6}\right]\left(79 \mu \mathrm{mol}, 0.12\right.$ equiv based on $\mathrm{MesN}_{3}, 0.2$ equiv based on a $60 \%$ yield of $3 a$ ), resulting in a color change from yellow to red. The solution was stirred overnight at room temperature, and then the volatiles were removed under vacuum. The resulting solid was taken out of the drybox and purified by column chromatography (10:1 hexanes : ethyl acetate) to give $106 \mathrm{mg}$ (80\% yield) of 1-mesityl-2,4-diphenyl-1 $\mathrm{H}$-pyrrole as a yellow solid contaminated with remaining ${ }^{\mathrm{BB}} \mathrm{LH}$. ${ }^{1} \mathrm{H}$ NMR matched the literature. ${ }^{12}{ }^{1} \mathrm{H}$ NMR (400 MHz; $\left.\mathrm{CD}_{2} \mathrm{Cl}_{2}\right)$ : $\delta 7.62$ (d, $\left.J=7.2 \mathrm{~Hz}, 2 \mathrm{H}\right), 7.37(\mathrm{t}, J=7.7 \mathrm{~Hz}, 2 \mathrm{H}), 7.22-7.15$ $(\mathrm{m}, 6 \mathrm{H}), 6.98(\mathrm{~d}, J=2.0 \mathrm{~Hz}, 1 \mathrm{H}), 6.95(\mathrm{~s}, 2 \mathrm{H}), 6.86(\mathrm{~d}, J=2.0 \mathrm{~Hz}, 1 \mathrm{H}), 2.34(\mathrm{~s}, 3 \mathrm{H}), 2.00$ $(\mathrm{s}, 6 \mathrm{H})$.

\section{General procedure for the preparation and cyclization of $3 b-3 e$.}

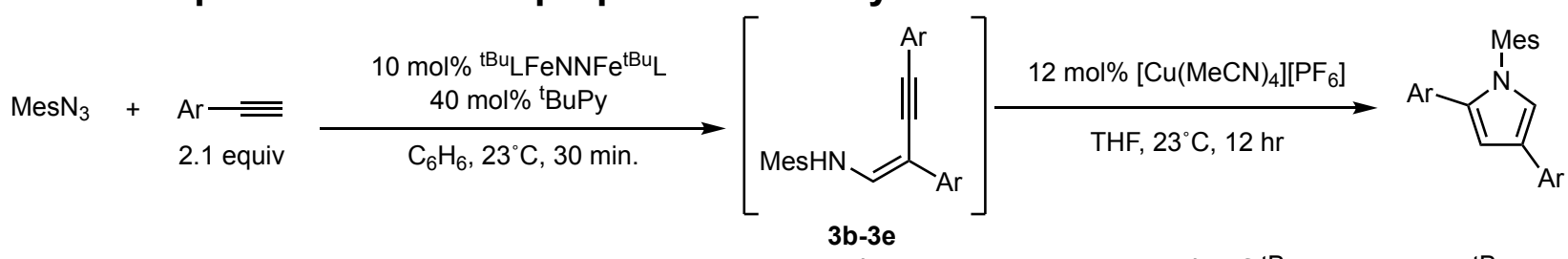

A $20 \mathrm{~mL}$ scintillation vial was loaded with $50 \mathrm{mg}$ ( $44 \mu \mathrm{mol}, 0.1$ equiv) of tBuLFeNNFe ${ }^{\mathrm{tBu}} \mathrm{L}$, $2.2 \mathrm{~mL}$ of benzene, and a stir bar. A solution of $70 \mathrm{mg}\left(437 \mu \mathrm{mol}, 1\right.$ equiv) of $\mathrm{MesN}_{3}$, $1.38 \mathrm{mmol}$ (2.1 equiv) of arylacetylene, $24 \mathrm{mg}$ ( $263 \mu \mathrm{mol}, 0.4$ equiv) of ${ }^{\mathrm{t}} \mathrm{BuPy}$ in $2.2 \mathrm{~mL}$ of benzene was prepared and added to the vial. The mixture was allowed to stir for 30 minutes at room temperature. The reaction mixture was then transferred to a $25 \mathrm{~mL}$ round bottom flask. The flask was sealed with a septum and removed from the drybox. The reaction mixture was treated with $\mathrm{H}_{2} \mathrm{~S}$ via a balloon and allowed to stir for 30 minutes at room temperature. A black solid formed immediately after $\mathrm{H}_{2} \mathrm{~S}$ addition and the solution took on a green-yellow color. The balloon was removed and any remaining $\mathrm{H}_{2} \mathrm{~S}$ was removed by purging with nitrogen for 10 minutes. The solids were then removed by filtering through Celite, and the volatiles were removed under vacuum. The resulting yellow oil was then gently heated under vacuum $\left(1 \mathrm{mTorr}, 40^{\circ} \mathrm{C}\right)$ overnight. The oil was then dissolved in $5 \mathrm{~mL}$ of THF to give a yellow solution. To this solution was added $20 \mathrm{mg}$ [Cu( $\left.\mathrm{MeCN})_{4}\right]\left[\mathrm{PF}_{6}\right]\left(53 \mu \mathrm{mol}, 0.12\right.$ equiv based on $\left.\mathrm{MesN}_{3}\right)$ resulting in a color change from yellow to red. The solution was stirred overnight at room temperature, and then the volatiles were removed under vacuum. The resulting oil was taken out of the drybox and purified by column chromatography.

\section{1-mesityl-2,4-bis(4-methoxyphenyl)-1H-pyrrole}


A second addition of $12 \mathrm{~mol} \%$ [ $\left.\mathrm{Cu}(\mathrm{MeCN})_{4}\right]\left[\mathrm{PF}_{6}\right]$ was necessary for complete conversion. Eluted with 20:1 hexanes:ethyl acetate and isolated as an off-white solid. Yield: $66 \mathrm{mg}, 38 \%$ yield (2 steps). ${ }^{1} \mathrm{H}$ NMR $\left(400 \mathrm{MHz}, \mathrm{CDCl}_{3}\right): \delta 7.52$ (apparent d, $J=$ $8.8 \mathrm{~Hz}, 2 \mathrm{H}$ ), 7.05 (apparent d, J = 8.8 Hz, 2H), 6.92 (apparent d, $J=8.8 \mathrm{~Hz}, 2 \mathrm{H}$ ), 6.90 (s, 2H), $6.82(\mathrm{~s}, 1 \mathrm{H}), 6.72$ (apparent d, J = 8.8 Hz, 2H), $6.69(\mathrm{~s}, 1 \mathrm{H}), 3.83(\mathrm{~s}, 3 \mathrm{H}), 3.75$ (s, 3H), 2.32 (s, 3H), 1.98 (s, 6H). ${ }^{13} \mathrm{C}$ NMR $\left(100 \mathrm{MHz} ; \mathrm{CDCl}_{3}\right) \delta$ 158.2, 157.9, 137.9, 136.7, 136.2, 134.9, 129.0, 128.6, 127.9, 126.1, 126.1, 124.9, 118.8, 114.3, 113.8, 105.3, 55.50, 55.27, 21.22, 17.96. GC-MS (EI) m/z (\%): 399 (5.3), 398 (30.4), 397 (100.0), 396 (5.6).

\section{1-mesityl-2,4-bis(4-tolyl)-1H-pyrrole}

Eluted with hexanes and isolated as a yellow oil. Yield: $57 \mathrm{mg}, 36 \%$ yield (2 steps). Characterized as a 3.6:1 mixture with ${ }^{\mathrm{BBu}} \mathrm{LH} .{ }^{1} \mathrm{H}$ NMR $\left(400 \mathrm{MHz} ; \mathrm{CDCl}_{3}\right): \delta 7.56(\mathrm{~d}, \mathrm{~J}=$ $8.1 \mathrm{~Hz}, 2 \mathrm{H}), 7.23(\mathrm{~d}, J=7.9 \mathrm{~Hz}, 2 \mathrm{H}), 7.08(\mathrm{~d}, J=8.3 \mathrm{~Hz}, 2 \mathrm{H}), 7.03(\mathrm{~d}, J=8.1 \mathrm{~Hz}, 2 \mathrm{H})$, $6.96(\mathrm{~s}, 2 \mathrm{H}), 6.94(\mathrm{~d}, J=2.0 \mathrm{~Hz}, 1 \mathrm{H}), 6.85(\mathrm{~d}, J=2.0 \mathrm{~Hz}, 1 \mathrm{H}), 2.41(\mathrm{~s}, 3 \mathrm{H}), 2.37(\mathrm{~s}, 3 \mathrm{H})$, $2.32(\mathrm{~s}, 3 \mathrm{H}), 2.05(\mathrm{~s}, 6 \mathrm{H}) .{ }^{13} \mathrm{C} \mathrm{NMR}\left(100 \mathrm{MHz} ; \mathrm{CDCl}_{3}\right): \delta 137.9,136.8,136.1,135.9$, 135.1, 135.0, 132.8, 130.4, 129.5, 129.0, 129.0, 126.4, 125.3, 124.9, 122.6, 119.6, 105.9, 21.2, 21.2, 17.9. GC-MS (EI) m/z (\%): 366 (29.5), 365 (100.0), 364 (12.8).

\section{1-mesityl-2,4-bis(4-fluorophenyl)-1H-pyrrole}

Eluted with hexanes and isolated as a light yellow oil. Yield: $45 \mathrm{mg}, 28 \%$ yield (2 steps). ${ }^{1} \mathrm{H}$ NMR $\left(400 \mathrm{MHz}, \mathrm{CDCl}_{3}\right): \delta 7.57$ (apparent dd, $\left.J=8.4,5.6 \mathrm{~Hz}, 2 \mathrm{H}\right), 7.14-7.06(\mathrm{~m}$, $4 \mathrm{H}), 6.95(\mathrm{~s}, 2 \mathrm{H}), 6.93-6.88(\mathrm{~m}, 3 \mathrm{H}), 6.76(\mathrm{~d}, J=2.0 \mathrm{~Hz}, 1 \mathrm{H}), 2.36(\mathrm{~s}, 3 \mathrm{H}), 2.01(\mathrm{~s}, 6 \mathrm{H})$. ${ }^{13} \mathrm{C}$ NMR $\left(100 \mathrm{MHz} ; \mathrm{CDCl}_{3}\right) \delta 161.7$ (d, $\left.J=244.8 \mathrm{~Hz}\right), 161.4(\mathrm{~d}, J=242.2 \mathrm{~Hz}), 138.3$, 136.2, 136.0, 134.3, 131.7 (d, $J=3.0 \mathrm{~Hz}), 129.2(\mathrm{~d}, J=3.4 \mathrm{~Hz}), 129.2,128.3(\mathrm{~d}, J=7.6$ $\mathrm{Hz}), 126.4(\mathrm{~d}, J=7.8 \mathrm{~Hz}), 124.5,119.8,115.6(\mathrm{~d}, J=21.2 \mathrm{~Hz}), 115.3(\mathrm{~d}, J=21.2 \mathrm{~Hz})$, 106.2, 21.2, 17.9. $\left.{ }^{19} \mathrm{~F} \mathrm{NMR} \mathrm{(376} \mathrm{MHz,} \mathrm{CDCl}_{3}\right):-115.9,-117.7$. GC-MS (EI) m/z (\%): 374 (27.7), 373 (100.0), 372 (12.8).

\section{1-mesityl-2,4-bis(4-trifluoromethylphenyl)-1H-pyrrole}

Eluted with hexanes and isolated as a light yellow oil. Yield: $15 \mathrm{mg}, 7 \%$ yield (2 steps). ${ }^{1} \mathrm{H} \mathrm{NMR}\left(400 \mathrm{MHz}, \mathrm{CDCl}_{3}\right): \delta 7.68(\mathrm{~d}, J=8.0 \mathrm{~Hz}, 2 \mathrm{H}), 7.62(\mathrm{~d}, J=8.0 \mathrm{~Hz}, 2 \mathrm{H}), 7.44$ (d, $J=8.0 \mathrm{~Hz}, 2 \mathrm{H}), 7.22(\mathrm{~d}, J=8.0 \mathrm{~Hz}, 2 \mathrm{H}), 7.05(\mathrm{~s}, 1 \mathrm{H}), 6.95(\mathrm{~s}, 3 \mathrm{H}), 2.35(\mathrm{~s}, 3 \mathrm{H}), 1.98(\mathrm{~s}$, $6 \mathrm{H}) .{ }^{13} \mathrm{C}$ NMR $\left(100 \mathrm{MHz} ; \mathrm{CDCl}_{3} \delta 138.8,136.1,136.1,136.0,135.8,134.0,129.4\right.$, $128.3(q, J=32.5), 127.8(q, J=32.1), 126.3,125.8(q, J=3.7), 125.5(q, J=3.7)$, 125.0, 124.5, 122.2, 107.7, 21.2, 17.9. ${ }^{19} \mathrm{~F} \mathrm{NMR}\left(376 \mathrm{MHz}, \mathrm{CDCl}_{3}\right):-62.3,-62.6$. GC-MS (EI) m/z (\%): 475 (4.6), 474 (28.2), 473 (100.0), 472 (13.7). 


\section{NMR Spectra.}

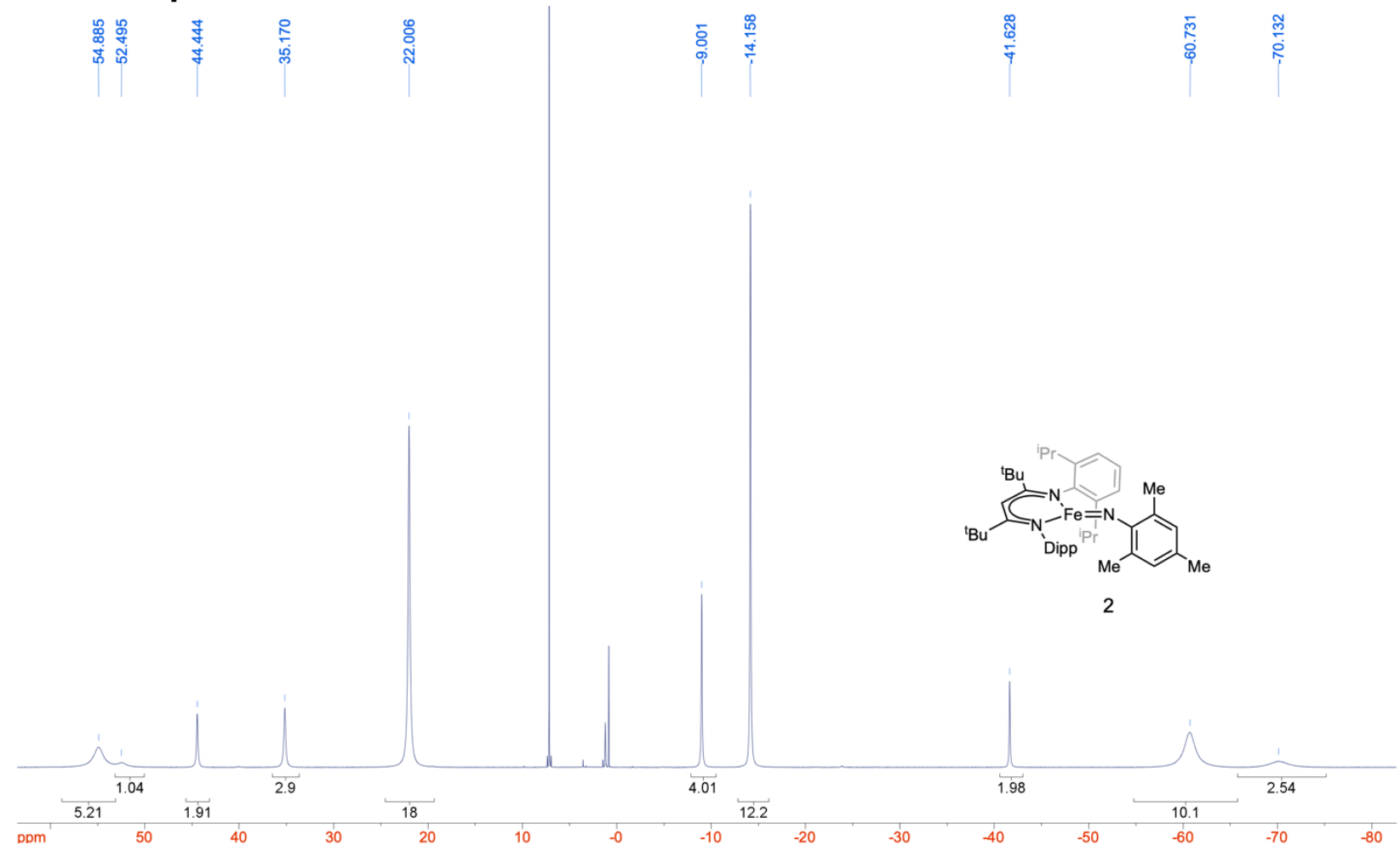

Figure S2. ${ }^{1} \mathrm{H}$ NMR of tBuLFeNMes (2). (400 MHz, $\left.\mathrm{C}_{6} \mathrm{D}_{6}\right)$

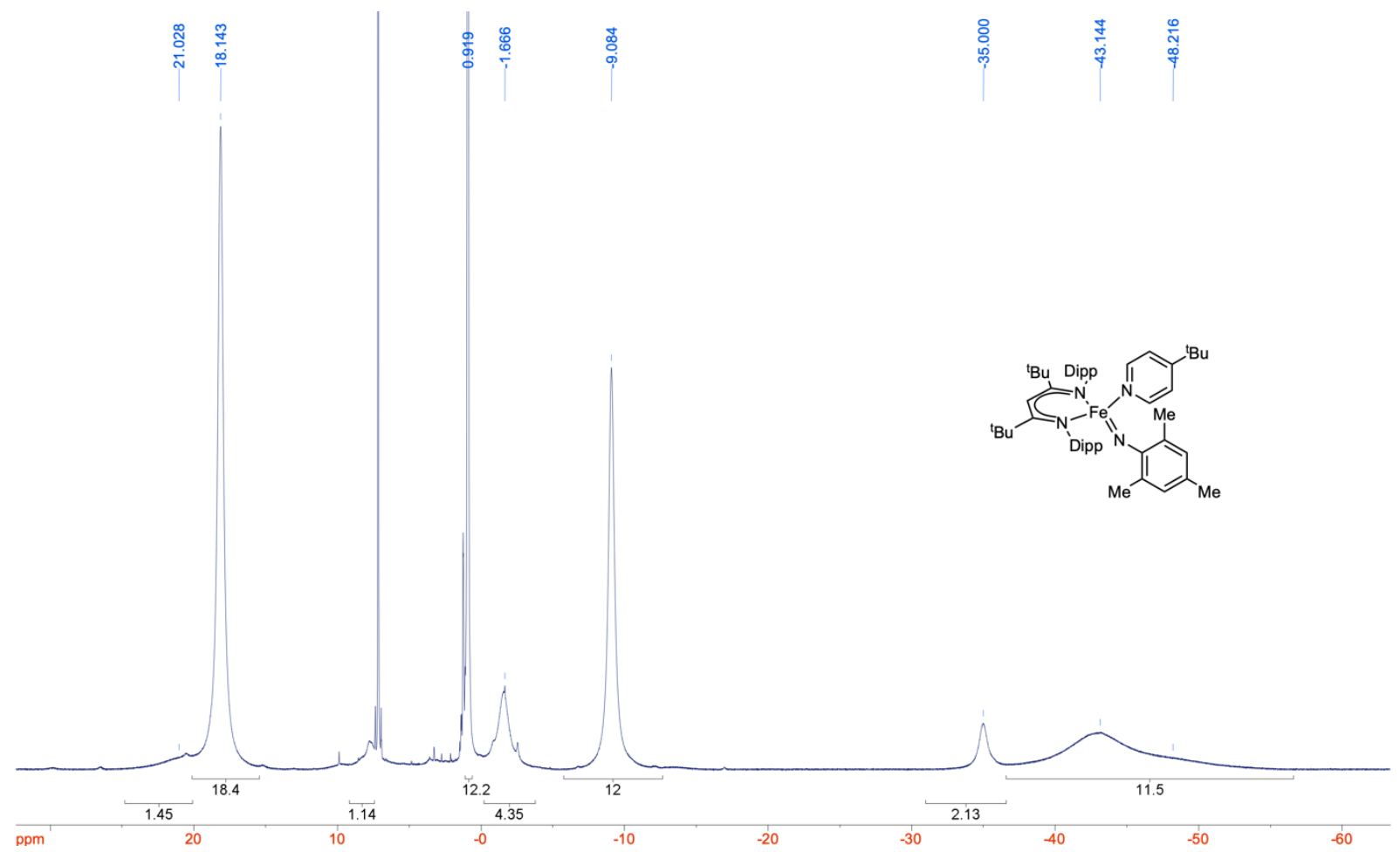

Figure S3. ${ }^{1} \mathrm{H}$ NMR of tBuLFeNMes(tBuPy). (400 MHz, $\left.\mathrm{C}_{6} \mathrm{D}_{6}\right)$ 


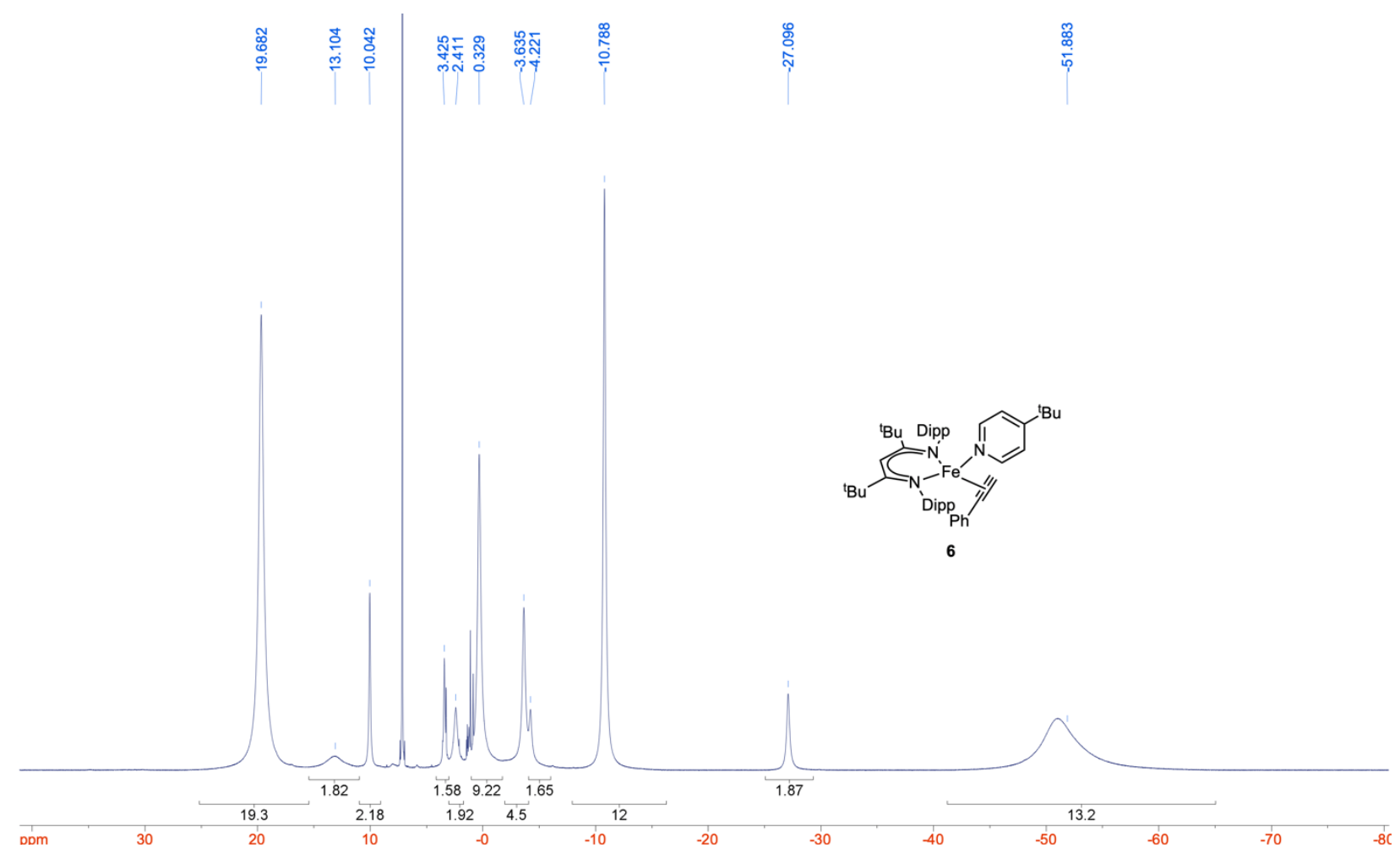

Figure S4. ${ }^{1} \mathrm{H} N M R{ }^{\text {tBu}} \mathrm{LFe}(\mathrm{HCCPh})\left({ }^{\mathrm{B} u P y}\right)(6) .\left(400 \mathrm{MHz}, \mathrm{C}_{6} \mathrm{D}_{6}\right)$

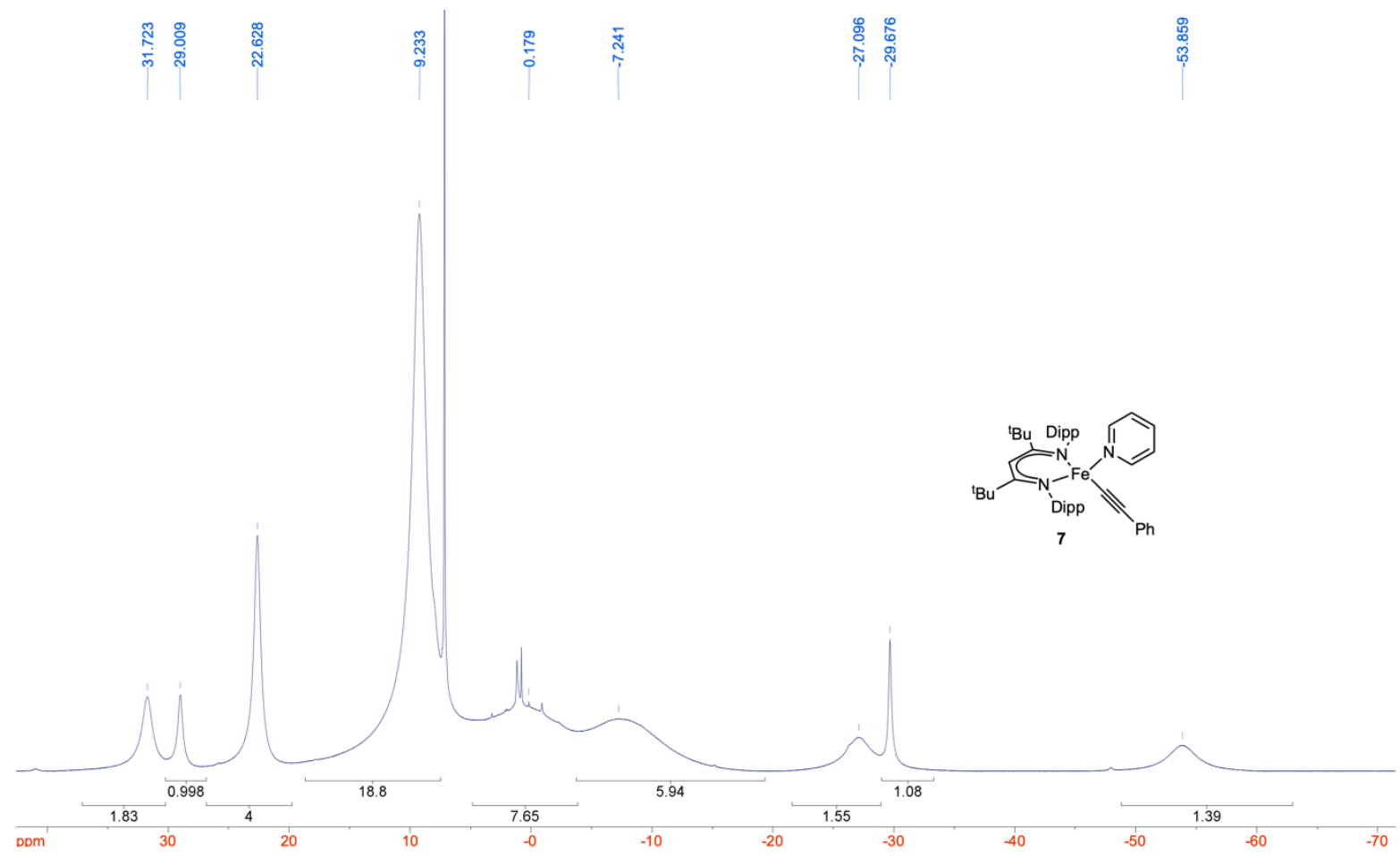

Figure S5. ${ }^{1} \mathrm{H}$ NMR ${ }^{\text {tBu }} \mathrm{LFeCCPh}(\mathrm{Py})(7) .\left(400 \mathrm{MHz}, \mathrm{C}_{6} \mathrm{D}_{6}\right)$ 


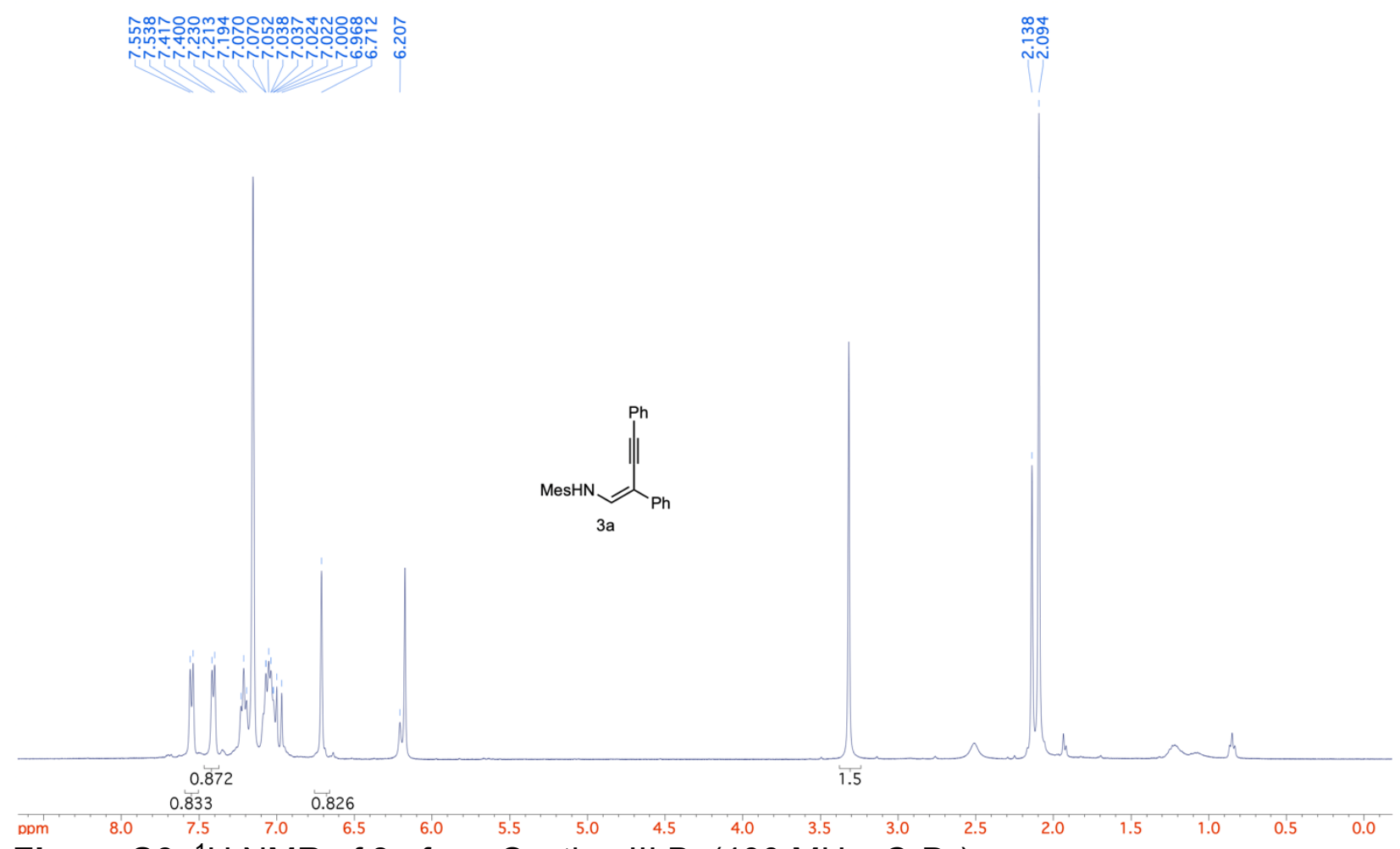

Figure S6. ${ }^{1} \mathrm{H}$ NMR of $3 a$ from Section III.B. $\left(400 \mathrm{MHz}, \mathrm{C}_{6} \mathrm{D}_{6}\right)$

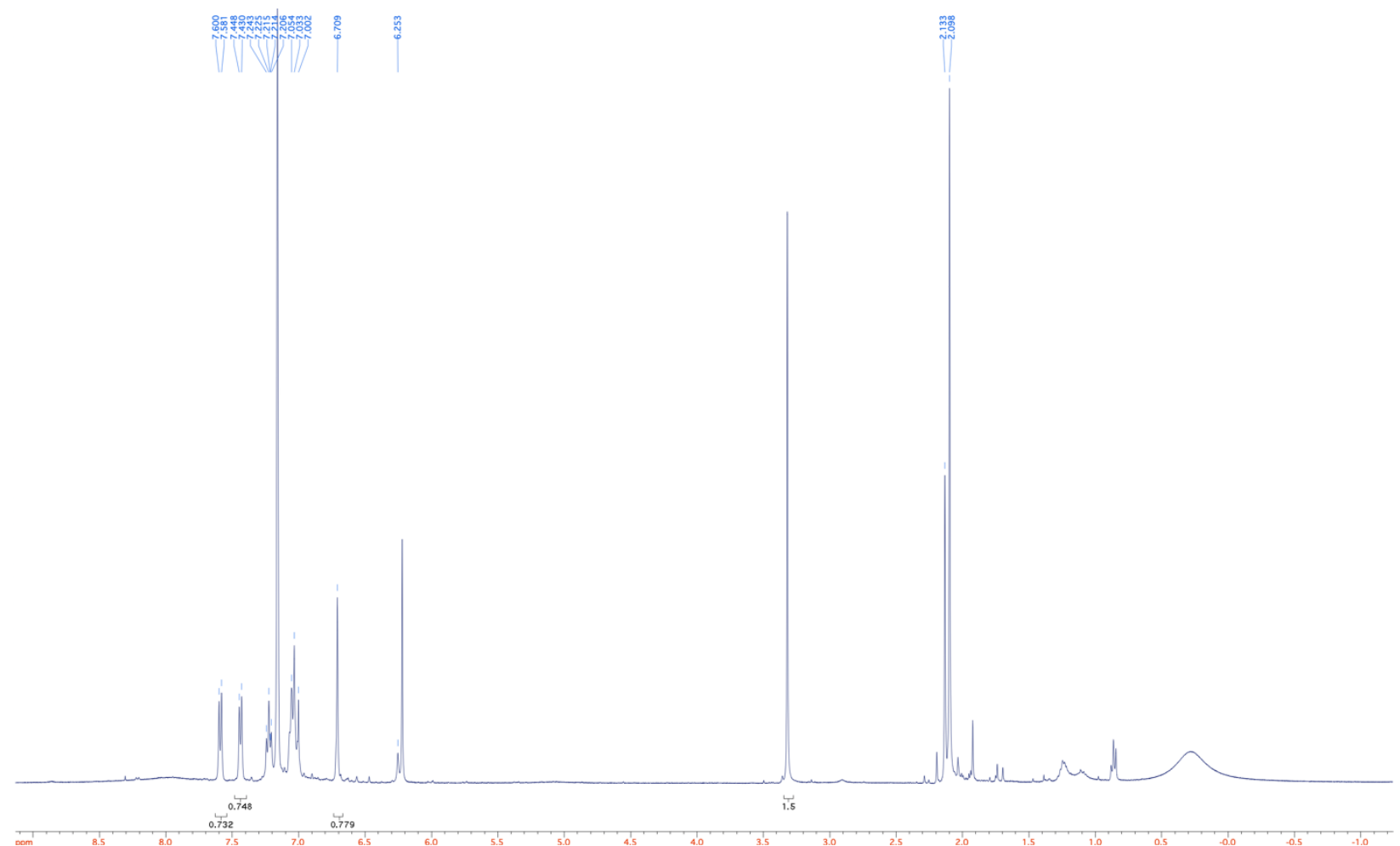

Figure S7. ${ }^{1} \mathrm{H}$ NMR of $3 a$ from Section III.C. $\left(400 \mathrm{MHz}, \mathrm{C}_{6} \mathrm{D}_{6}\right)$ 


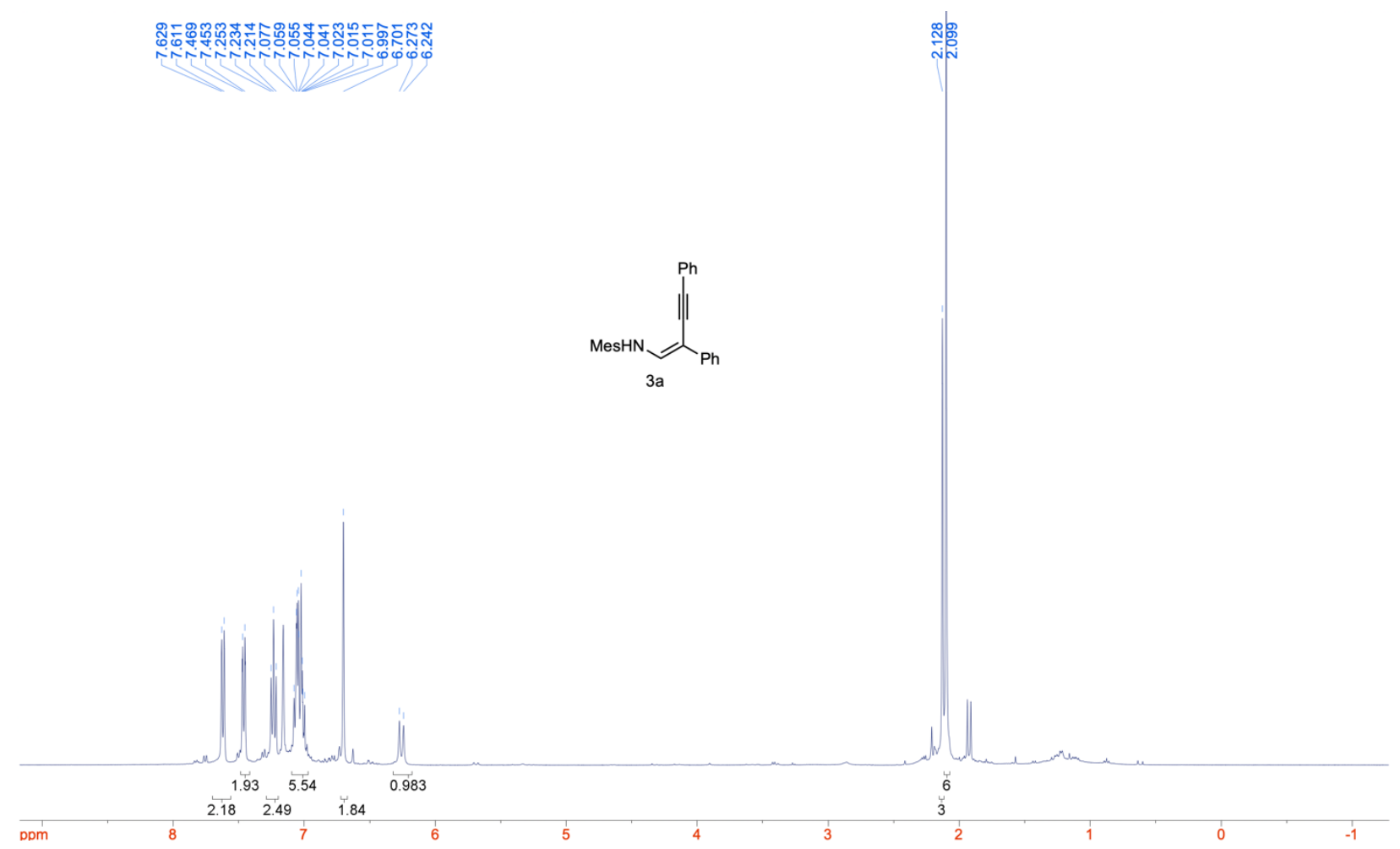

Figure S8. ${ }^{1} \mathrm{H}$ NMR of $3 \mathrm{a}\left(400 \mathrm{MHz}, \mathrm{C}_{6} \mathrm{D}_{6}\right)$

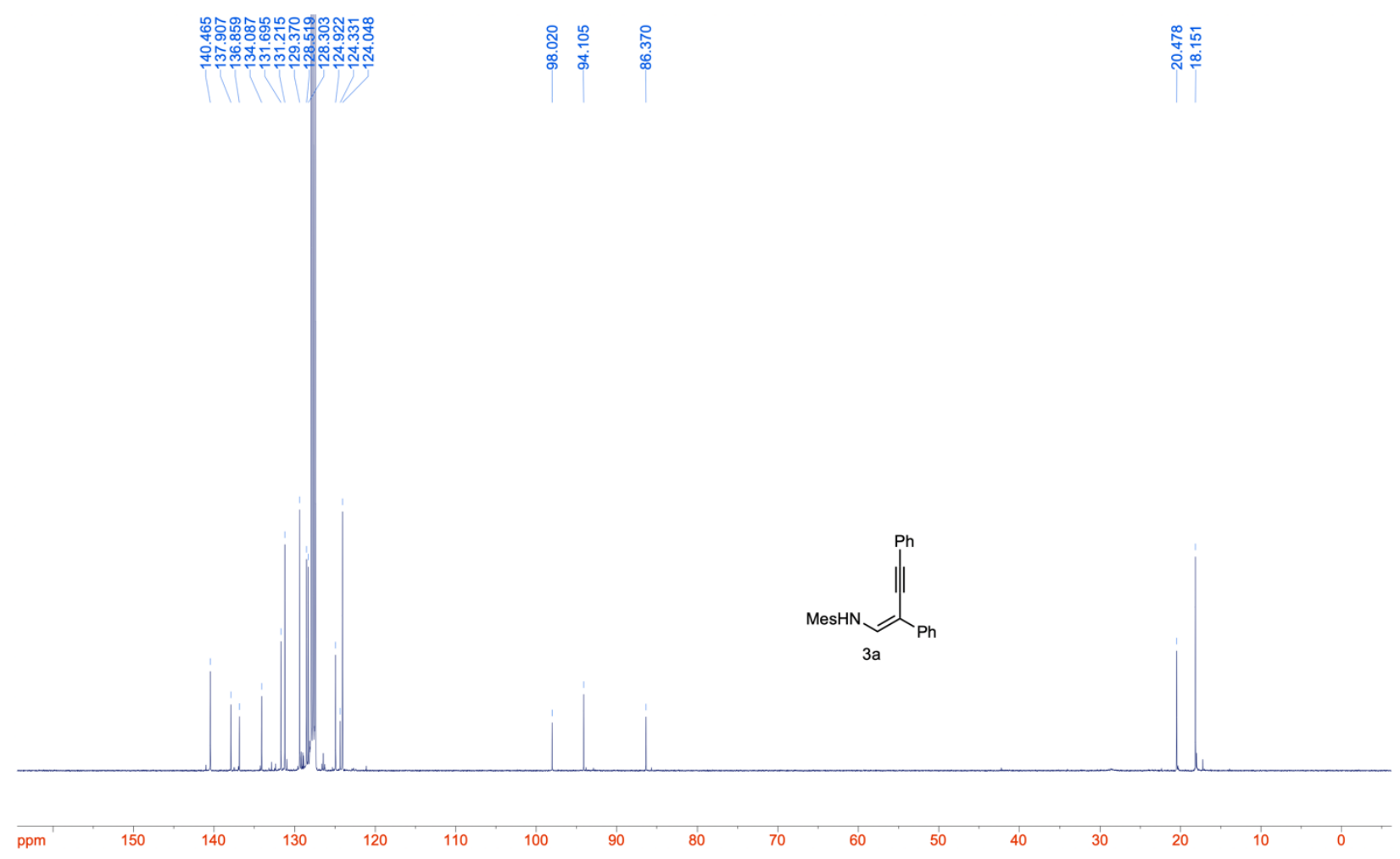

Figure S9. ${ }^{13} \mathrm{C}$ NMR of $3 a\left(100 \mathrm{MHz}, \mathrm{C}_{6} \mathrm{D}_{6}\right)$ 


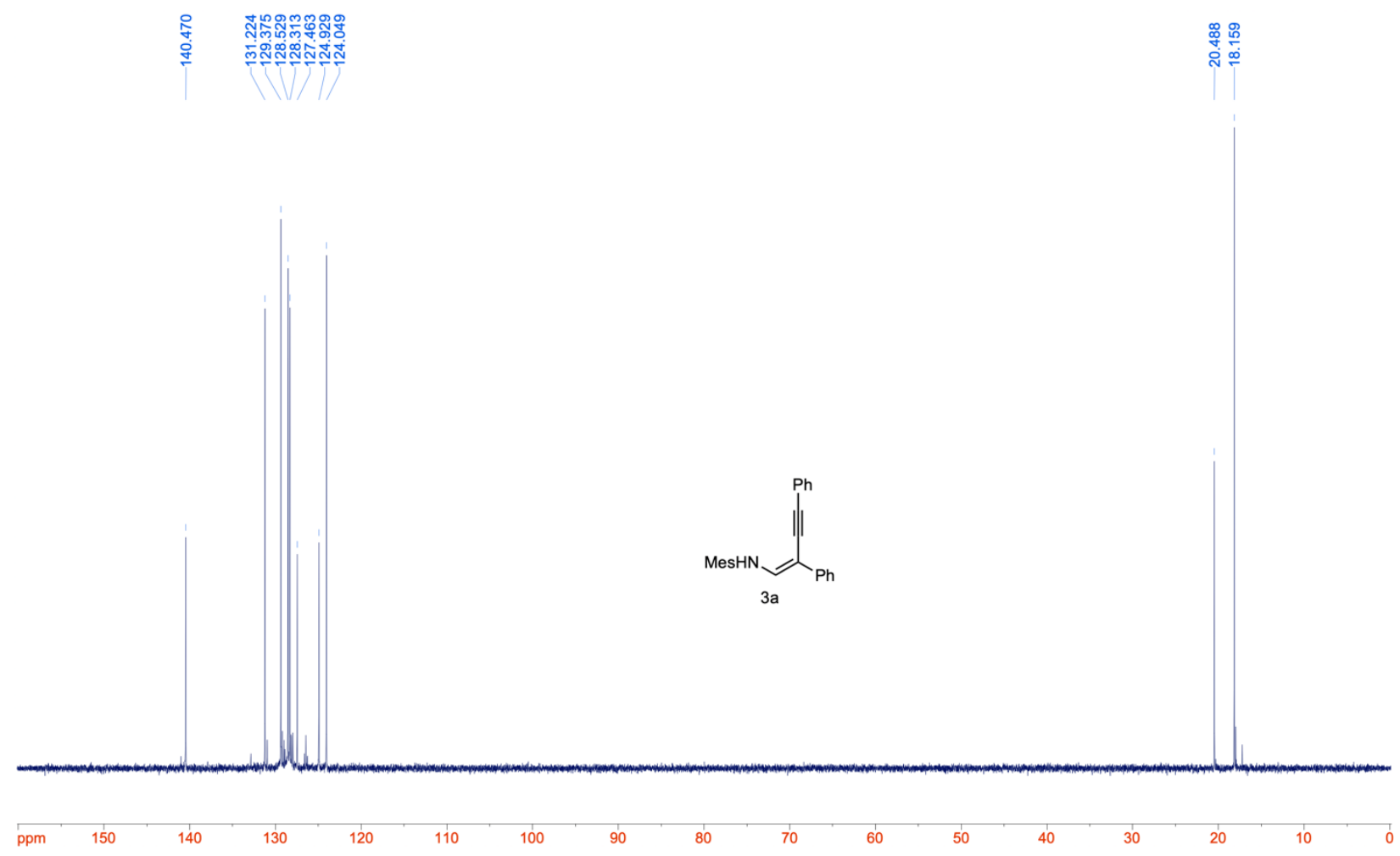

Figure S10. DEPT-135 of $\mathbf{3 a}\left(100 \mathrm{MHz}, \mathrm{C}_{6} \mathrm{D}_{6}\right)$

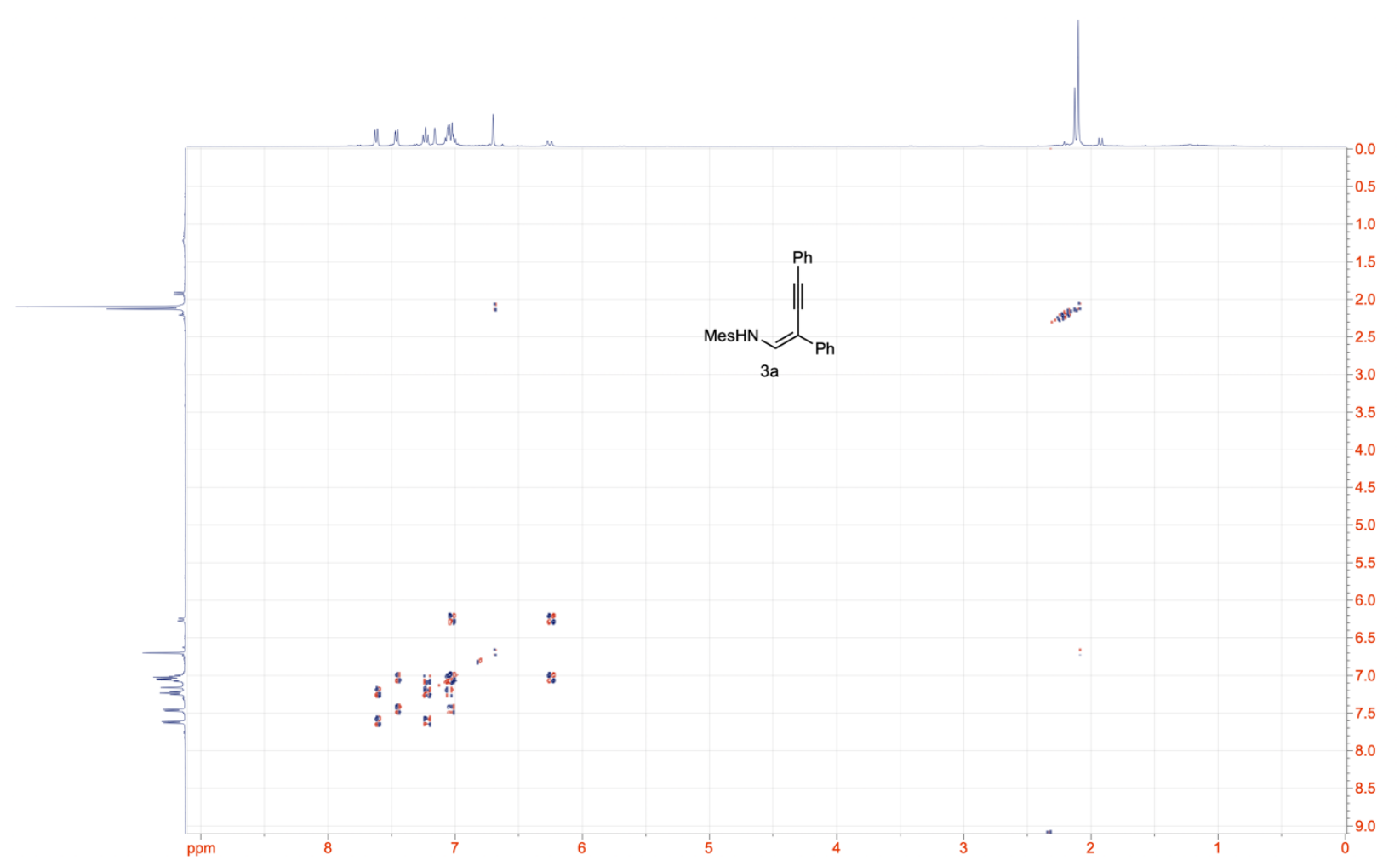

Figure S11. COSY of $3 \mathbf{a}\left(400 \mathrm{MHz}, \mathrm{C}_{6} \mathrm{D}_{6}\right)$ 


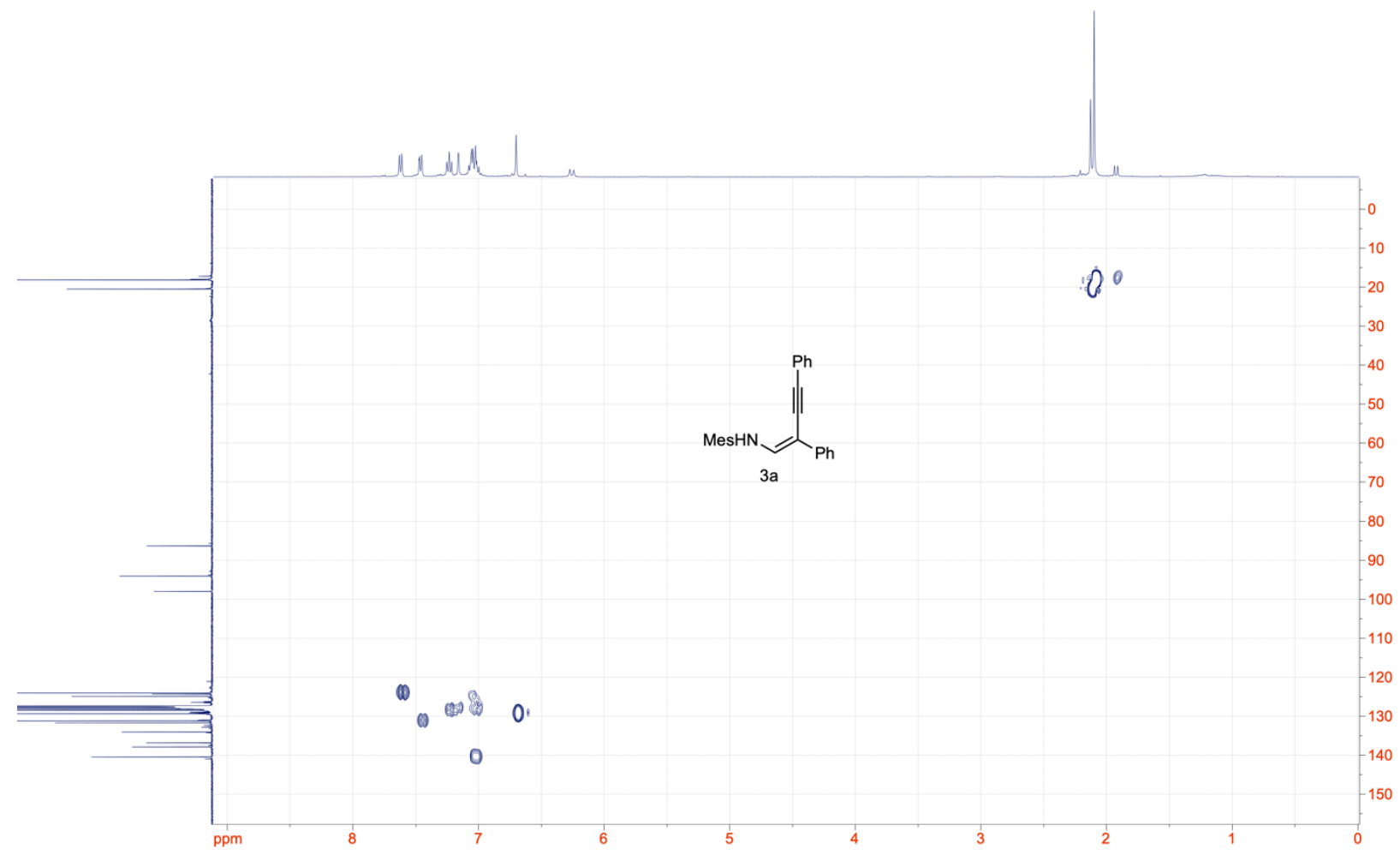

Figure $\mathbf{S} 12 .{ }^{1} \mathrm{H}-{ }^{13} \mathrm{C} H M Q C$ of $3 \mathbf{a}\left(400 \mathrm{MHz}, \mathrm{C}_{6} \mathrm{D}_{6}\right)$

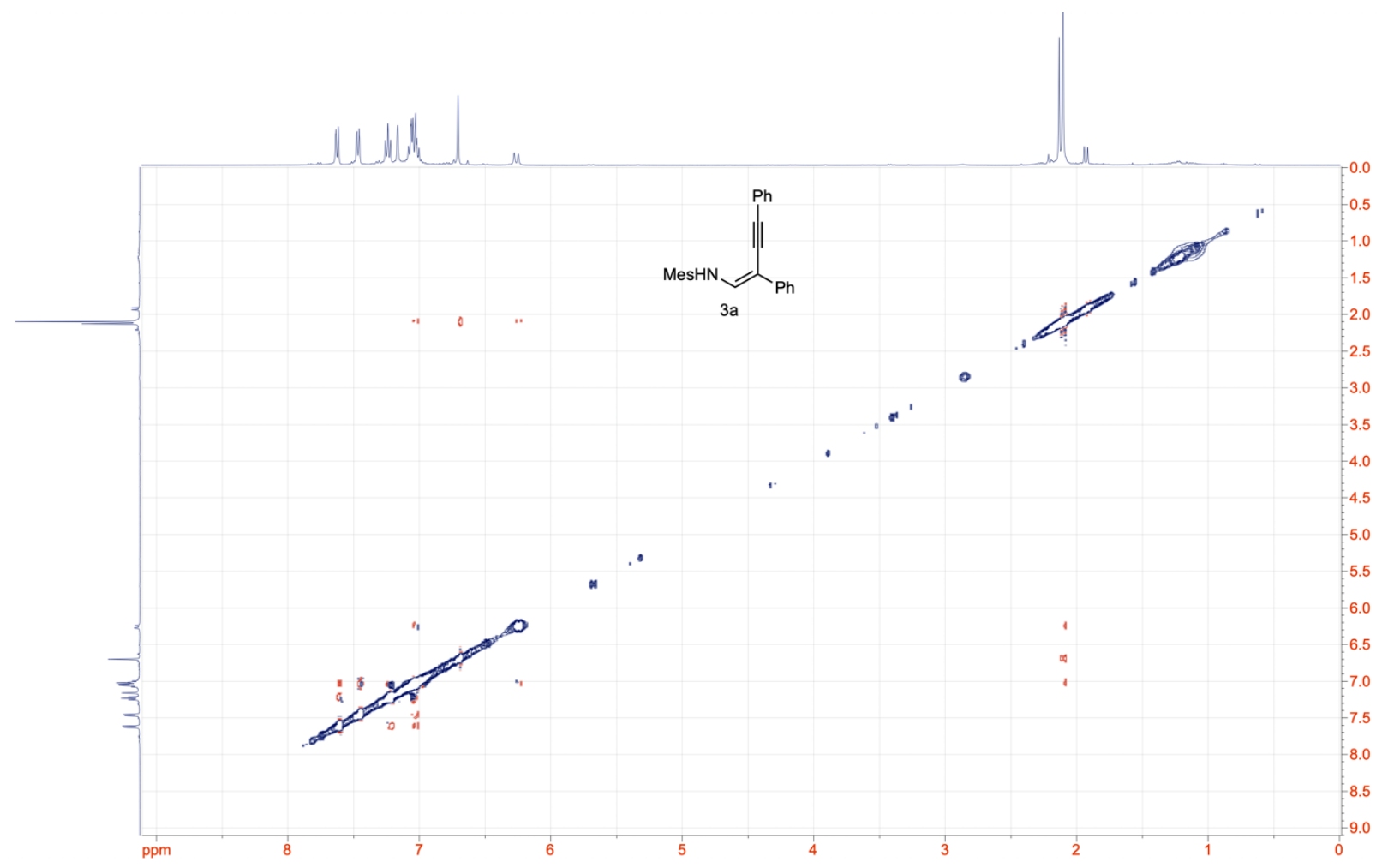

Figure S13. NOESY of $\mathbf{3 a}\left(400 \mathrm{MHz}, \mathrm{C}_{6} \mathrm{D}_{6}\right)$ 


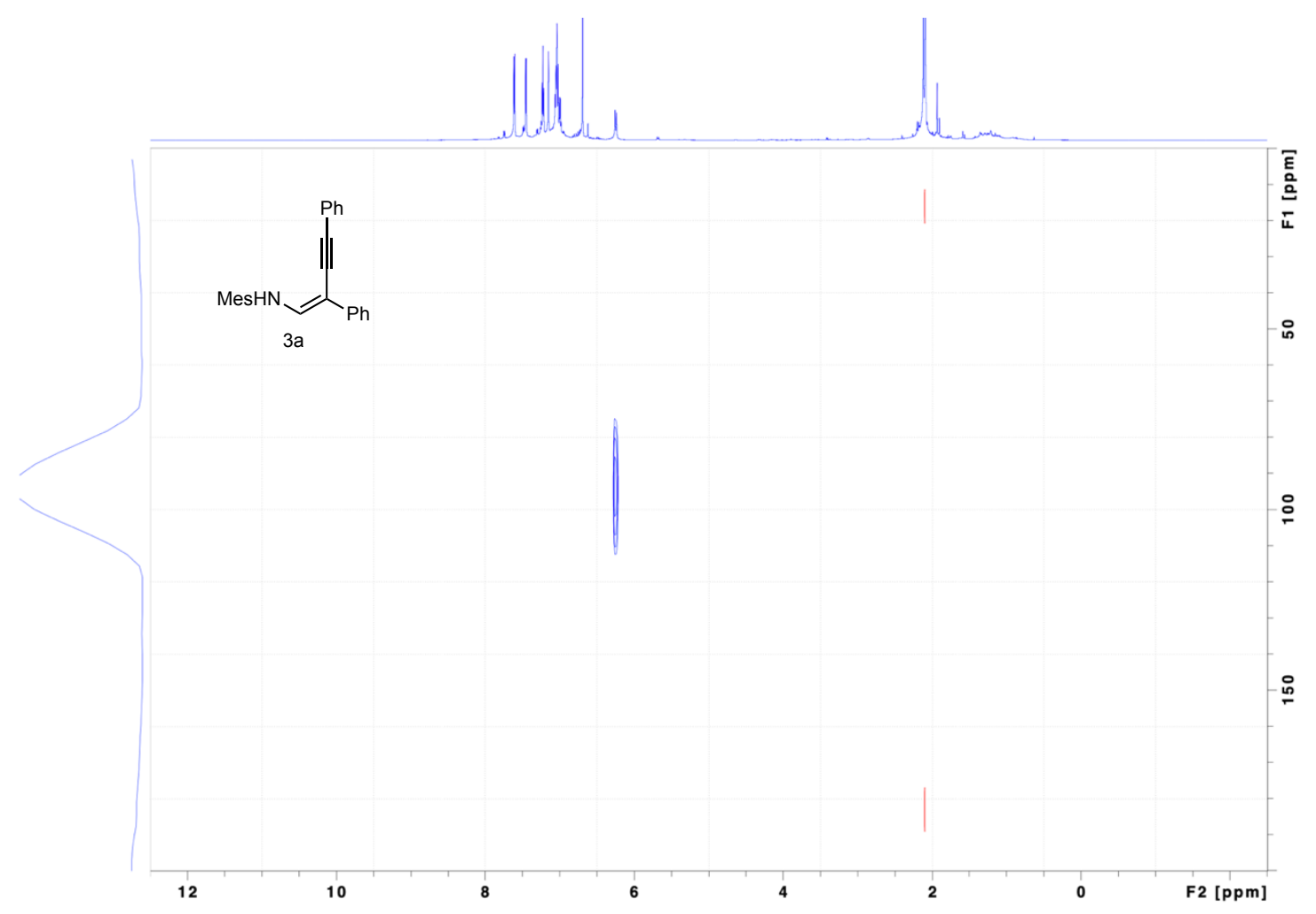

Figure S14. ${ }^{1} \mathrm{H}-{ }^{15} \mathrm{~N} \mathrm{HSQC}$ of $3 \mathrm{a}\left(700 \mathrm{MHz}, \mathrm{C}_{6} \mathrm{D}_{6}\right)$

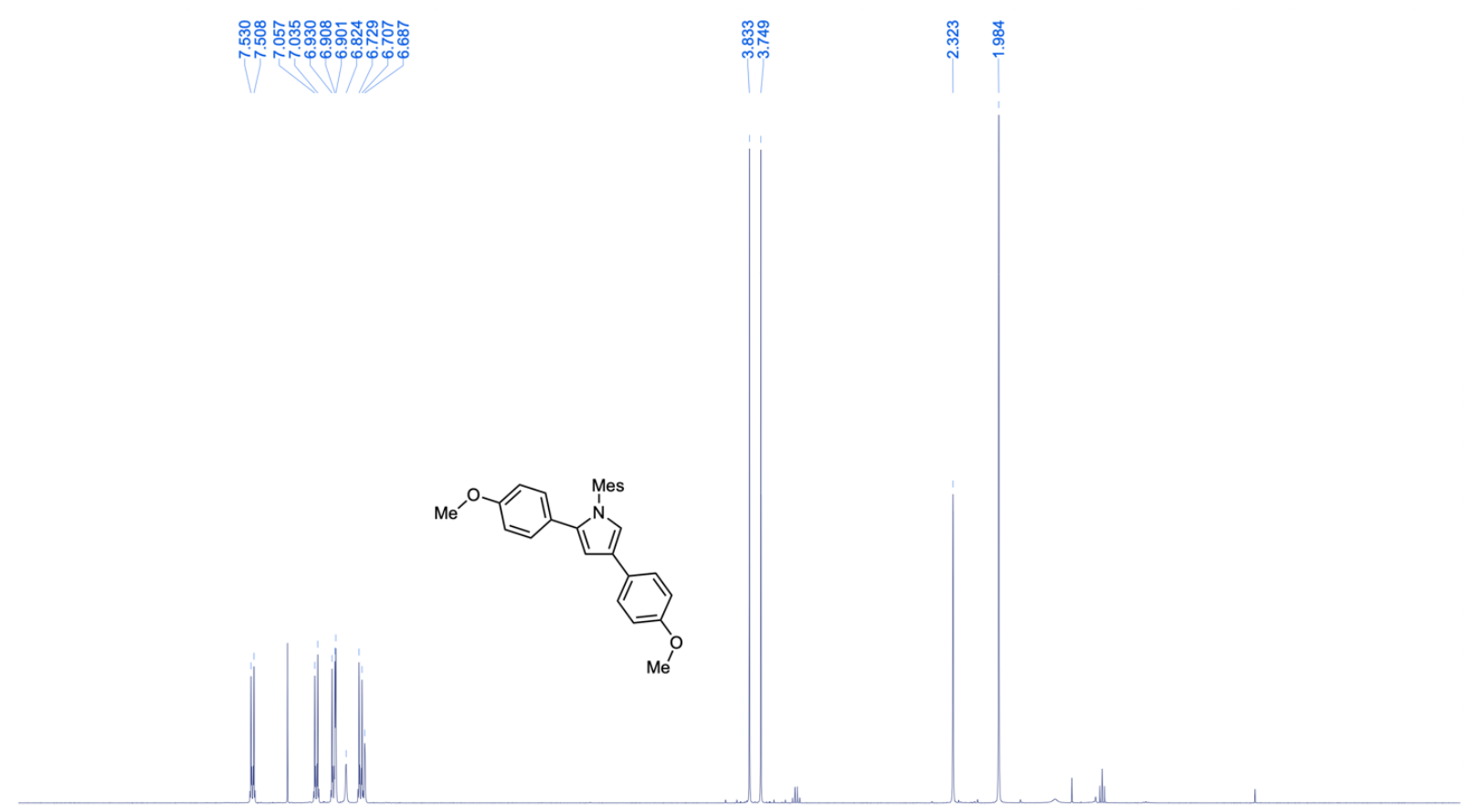

Figure S15. ${ }^{1} \mathrm{H} \quad \mathrm{NMR}$ of 1-mesityl-2,4-bis(4-methoxyphenyl)-1H-pyrrole (400 MHz, $\left.\mathrm{CDCl}_{3}\right)$ 


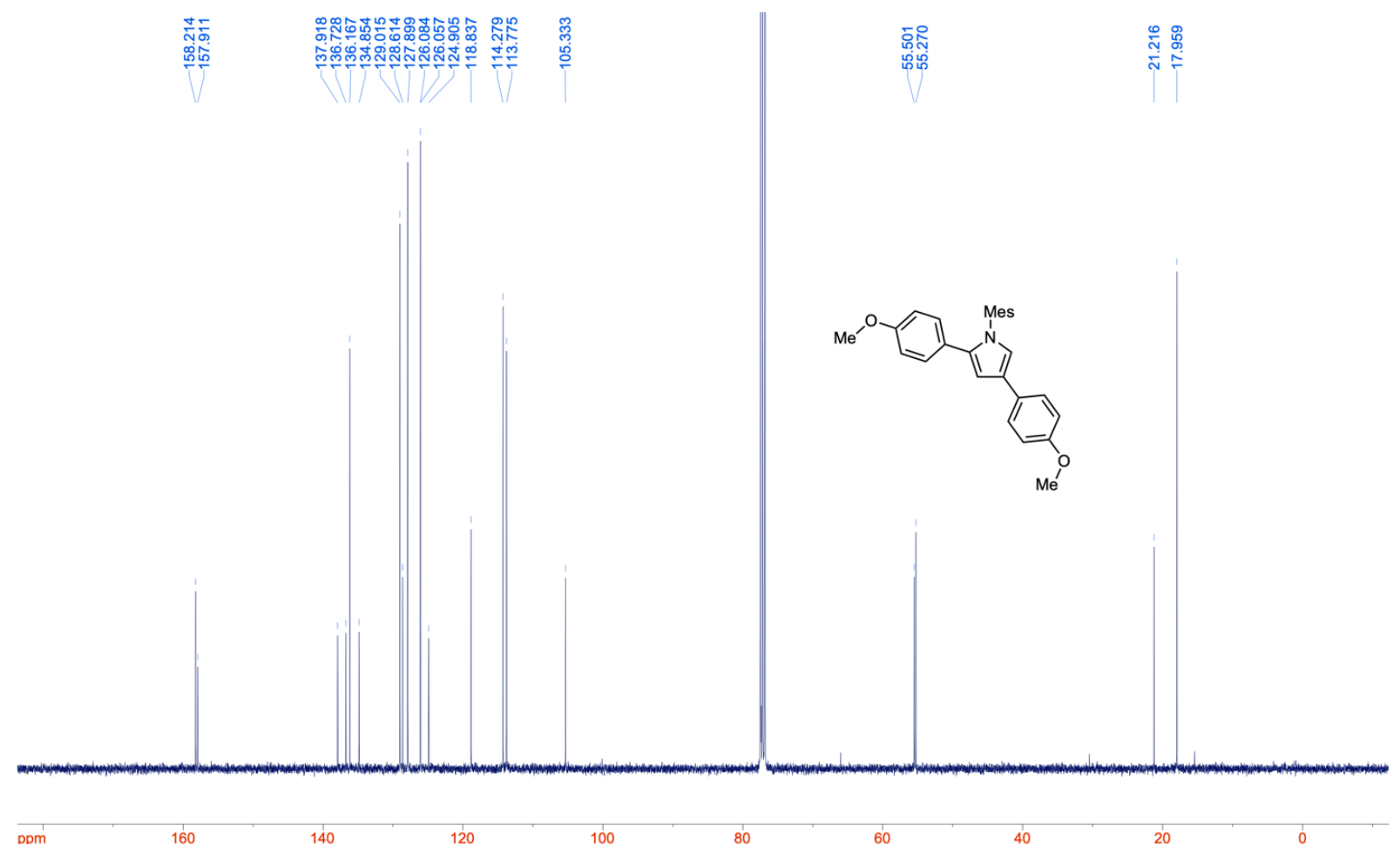

Figure S16. ${ }^{13} \mathrm{C}$ NMR of 1-mesityl-2,4-bis(4-methoxyphenyl)-1H-pyrrole $(100 \mathrm{MHz}$, $\left.\mathrm{CDCl}_{3}\right)$

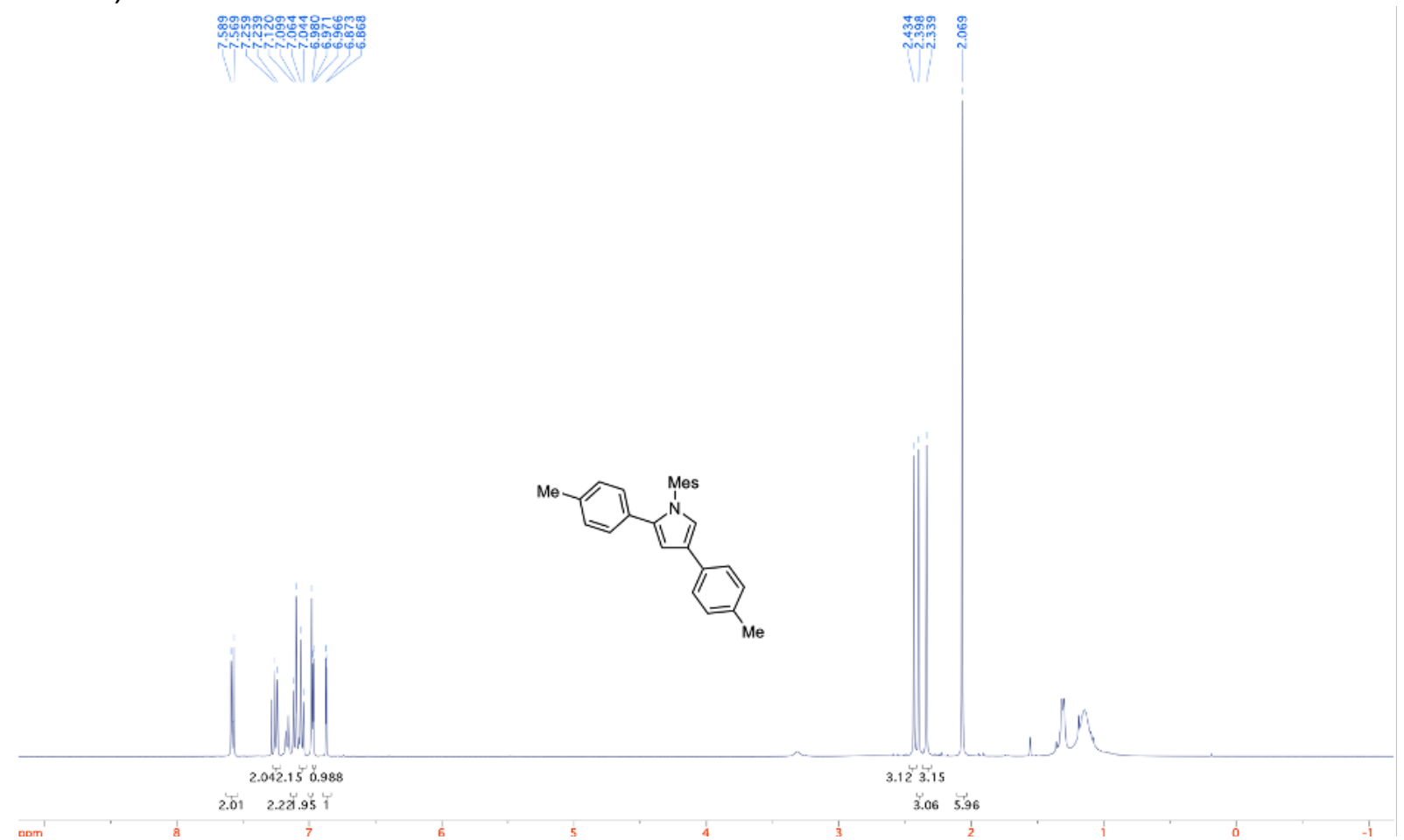

Figure S17. ${ }^{1} \mathrm{H}$ NMR of 1-mesityl-2,4-bis(4-tolyl)-1H-pyrrole $\left(400 \mathrm{MHz}, \mathrm{CDCl}_{3}\right)$ 

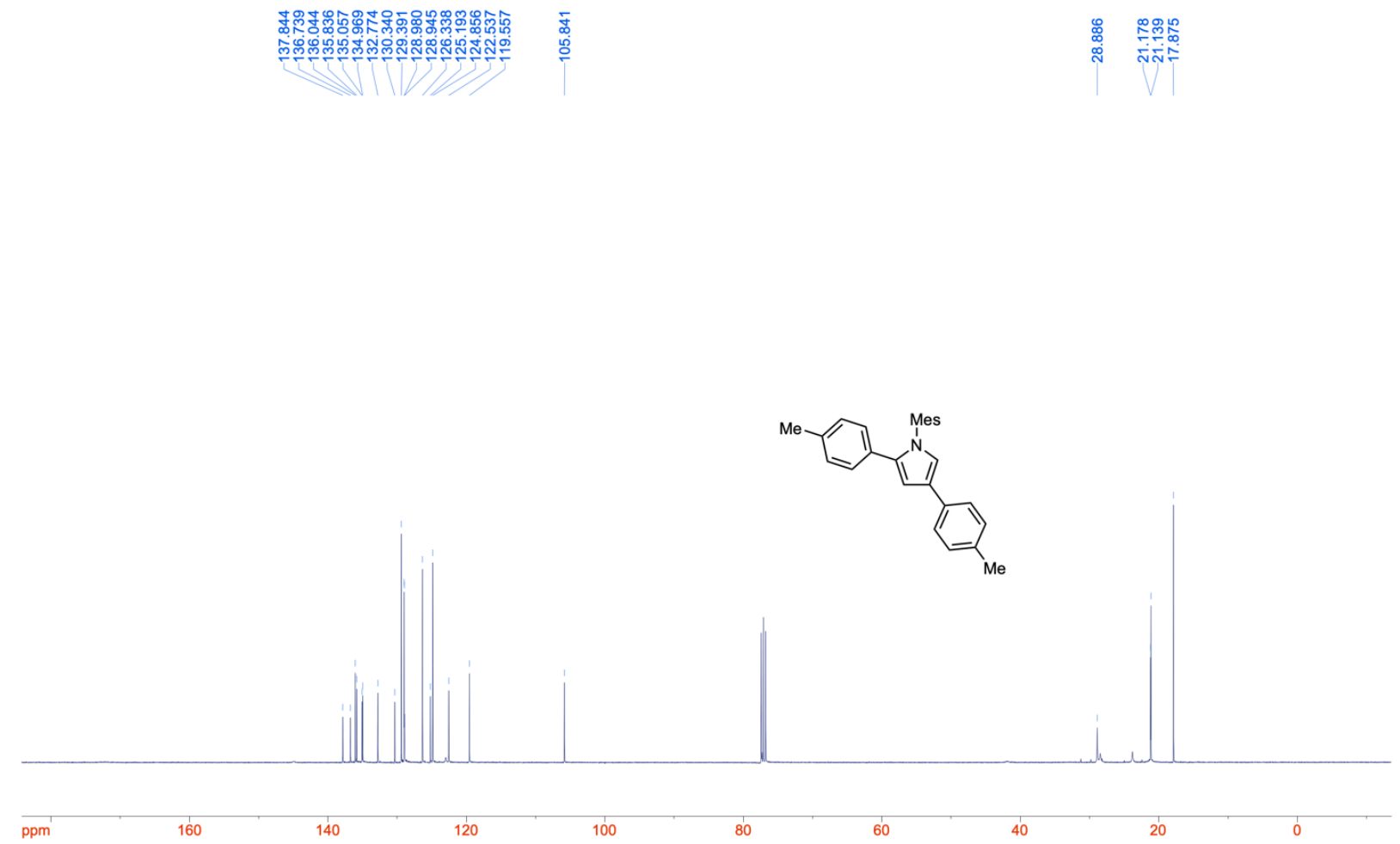

Figure S18. ${ }^{13} \mathrm{C}$ NMR of 1-mesityl-2,4-bis(4-tolyl)-1H-pyrrole $\left(100 \mathrm{MHz}, \mathrm{CDCl}_{3}\right)$

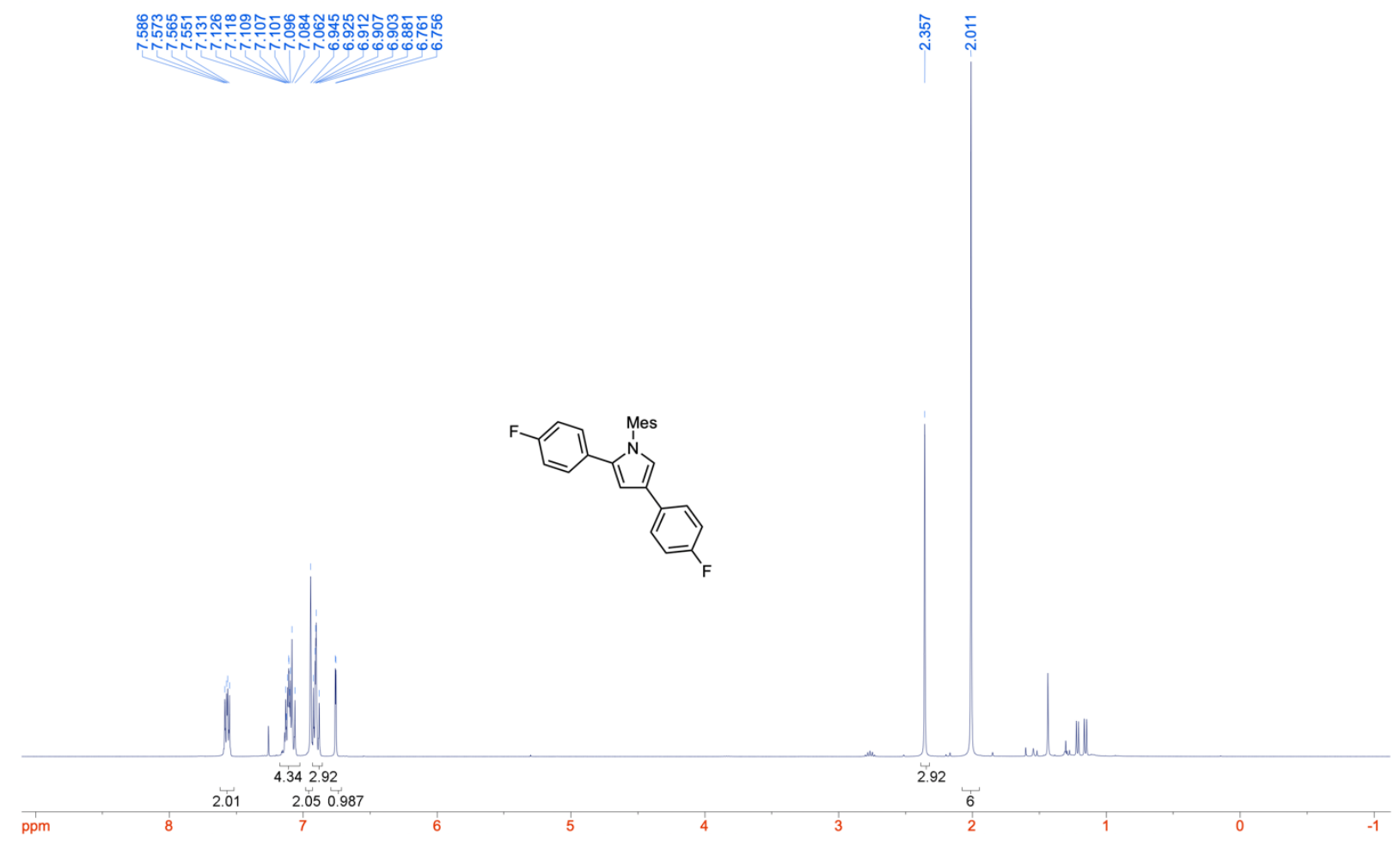

Figure S19. ${ }^{1} \mathrm{H}$ NMR of 1-mesityl-2,4-bis(4-fluorophenyl)-1H-pyrrole $\left(400 \mathrm{MHz}, \mathrm{CDCl}_{3}\right)$ 


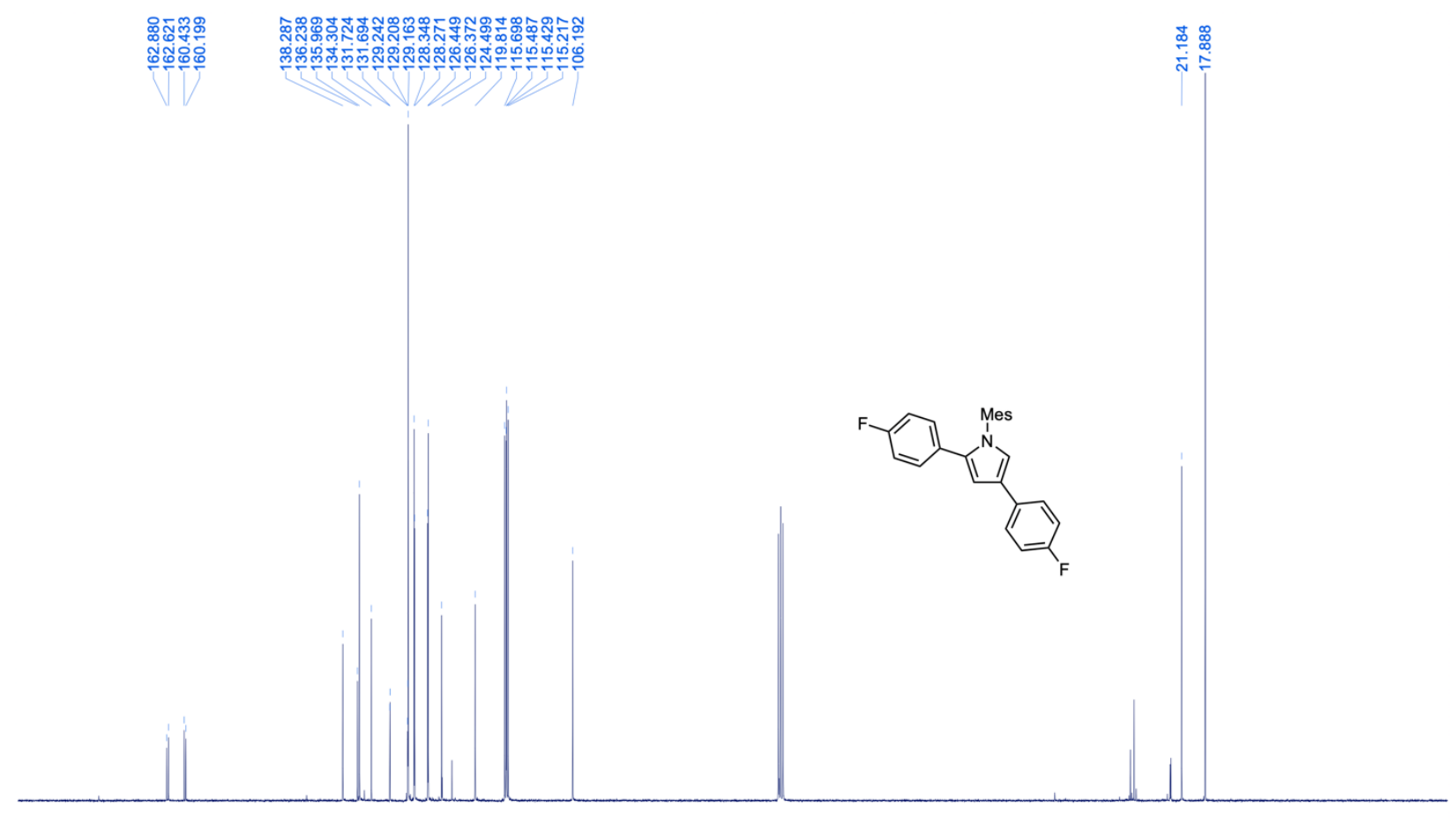

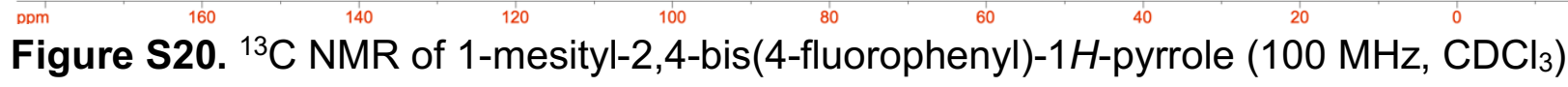

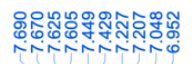

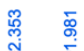

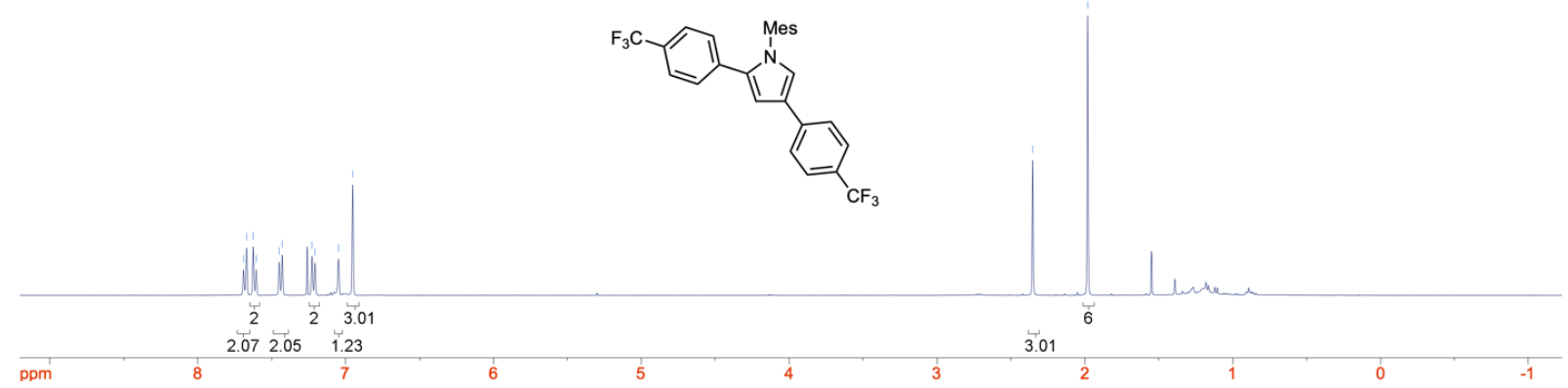

Figure S21. ${ }^{1} \mathrm{H}$ NMR of 1-mesityl-2,4-bis(4-trifluoromethylphenyl)-1 $\mathrm{H}$-pyrrole $(400 \mathrm{MHz}$, $\left.\mathrm{CDCl}_{3}\right)$ 


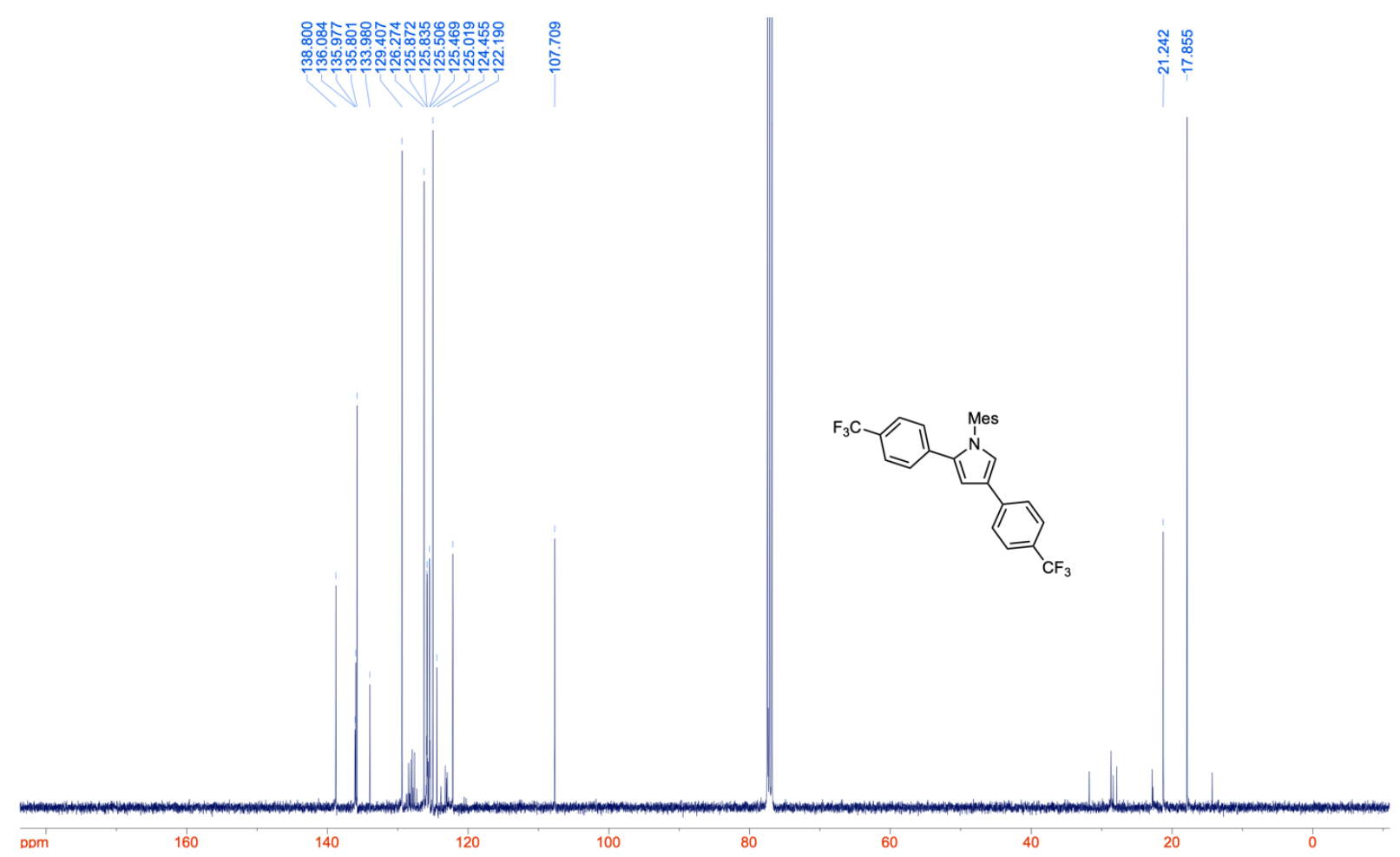

Figure S22. ${ }^{13} \mathrm{C}$ NMR of 1-mesityl-2,4-bis(4-trifluoromethylphenyl)-1H-pyrrole (100 $\mathrm{MHz}, \mathrm{CDCl}_{3}$ )

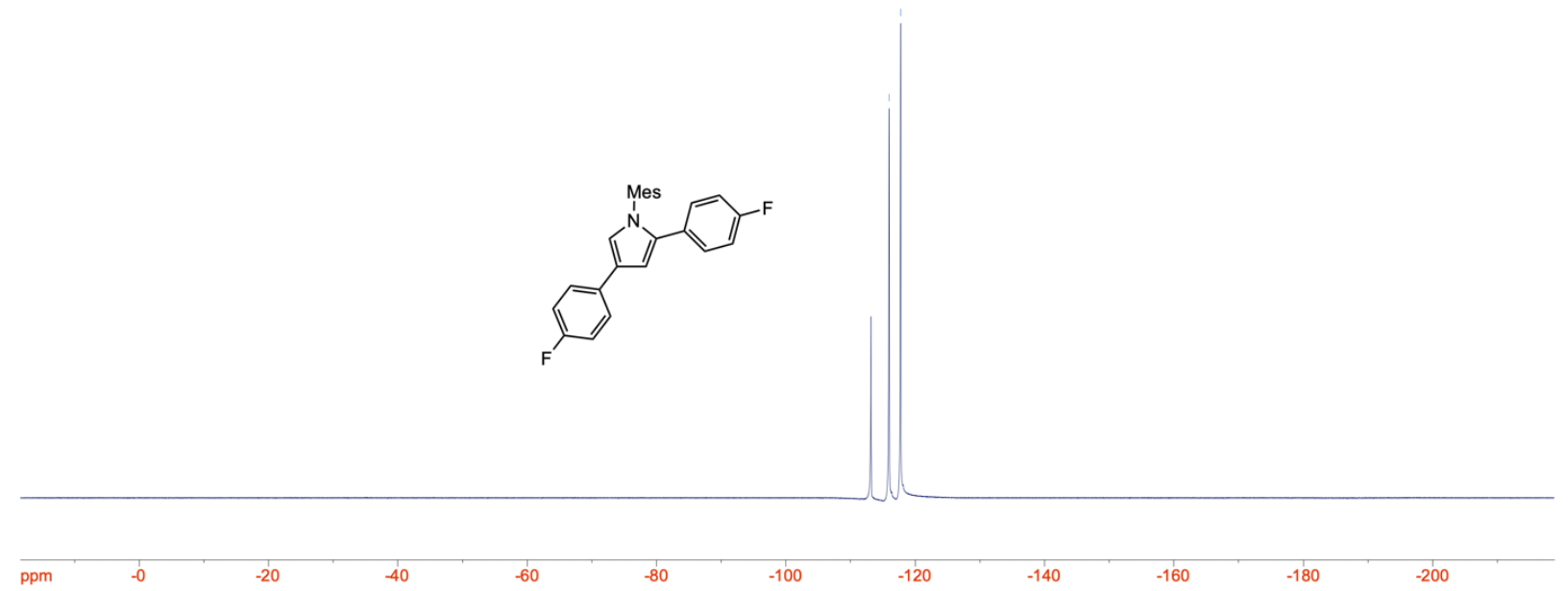

Figure S23. ${ }^{19} \mathrm{~F}$ NMR of 1-mesityl-2,4-bis(4-fluorophenyl)-1H-pyrrole $\left(376 \mathrm{MHz}, \mathrm{CDCl}_{3}\right)$ 


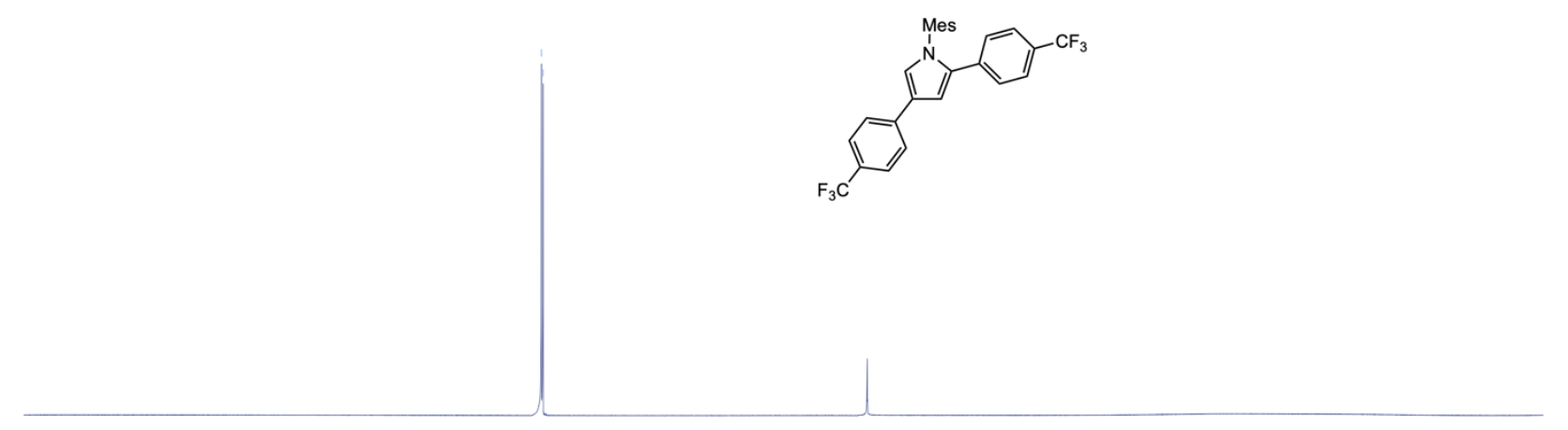

Figure S24. ${ }^{19} \mathrm{~F}$ NMR of 1-mesityl-2,4-bis(4-trifluoromethylphenyl)-1H-pyrrole $(376 \mathrm{MHz}$ $\mathrm{CDCl}_{3}$ )

\section{IR Spectra.}

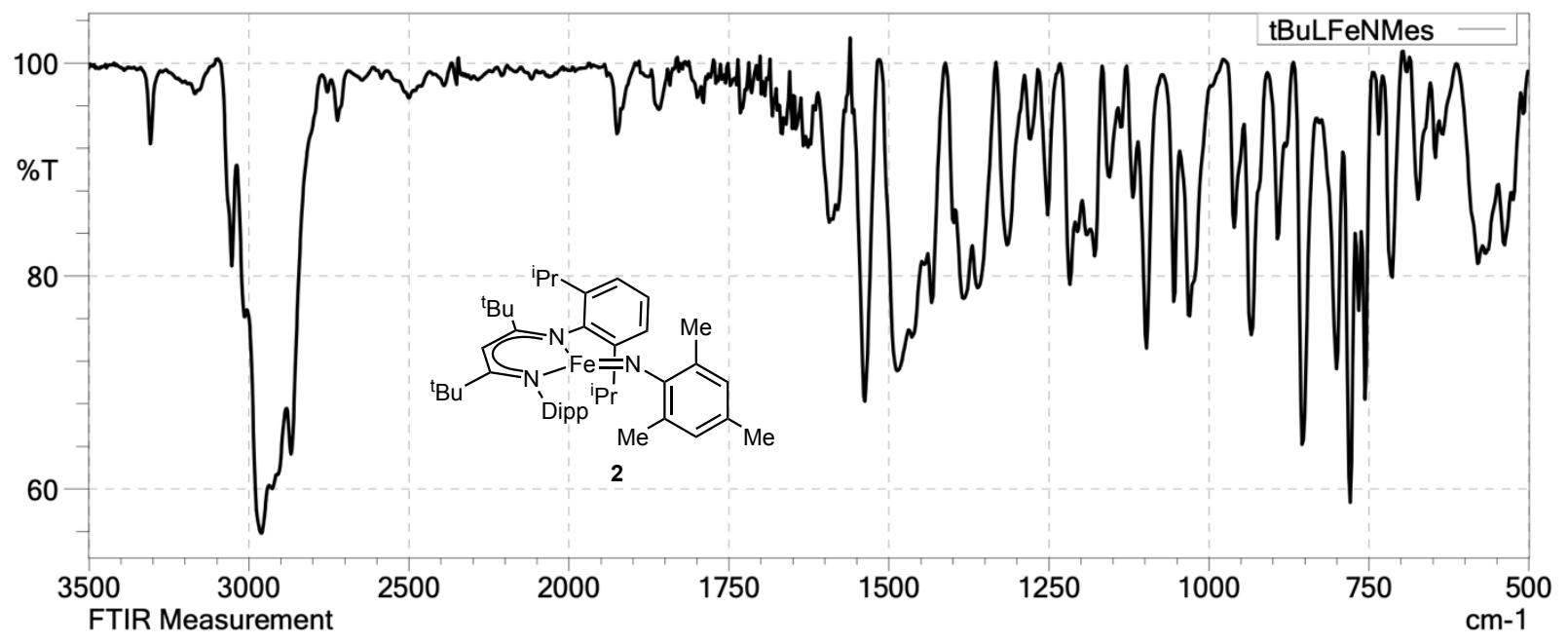

Figure S25. IR Spectrum of tBuLFeNMes (2). 


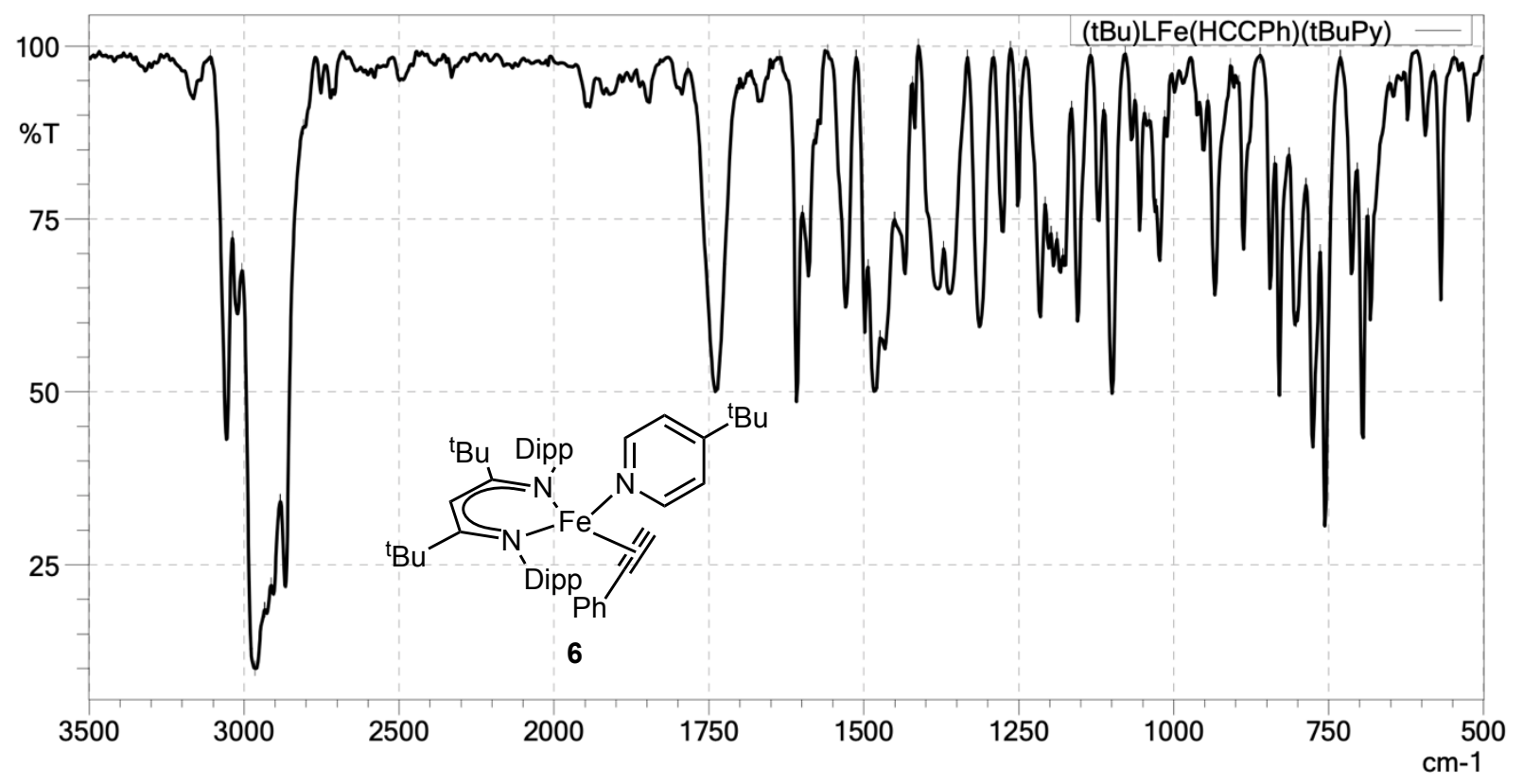

Figure S26. IR Spectrum of ${ }^{\mathrm{B} u} \mathrm{LFe}(\mathrm{HCCPh})(\mathrm{B} B \mathrm{Py})(\mathbf{6})$.

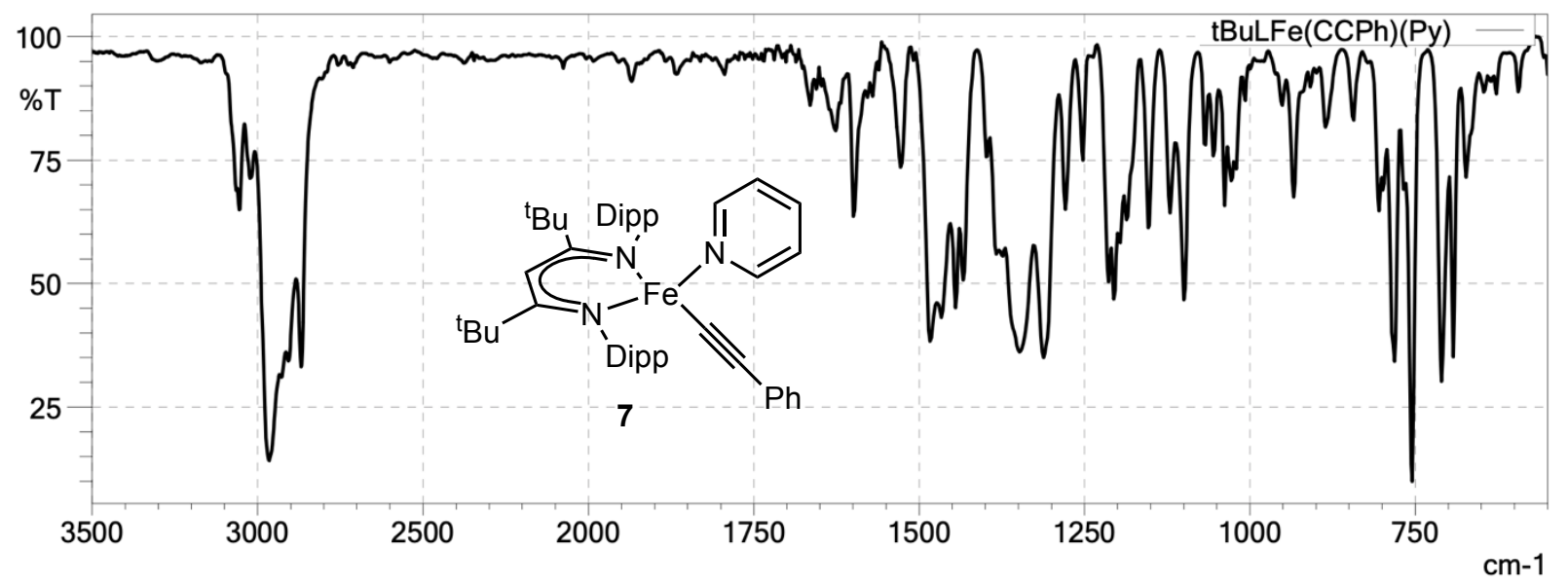

Figure S27. IR Spectrum of tBuLFeCCPh(Py) (7). 
VII. UV-Vis Spectra.

UV-Vis Spectrum of ${ }^{\text {tBu }}$ LFeNMes (2)

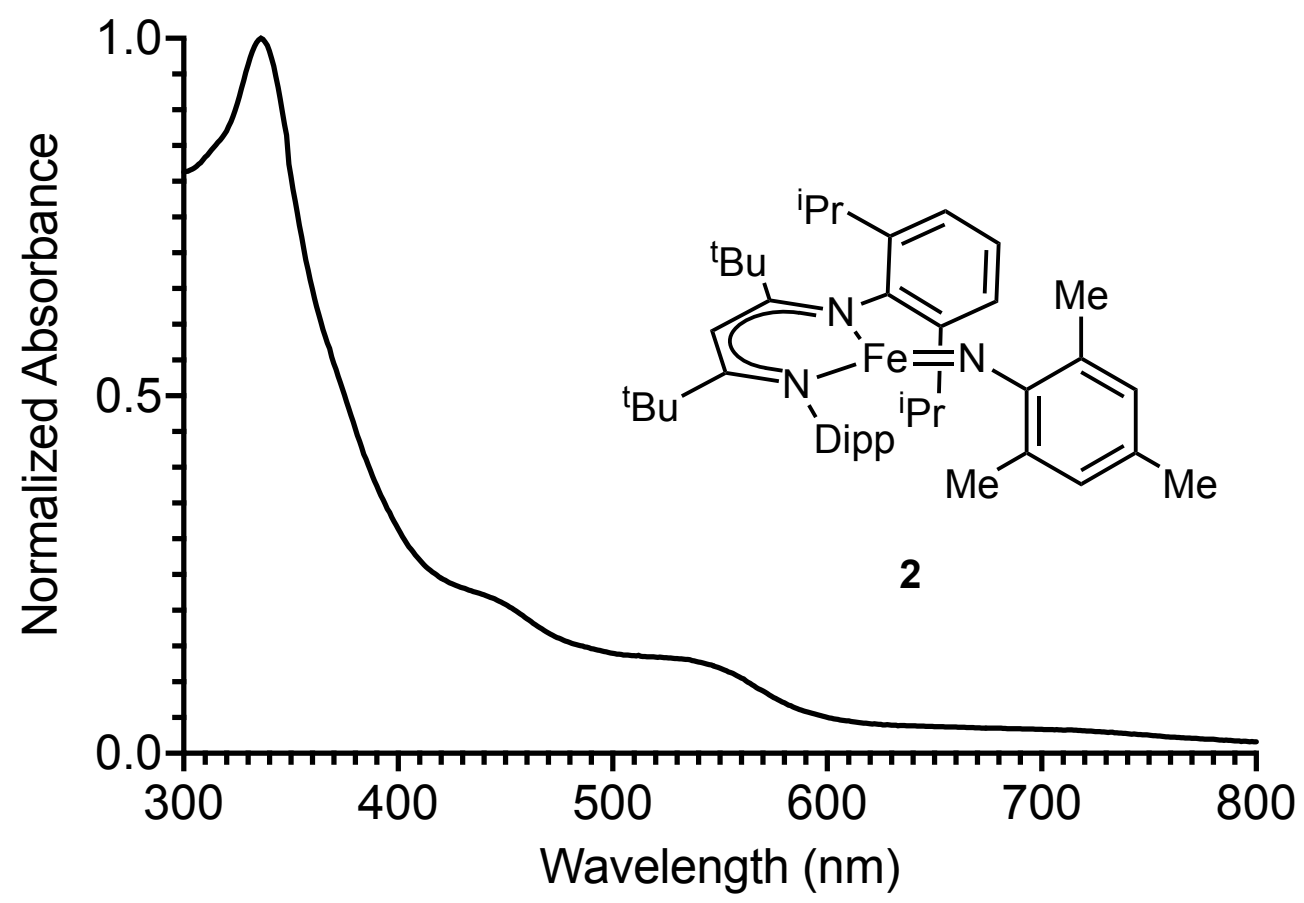

Figure S28. UV-Vis Spectrum of tBuLFeNMes (2).

UV-Vis Spectrum of ${ }^{\mathrm{B} u} \mathrm{LFe}(\mathrm{HCCPh})\left({ }^{\mathrm{t} B u P y}\right)(\mathbf{6})$

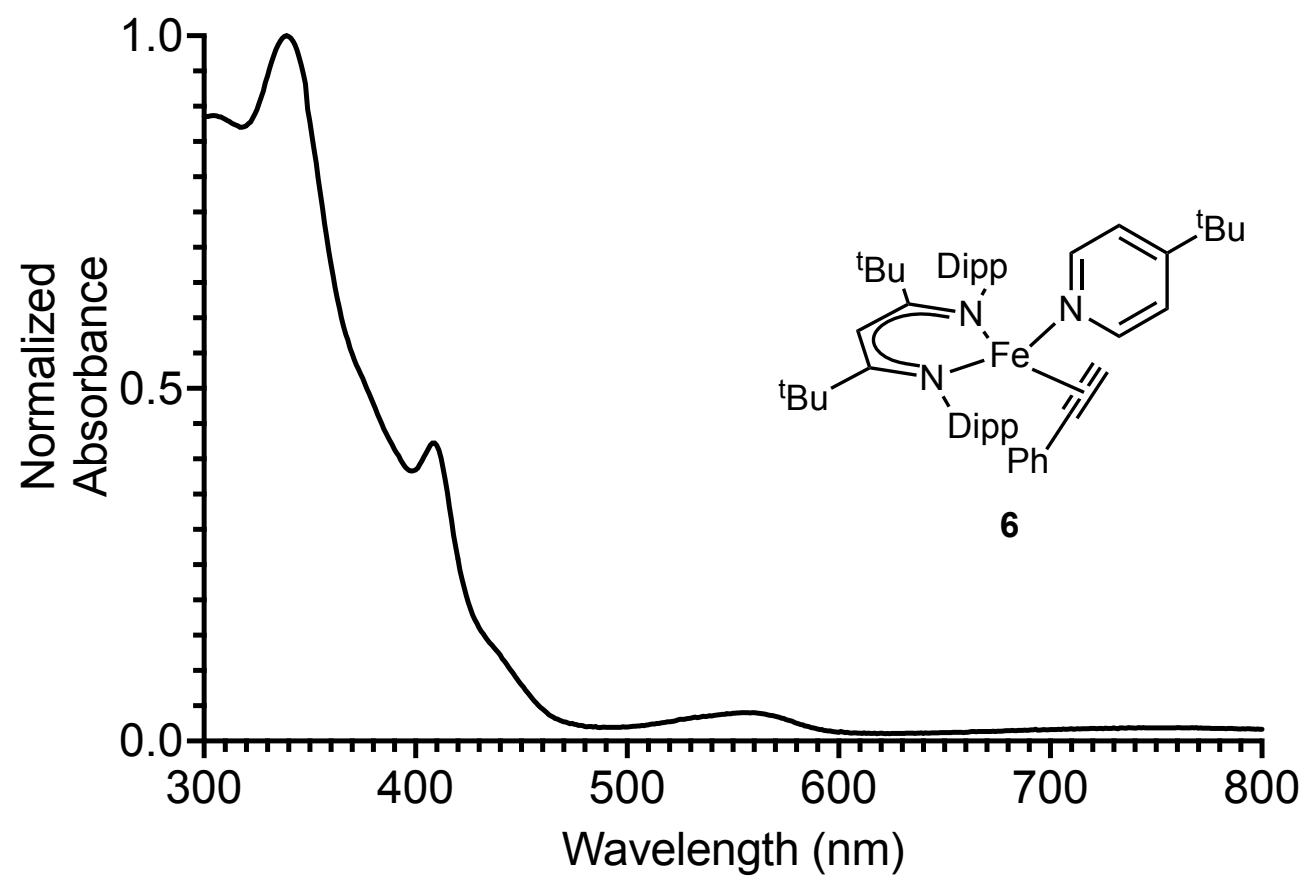

Figure S29. UV-Vis Spectrum of ${ }^{\mathrm{tBu}} \mathrm{LFe}(\mathrm{HCCPh})\left({ }^{\mathrm{t} B u P y}\right)(\mathbf{6})$. 


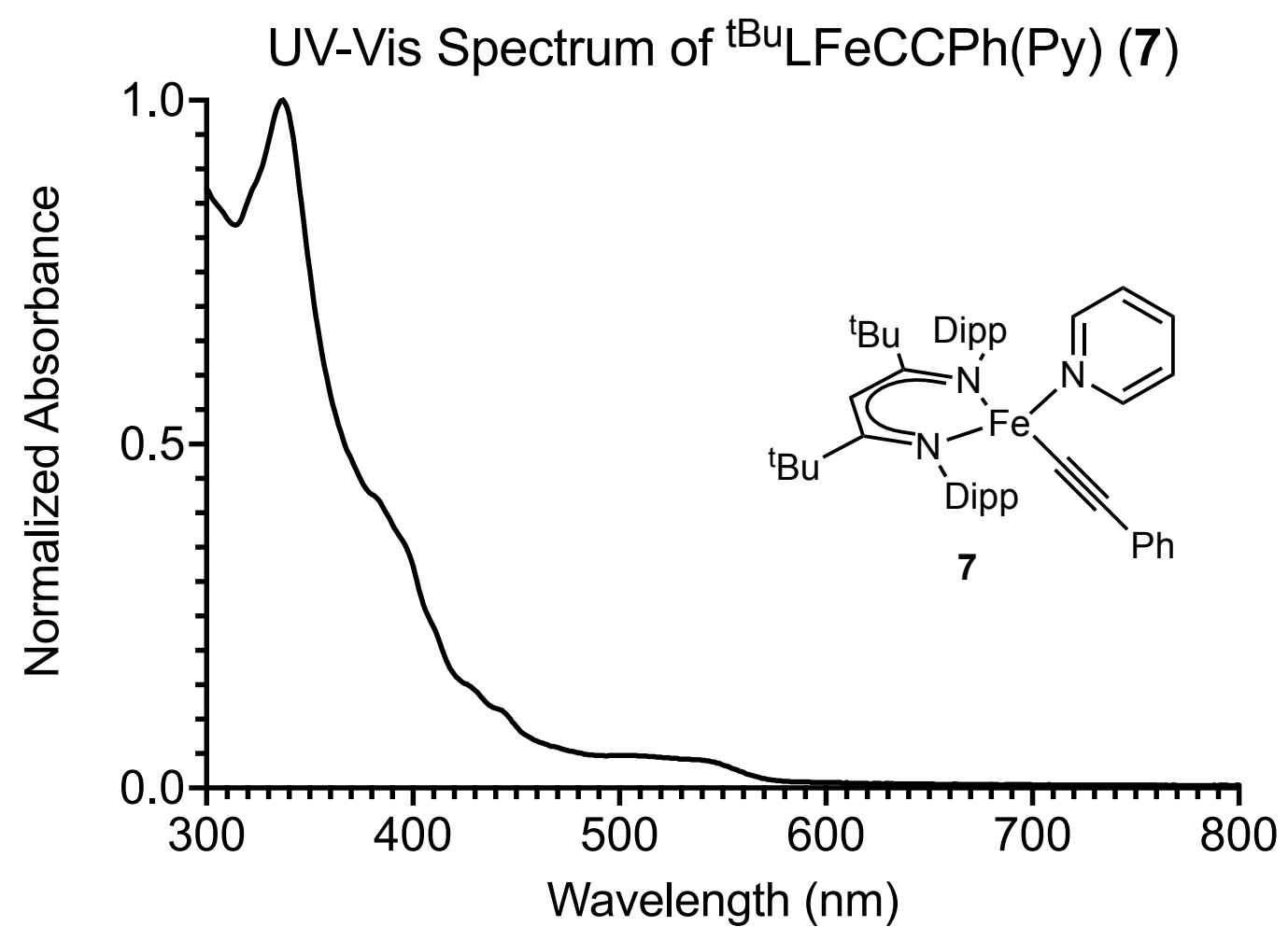

Figure S30. UV-Vis Spectrum of tBuLFeCCPh(Py) (7).

VIII. Crystallographic Data.

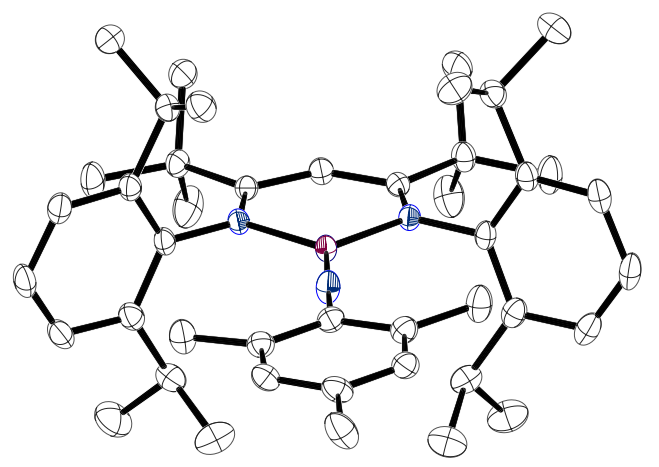

Figure S31. Solid state molecular structure of tBuLFeNMes (2) at $50 \%$ probability ellipsoids. Hydrogen atoms removed for clarity. 


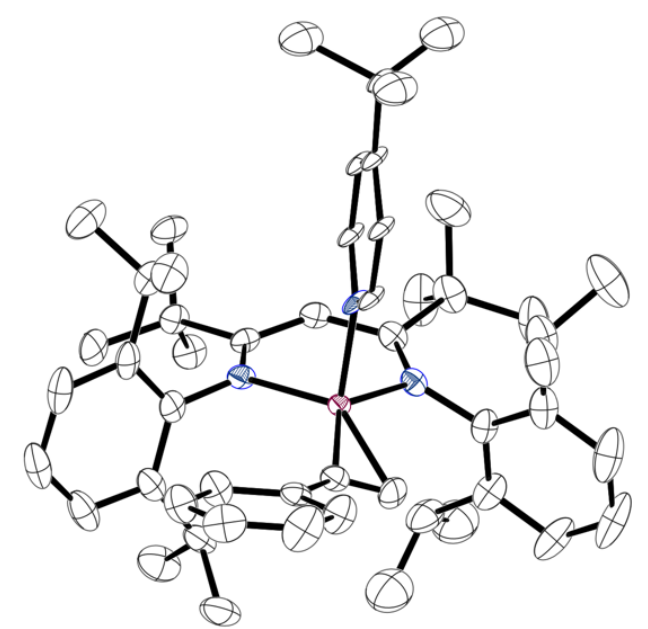

Figure S32. Solid state molecular structure of ${ }^{\mathrm{tBu}} \mathrm{LFe}(\mathrm{HCCPh})\left({ }^{\mathrm{t} B u P y}\right)$ (6) at $50 \%$ probability ellipsoids. Hydrogen atoms removed for clarity.

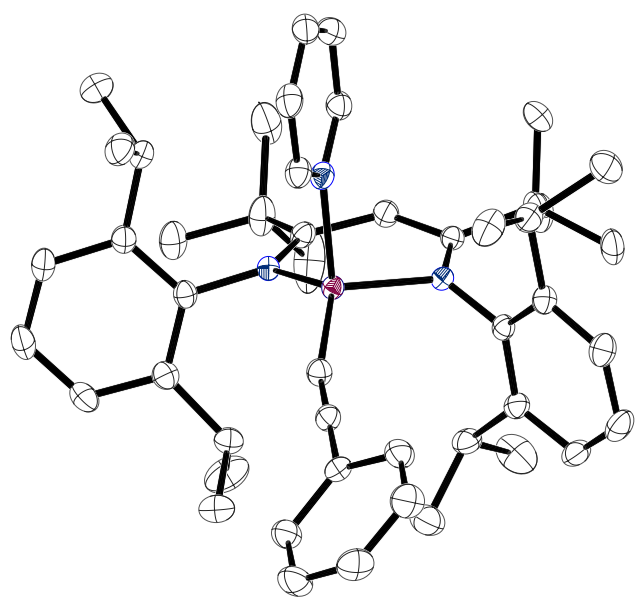

Figure S33. Solid state molecular structure of ${ }^{\mathrm{tBu}} \mathrm{LFeCCPh}(\mathrm{Py})(7)$ at $50 \%$ probability ellipsoids. Hydrogen atoms removed for clarity.

Table S2. Crystal data and structure refinement for 2, 6 and 7.

tBu LFeNMes (2) $\quad{ }^{\text {tBu }} \mathrm{LFe}(\mathrm{HCCPh})(\mathrm{BBPy})(\mathbf{6}){ }^{\mathrm{tBu}} \mathrm{LFeCCPh}(\mathrm{Py})(\mathbf{7})$

\begin{tabular}{llll}
\hline Empirical formula & $\mathrm{C}_{44} \mathrm{H}_{64} \mathrm{FeN}_{3}$ & $\mathrm{C}_{52} \mathrm{H}_{72} \mathrm{FeN}_{3}$ & $\mathrm{C}_{101} \mathrm{H}_{138} \mathrm{Fe}_{2} \mathrm{~N}_{6}$ \\
Formula weight & 690.83 & 794.97 & 1547.87 \\
Temperature $(\mathrm{K})$ & $108(2)$ & $100(2)$ & $102(2)$ \\
Wavelength $(\AA)$ & 1.54178 & 0.71073 & 1.54178 \\
Crystal system & Monoclinic & Triclinic & Monoclinic \\
Space group & $\mathrm{P} 2{ }_{1} / \mathrm{c}$ & $\mathrm{P}-1$ & $\mathrm{P} 2_{1} / \mathrm{c}$
\end{tabular}




\begin{tabular}{|c|c|c|c|}
\hline \multicolumn{4}{|l|}{ Unit cell dimensions } \\
\hline $\mathrm{a}(\AA)$ & $17.1442(4)$ & $10.6252(13)$ & $13.2575(3)$ \\
\hline $\mathrm{b}(\AA)$ & $10.5151(2)$ & $12.0832(14)$ & $11.8388(3)$ \\
\hline$c(\AA)$ & $22.3213(5)$ & $20.923(3)$ & $29.6445(6)$ \\
\hline$\alpha\left({ }^{\circ}\right)$ & 90 & $77.672(5)$ & 90 \\
\hline$\beta\left(\left(^{\circ}\right)\right.$ & $97.3929(10)$ & $75.724(5)$ & $99.9512(10)$ \\
\hline$Y\left({ }^{\circ}\right)$ & 90 & $68.510(5)$ & 90 \\
\hline Volume $\left(\AA^{3}\right)$ & $3990.48(15) 3$ & $2399.6(5)$ & $4582.79(18)$ \\
\hline Z & 4 & 2 & 2 \\
\hline $\begin{array}{l}\text { Density (calculated) } \\
\mathrm{Mg} /\left(\mathrm{m}^{3}\right)\end{array}$ & 1.15 & 1.1 & 1.122 \\
\hline $\begin{array}{l}\text { Absorption coefficient } \\
\left(\mathrm{mm}^{-1}\right)\end{array}$ & 3.259 & 0.349 & 2.889 \\
\hline$F(000)$ & 1500 & 862 & 1676 \\
\hline Crystal size $\left(\mathrm{mm}^{3}\right)$ & $0.141 \times 0.111 \times 0.095$ & $0.539 \times 0.505 \times 0.403$ & $0.222 \times 0.061 \times 0.046$ \\
\hline $\begin{array}{l}\theta \text { range for data } \\
\text { collection }\left({ }^{\circ}\right)\end{array}$ & 2.599 to 74.507 & 2.096 to 27.750 & 3.027 to 74.532 \\
\hline Index ranges & $\begin{array}{l}-20 \leq \mathrm{h} \leq 21,-12 \leq \mathrm{k} \leq 13,- \\
27 \leq \mathrm{I} \leq 27\end{array}$ & $\begin{array}{l}-13 \leq h \leq 13,-15 \leq k \leq 15,- \\
27 \leq 1 \leq 27\end{array}$ & $\begin{array}{l}-16 \leq h \leq 16,-12 \leq k \leq 14,- \\
36 \leq 1 \leq 37\end{array}$ \\
\hline Reflections collected & 51961 & 39402 & 78737 \\
\hline $\begin{array}{l}\text { Independent } \\
\text { reflections }\end{array}$ & $8151[R($ int $)=0.0322]$ & $22407[R($ int $)=0.079]$ & $9351[R($ int $)=0.049]$ \\
\hline $\begin{array}{l}\text { Completeness to } \\
\text { theta }\end{array}$ & $\begin{array}{l}100.00 \% \\
\left(\theta=67.679^{\circ}\right)\end{array}$ & $\begin{array}{l}98.90 \% \\
\left(\theta=25.242^{\circ}\right)\end{array}$ & $\begin{array}{l}100.00 \% \\
\left(\theta=67.679^{\circ}\right)\end{array}$ \\
\hline Absorption correction & $\begin{array}{l}\text { Semi-empirical from } \\
\text { equivalents }\end{array}$ & $\begin{array}{l}\text { Semi-empirical from } \\
\text { equivalents }\end{array}$ & $\begin{array}{l}\text { Semi-empirical from } \\
\text { equivalents }\end{array}$ \\
\hline $\begin{array}{l}\text { Max. and min. } \\
\text { transmission }\end{array}$ & 0.7246 and 0.6542 & 0.8878 and 0.7867 & 0.6627 and 0.4782 \\
\hline
\end{tabular}




\begin{tabular}{|c|c|c|c|}
\hline Refinement method & $\begin{array}{l}\text { Full-matrix least- } \\
\text { squares on F2 }\end{array}$ & $\begin{array}{l}\text { Full-matrix least-squares } \\
\text { on F2 }\end{array}$ & $\begin{array}{l}\text { Full-matrix least- } \\
\text { squares on F2 }\end{array}$ \\
\hline $\begin{array}{l}\text { Data / restraints / } \\
\text { parameters }\end{array}$ & $8151 / 0 / 450$ & 22407 / 2 / 496 & $9351 / 21 / 515$ \\
\hline Goodness-of-fit on $\mathrm{F}^{2}$ & 1.054 & 1.142 & 1.028 \\
\hline $\begin{array}{l}\text { Final } R \text { indices } \\
{[I>2 \sigma(I)]}\end{array}$ & $\begin{array}{l}\mathrm{R} 1=0.0278, w R 2= \\
0.0754\end{array}$ & $\begin{array}{l}\mathrm{R} 1=0.1000, w \mathrm{R} 2= \\
0.2311\end{array}$ & $\begin{array}{l}\mathrm{R} 1=0.0339, \mathrm{wR} 2= \\
0.0873\end{array}$ \\
\hline $\mathrm{R}$ indices (all data) & $\begin{array}{l}\mathrm{R} 1=0.0319, \mathrm{wR} 2= \\
0.0777\end{array}$ & $\begin{array}{l}\mathrm{R} 1=0.1159, \mathrm{wR} 2= \\
0.2403\end{array}$ & $\begin{array}{l}\mathrm{R} 1=0.0365, \mathrm{wR} 2= \\
0.0889\end{array}$ \\
\hline $\begin{array}{l}\text { Largest diff. peak and } \\
\text { hole }\left(e \cdot A^{-3}\right)\end{array}$ & 0.274 and -0.282 & 0.972 and -0.705 & 0.311 and -0.547 \\
\hline Extinction Coefficient & $\mathrm{n} / \mathrm{a}$ & $0.060(7)$ & $\mathrm{n} / \mathrm{a}$ \\
\hline
\end{tabular}




\section{References.}

1. Chiang, K. P.; Holland, P. L.; Adhikari, D.; Mindiola, D. J. Iron 2,2,6,6-tetramethyl-3,5-bis(2,6-diisopropylphenylimido)heptyl chloride (LtBu,iPr2FeCl). Inorg. Synth. 2010, 35, 41-43.

2. Smith, J. M.; Sadique, A. R.; Cundari, T. R.; Rodgers, K. R.; Lukat-Rodgers, G.; Lachicotte, R. J.; Flaschenriem, C. J.; Vela, J.; Holland, P. L. Studies of low-coordinate iron dinitrogen complexes. J. Am. Chem. Soc. 2006, 128, 756-69.

3. Stoian, S. A.; Yu, Y.; Smith, J. M.; Holland, P. L.; Bominaar, E. L.; Munck, E. Mossbauer, electron paramagnetic resonance, and crystallographic characterization of a high-spin $\mathrm{Fe}(\mathrm{I})$ diketiminate complex with orbital degeneracy. Inorg. Chem. 2005, 44, 4915-4922.

4. Eckert, N. A.; Smith, J. M.; Lachicotte, R. J.; Holland, P. L. Low-coordinate iron(II) amido complexes of beta-diketiminates: synthesis, structure, and reactivity. Inorg. Chem. 2004, 43, 3306-3321.

5. Kwok, S. W.; Fotsing, J. R.; Fraser, R. J.; Rodionov, V. O.; Fokin, V. V. Transition-metal-free catalytic synthesis of 1,5-diaryl-1,2,3-triazoles. Org. Lett. 2010, 12, 4217-4219.

6. Ottmers, D. M.; Rase, H. F. Potassium graphites prepared by mixed-reaction technique. Carbon 1966, 4, 125-127.

7. Stollenz, M.; Barbasiewicz, M.; Nawara-Hultzsch, A. J.; Fiedler, T.; Laddusaw, R. M.; Bhuvanesh, N.; Gladysz, J. A. Dibridgehead diphosphines that turn themselves inside out. Angew. Chem., Int. Ed. 2011, 50, 6647-6651.

8. Bruker Analytical X-Ray, Madison, WI, 2020.

9. Sheldrick, G. M. A short history of SHELX. Acta. Crystallogr. A 2008, 64 (Pt 1), 112-122.

10. Dolomanov, O. V.; Bourhis, L. J.; Gildea, R. J.; Howard, J. A. K.; Puschmann, H. OLEX2: a complete structure solution, refinement and analysis program. J. Appl. Crystallogr. 2009, 42, 339-341.

11. Cowley, R. E.; Eckert, N. A.; Vaddadi, S.; Figg, T. M.; Cundari, T. R.; Holland, P. L. Selectivity and mechanism of hydrogen atom transfer by an isolable imidoiron(III) complex. J. Am. Chem. Soc. 2011, 133, 9796-9811.

12. Fleige, M.; Glorius, F. alpha-Unsubstituted Pyrroles by NHC-Catalyzed Three-Component Coupling: Direct Synthesis of a Versatile Atorvastatin Derivative. Chem. Eur. J. 2017, 23, 10773-10776. 